\title{
مشكلات توافق الأيتام ذوي الظروف الخاصة مع الأسر الحاضنة \\ (دراسة مطبقة على الأسر الحاضنة في المدينة المنورة)
}

\section{Compatibility Problems among The Orphans of Special Conditions within Their Foster Families (A study Applied to Foster Families in Medina)}

\section{إعداد الباحث/ عجمي غنيزان المطيري}

ماجستير في التوجيه و الإصلاح الأسري، كلية الآداب و العلوم الإنسانية، جامعة الملك عبد العزيز، المملكة العربية السعودية

هدفت الدر اسة إلى قياس التو افق النفسي و الاجتماعي لدى الأيتام ذوي الظروف الخاصة من وجهة نظر الأسر الكافلـة التابعين لإدارة الأسر الكافلـة بالمدينـة المنـورة، بالإضـافة إلى التعرف على الاختلاف في التو افق النفسي والاجتمـاعي للأيتـام ذوي الظروف الخاصة من وجهة نظر الأسر الكافلة لهم، تكونت عينة الدراسة من (99) أسرة، تم اختبار هم بالطريقة العشو ائية من مجتمع الدر اسة الأصلي وبلغت نسبتهم (16.5٪)، استخدم الباحث المنهج الوصفي المسحي ومن الأدوات التي اعتمد الباحث عليها في تحقيق أهداف الدراسة، استبانة مشكلات التو افق النفسي و الاجتمـاعي إعداد/ الباحث تكونت الاستبانة من مجموعة من العبار ات و عددها (30) عبارة تشـمل محورين مشكلات التو افق النفسي و الاجتماعي للأيتام ذوي الظروف الخاصـة من وجهة نظر الأسر الكافلة بالمدينة المنورة، توصلت الدر اسـة إلى عدد من النتائج من أهمها: ارتفاع المنوسطات لعدد من العبار ات للمحور الأول (التوافق النفسي) و التي تمثلت على الترتيب كالتالي: شعور الطفل بالدفء و الحمايـة والانتماء، الثقة بالنفس كبيرة وعالية بأفر اد الأسرة. بينما جاء المحور الثاني (النت افق الاجتماعي) عبار اته المتمثلة في الارتفاع، كالتالي: تميز الطفل باكتسابه لمهار ات مع أقر انه. لا يوجد فروق دالة احصائية بين فقرات عبار ات المحور الأول (مشكلات التو افق النفسي و الدرجة الكلية) بين الذكور والإنات من الأسر الكافلة في استجاباتهم لهذه العبارة. وجود فروق ذات دلالة احصائية بين الأسر

$$
\text { من حيث مستوى الدخل الأسري. }
$$

الكلمات المفتاحية: مشكلات نو افق الأيتام، ذوي الظروف الخاصة، الأسر الحاضنة، التوافق النفسي والاجتماعي. 


\section{Compatibility Problems among The Orphans of Special Conditions within Their Foster Families (A study Applied to Foster Families in Medina)}

\section{Abstract}

The study aimed at psychological compatibility, the point of view of the family, the joint family was in the joint family, in addition to identifying the joint family in the family and Medina, in addition to identifying the joint family in the atmosphere, and, finally, the special circumstances from the families' point of view, the study sample is (99) The researcher used the descriptive approach and the type that the researcher adopted in achieving the objectives of the study, the psychological and social compatibility questionnaire prepared by the researcher. The questionnaire consisted of their own set of statements (30). The atmosphere of their oceans, and for a common benefit between their atmosphere, and the point of view of families, the study reached a number of results, the most important of which are: High averages of phrases for the first axis (psychological compatibility), presented in order as follows: The child's feeling of warmth, protection and belongingness The self-confidence is great and high with family members. While the second axis (social compatibility) came its expressions of height, as follows: The child was distinguished by acquiring skills with his peers. This phrase was present in one of the families, one of the families in revenue. There are statistically significant differences between families in terms of the level of family income.

Keywords: Compatibility problems of orphans, People with special circumstances, Foster families, Psychological and social compatibility.

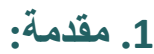

تعتبر حالة التو افق الأسري للأطفال بالأسر العادية في حاجة إلى زيادة من البناء و إثباع الحاجـات البيولوجية و الفسيولوجية التي يحتاجها الطفل حتى لا تتعرض الأسرة إلى مشاكل قد تنهكهم في كثير من الضجر و الضيق و التعب، فهؤلاء هم الأطفال العاديين الذين يعيشون مع الأسرة الأولى، ما بالنا في الطفل اليتيم حينما يتعايش مع أسرة ثانية لم تكن الأسرة هي الو الدة له بل هي مجرد راعية تقوم على توفير احتياجاته وتقوم بمهام الأسرة البديلة أو الكافلة فتكون الصدمة للأسرة و الطفل في حال تذمر

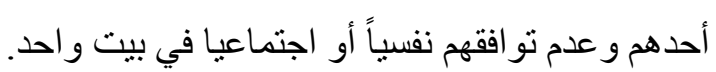
لذلك تعتبر مرحلة الطفولـة من أهم مر احل نمو الإنسـان حيث تكمن أهميتها في كونها ليست مرحلة إعداد للحياة المستقلة فحسب و إنما أيضاً مرحلة النمو الفرد من جميع جو انبه، 
ففي ضوء ما يتلقاه فيها من رعاية وتنشئة اجتماعية وما يكتسبه من خبر ات تحدد معالم شخصيته في المستقبل، ويكسب الطفل في الأسرة مجمو عـة من عـادات التكيف التي تمكنه من أن يتو افق مع معظم الظروف التي يتعرض لها وتعد هذه العادات و السلوكيات المقبولة من المجتمع هو الذي يجعلنا نؤكد القول أن الطفل في السنوات الأولى من حياته يمر بعملية تربويـة لها

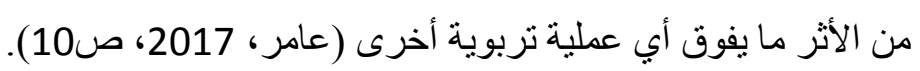
و الحكمة من مخالطة الأيتام ذوي الظروف الخاصـة والتعايش معهم، سد الفر اغ النفسي الذي يتركه فقدان أحد الو الدين أو كلاهما حتى ينشأ اليتيم مع أناس يتعايش معهم بشكل طبيعي ومنو ازن و لا يصبح في عزلة عن عن المجتمع فيفقد و لاءه و انتمـاءه فليس المقصود شموله بالعطف و الثفقة و إنما الإصلاح لله وتهيئته ليصبح عضو ا فاعلا في المجتمع و إن فهم حاجـات الطفل اليتيم ومن في حكمه وطرق إثباعها يقلص من تعرضه للمشاكل (السدحان، 2009، ص124).

وتؤكد العديد من الدراسات على أن التوافق أمر نسبي يختلف باختلاف المكان والزمان فقد يكون الفرد متو افقاً في مجتمع ولا يكون منو افقاً في مجتمع آخر وتضيف الدراسات أن التوافق يدل على الصحة النفسية إذا كانت أهداف الفرد تتفق مـع معايير وقيم المجتمع و إثباعها بسلوك مقبول ويدل على ضعف الصحة النفسية إذا لم يبارك المجتمع أهدافه أو كانت سلوكياته تثير سخط الناس ويعني تو افق الفرد مع نفسه رضاه عنها و عن ماضيها وحاضـر ها ومستقبلها وتقبله لقدر اتها وصفاتها وحاجاتها

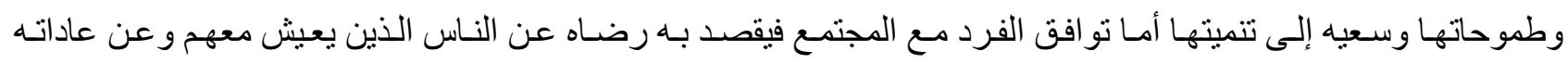
وتقاليدهم وشـعوره بالتقبل و الحب و التعاون معهم ور غبته في الالتز ام بقو اعد السلوك السـائدة في مجتمعه ومن المعلوم أن

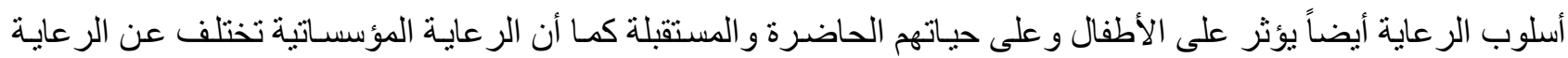

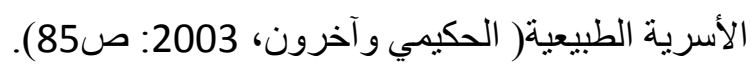
كما تعد الأسرة من أهم المؤسسـات الإجتماعيـة التي لها تأثنير قوي وواضتح على الطفل في تشكيل شخصيته وتكوينها عن طريق عملية التنشئة الاجتماعية التي تعمل على تحويل الطفل من مجرد كائن بيولوجي إلى فرد بمتلك عادات وتقاليد وتر اث

$$
\text { وسلوك الجماعة التي ينتمي إليها. }
$$

وفي هذا الصدد يوضح عالم النفس الإجتماعي الآلماني " رينية كوبنج Ren Koming" أن العامل الحاسم في وجود الإنسـان و استمر اره هو الميلاد وليس الثاني وليس الميلاد الأول البايولوجي، ويقصد بالميلاد الثاني هو امتلك الفرد شخصية اجتماعية ثقافية تتنمي إلى مجتمع وتدين بثقافة ذلك المجتمع وبطبيعـة الحسال فإن صـاحبة الفصل في تحقيق المبلاد الثاني هي الأسرة

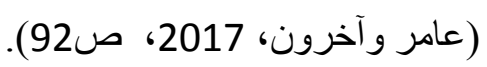

ومن هنا يتبين لنا الدور الخطير الذي تؤديه الأسرة في حياة الطفل ونستطيع أن نلمس كيف أن الكثير من مظـاهر التو افق أو عدم التو افق التي تظهر في سلوك الأفر اد وتحقيق نجاحهم أو فثلهم في الحياة يمكن إرجاعها إلى نوع العلاقات الإنسانية التي سـادت بين أفر اد الطفل في مختلف مر احل حياتـه الأولى و إلى أسـاليب المعاملـة التي واجهها في الحياة (عامر وآخرون،

لذلك بسعى الباحث في هذه الدر اسة الى التعرف على أهم مشاكل التو افق سو اء كانت نفسية أو إجتماعية التي تو اجـه الأطفال

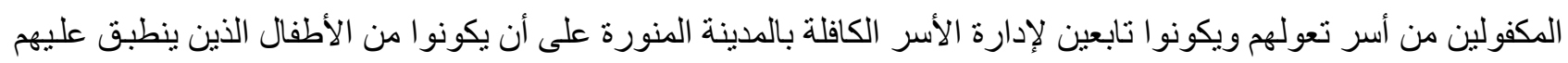


الهجلد الثالث - الإصدار الثامن والعشرون تأريخ الإصدار: 20 فبراير 2022 م

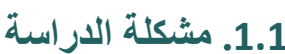

تبرز المشكلة الو اقعية التي تو اجه هذه الفئة وتشكل خطورة تهدد الكيان النفسي لها هي المشكلات التي تتعلق بالهوية والاندماج الاجتماعي و الو عي بالذات و الاستبصار بحقيقتها ذلك أن معظم من يتعامل مع هذه الفئة يتعاملون معهم بحذر فلا ييصرونهم بحقيقته و لا يو اجهونهم بها و إنما يتحاثنون ذلك ويخفقون فيه لما يشكل لهم هذا الأمر من حرج في جانبين الطفل من النظر إليه بأنه مجهول الو الدين و هو ما اتضح أثنـاء التعامل مـع هذه الفئة لمحاولة فهم طبيعتها وحاجاتها ومعرفة أكثر المشكلات انتشار فيها حيث ظهرت بعض التصور ات حول الجوانب المهمة التي هي بحاجة إلى تطوير وتغيير لضمان تحسين مستوى الو عي لهم و إن و عي الطفل بذاته عملية تعينه على تحقيق التو افق الاجتماعي و هذه التفاعلات تحتاج منه أن يكون متمكنا من مهار ات أساسية يعرفها باسيشن وفينيتا (Bastian and veneta,2005,p73) بأنها مجمو عة أعمال و أنشطة يقوم بها الفرد في الحياة اليومية وتتضدن تفاعله مع أشبياء ومعدات و أشخاص ومؤسسـات وتتطلب هذه التفاعلات تمكن الفرد من التعامل معها بدقة ومهارة( عبدالعاطي، 2005م، ص42). حيـث تعد الأسـرة المركز الرئيسـي التي تسـهم في تكوين شخصية أبنائهـا ولهـا الـدور الأكبر في التأثير في مجـالات

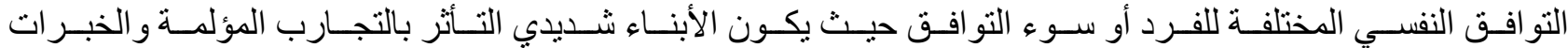

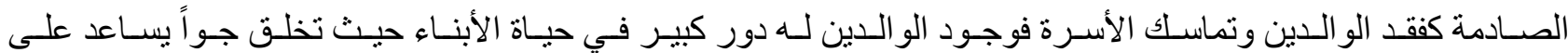

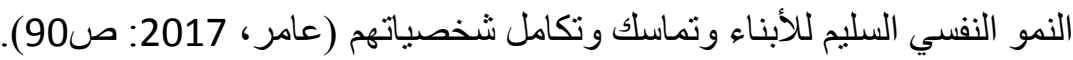
يعاني فيها الأيتام من المشكلات السلوكية أو الإجنماعيـة والنفسية بسبب إفتقادهم لوجود أحد الأبوين أو كليهمـا ممـا يؤدي لاضطر اب تو افقهم مع المجتمع ويؤثراً سلباً على اكتسـاب الأبناء للقيم الاجتماعية كالتعاون مع الآخرين و الحوار ويكونوا كذلك أقل سعادة ونو افقاً واستمتاعاً بحياتهم مقارنة بالذين يعيشون مع أسر هم(Paul,\&Bruce,1999,p.26).

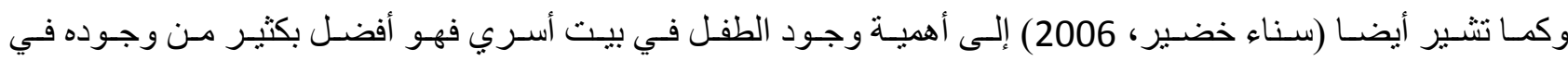

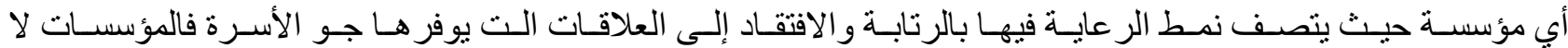
بمكنها تزويد الطفل بالإشباع العاطفي وتنمية الحس المناسب وتعلم أنواع السلوك الاجتماعي أو الإنفعالي.

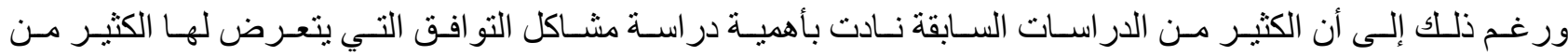

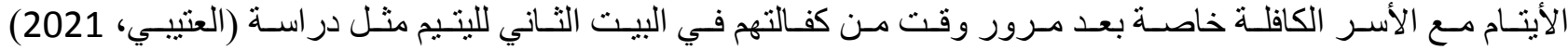

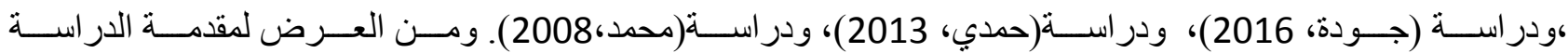

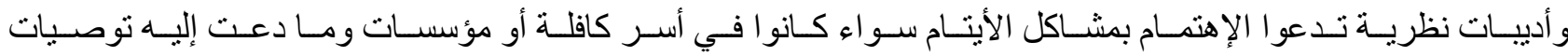
بعضــــــن الدر اســات السـابقة مثــل در اسـة( العتيبـي، 2021) ،ودر اســة (جـودة، 2016)، ودر اســة(حمدي، 2013)،

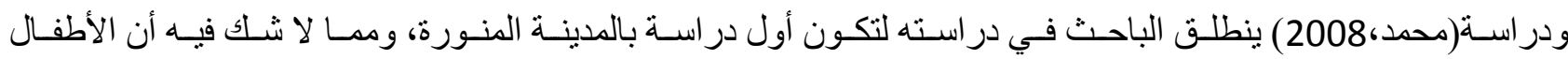

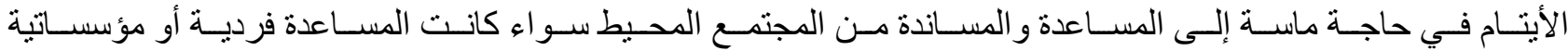

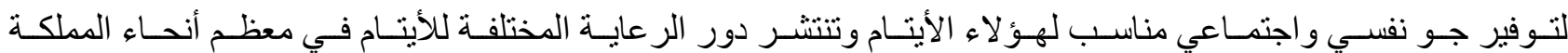

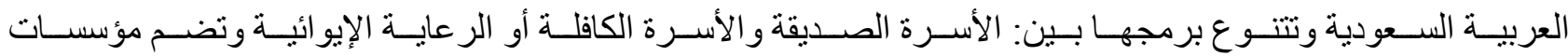
خاصة بالبنين و أخرى بالبنات، 
لـذلك تتـاول الباحث مشـكلة الدر اسـة حـول المشـكلات التو افقيـة التـي تواجـه الأيتـام مـع الأسـر الحاضــة وخاصـة الأسـر

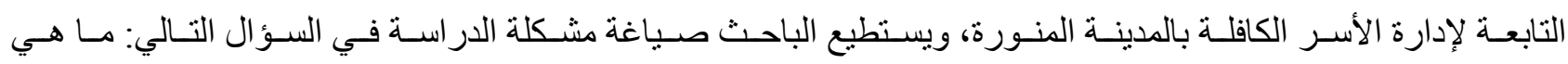
مشكلات التو افق للأيتام ذوي الحاجات الخاصة مع الأسر الحاضنة بإدارة الأسر الكافلة بالمدينة المنورة؛

2.1 2.1 أهداف الدراسة 1- التعرف على قياس التو افق النفسي والاجنماعي لدى الأيتـام ذوي الظروف الخاصـة من وجهة نظر الأسر الكافلـة

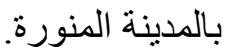

2- التعرف على الاختلاف في التو افق النفسي والاجتماعي للأيتام ذوي الظروف الخاصة من وجهة نظر الأسر الكافلة. 3- الكثف عن درجة الاختلاف في التو افق النفسي والاجتماعي لدى الأيتام ذوي الظروف الخاصة من وجهة نظر الأسر الكافلة من حيث المستوى الاقتصادي.

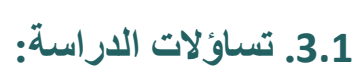

1- ما هو مستوى التو افق النفسي و الاجتماعي لدى الأيتام ذوي الظروف الخاصة من وجهة نظر الأسر الكافلـة بالمدينة

$$
\text { المنورة: }
$$

2- هل يختلف مستوى التو افق النفسي والاجتماعي للأيتام ذوي الظروف الخاصة من وجهة نظر الأسر الكافلة؟ 3- هل توجد فروق ذات دلالة إحصائية في مستوى التو افق النفسي و الاجتماعي لدى الأيتام ذوي الظروف الخاصـة من

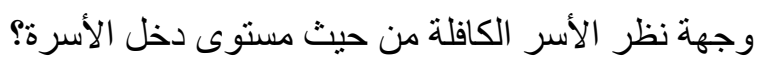

1- الاهتمام بفئة مهمة في مجتمعاتنا الإسلامية على وجه الخصوص فهي من الفئات المحرومة والتي يمكن أن تتأثر

وتؤثر سلباً على المجتمعات التي تعيش فيها ومساندة المجتمع لهذه الفئة التي يجنبها الكثير من السلبيات.

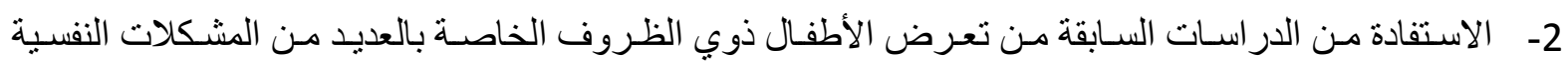

$$
\text { و الاجتماعية بالإضافة إلى نقص في إثباع العديد من الاحتياجات. }
$$

3- قلة الدر اسات و البحوث التي تتاولت الأطفال ذوي الظروف الخاصة واحتياجاتهم ومشكلاتهم من منظور الخدمة

$$
\text { الاجتماعية خاصة في المملكة العربية السعودية. }
$$

ثانياً: الأهمية العملية: - م

1- خفض الكثير من المشكلات التو افقية النفسية والاجتماعية في تحقيق السعادة و السو اء لهؤ لاء الأطفال الأيتام.

2- وضع رؤية و اضحة حول طريقة تفادي المشكلات النفسية والاجتماعية للأطفال ذوي الظروف الخاصة. 3- وضع رؤيـة واضـحة حول طرق التعامل الجيد مـع الأطفال ذوي الظروف الخاصـة خاصـة بـالإدار ات الكافلة

$$
\text { لهؤ لاء الأطفال. }
$$


5.1 5 مفاهيم الار استة

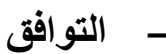

تعرف لغوياً: الكلمة: التو افق .الجذر: وفق. الوزن: التَََّاعُل. التو افق نو افقو ا بالنبل: أي أوفق بعضهم بها لبعض.

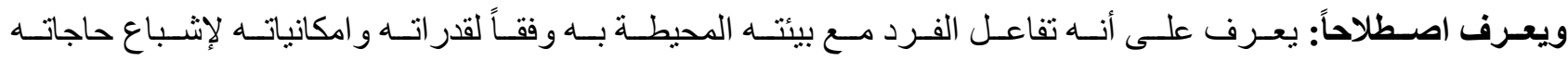

ور غباته وفقاً للظروف الخارجية التي تمليها عليه تلك البيئة (عبد الحليم، 2015، ص57).

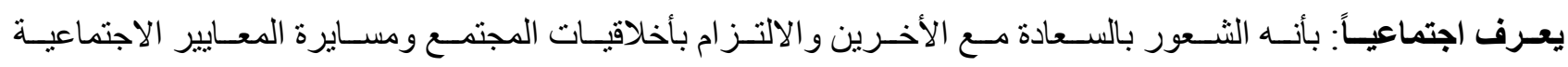

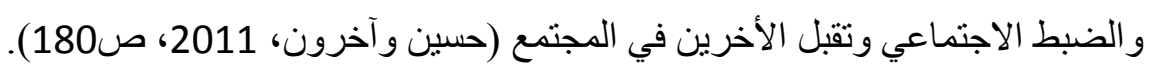

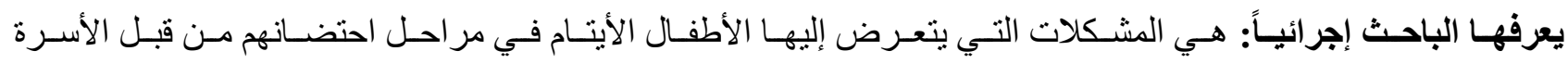

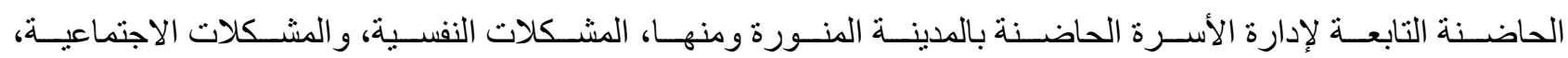

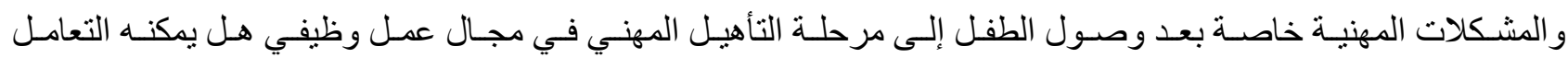

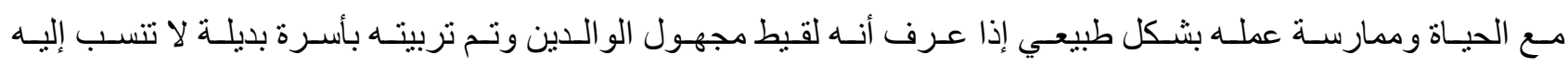

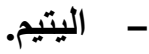

يشير مفهوم اليتيم لغوياً: إلى الصبي الذي فقد أباه قبل البلوغ الطفل الذي يفقد والديـة الأم والأب معاً ممـا أدى ذلك إلى عدم وجود بدائل ثابتة له: الأمر الذي بفقد الطفل شك الحياة الأسرية الطبيعية ممـا أدى ذلك إلى إيداعه بإحدى المؤسسـات (عامر،

2017: ص12)

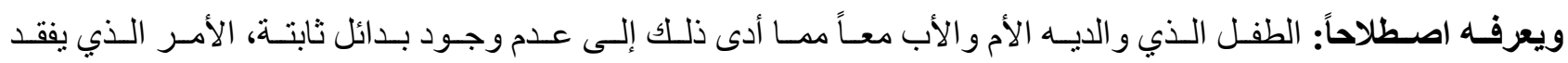
الطفل شكل الحياة الأسرية الطبيعية مما أدى إلى إيداعه بإحدى المؤسسات (عامر، 2017: صداند).

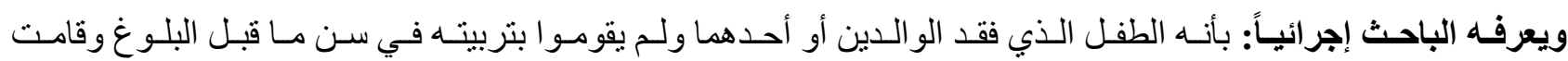
أحد الأسر الكافلة التابعة لإدارة الأسر الكافلة بر عايته وتوفير احتياجاته الأساسية.

\section{- - ماي الظروف الخاصة:}

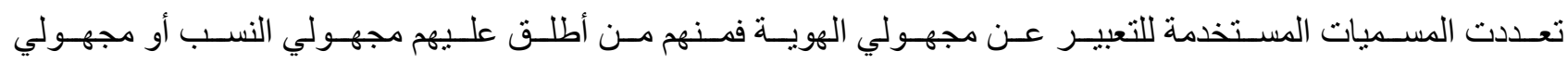

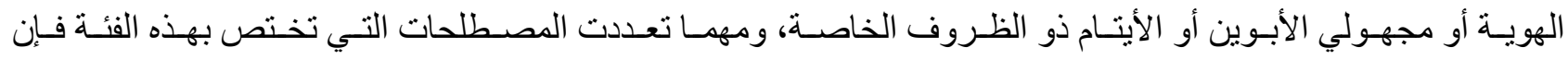

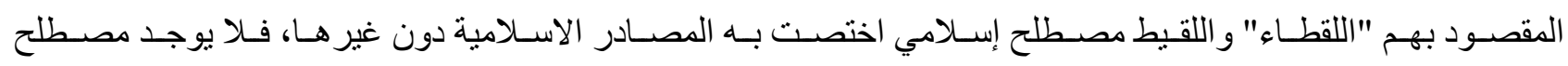

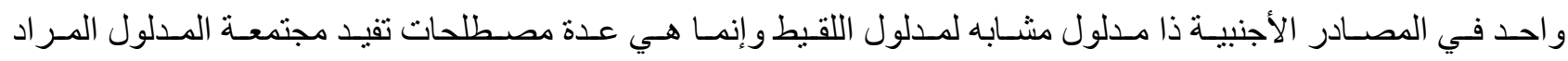
باللقيط (العساف، 2005، صـ4 (41).

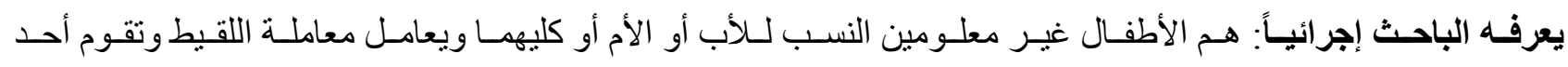
المؤسسات أو الأسر الكافلة بتربيته لسن البلوغ. 


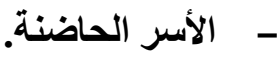

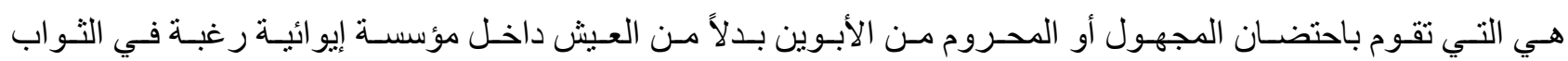

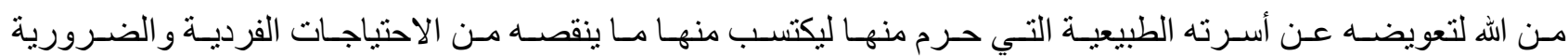

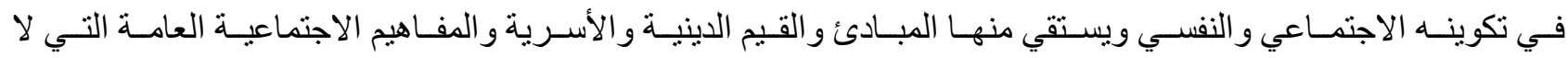

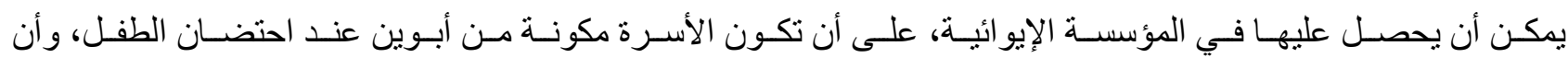
يتوفر لايهم المكان المناسب لتنشئة الطفل غير الثرعي تنشئة صحية سليمة (نصار ، 2006، ص9).

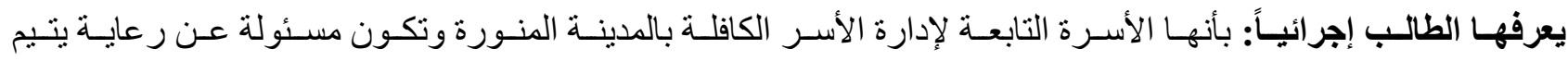
ويطبق عليها لو ائح الإدارة في تربية اليتيم.

2. الإطار النظري والدراسات السابقة.

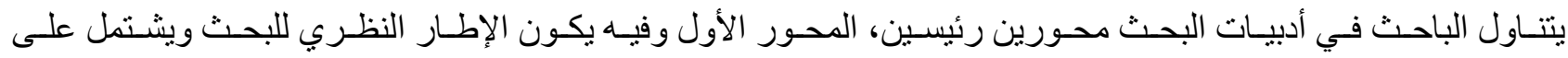

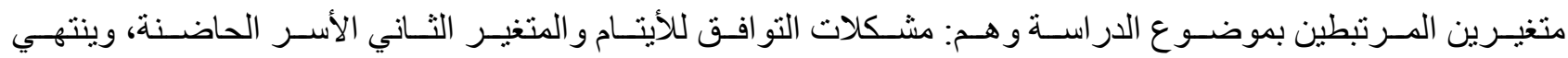
الفصل بالمحور الثاني ويشمل الدر اسات المرتبطة بالموضوع ثم تعقيب عام على الدر اسات السابقة. 1.2 - م. الإطار النظري: مشكلات التوافق: المعنى اللغوي للتوافق: عرفه (ابن منظور، 2002، ص252) وفق الوفاق: المو افقة والتو افق والاتفاق و التظاهر وفق الثـئ ما لاعمة وقد وفقهـه موافقة ووفاقا واتفق معه وتو افق وتقول هذا وفق هذا ووفاقه وفيقه وفوقه وسيئه و عدله وو افقت فلانا على أمر كذا أي اتفقنا عليه معاً. المعنى الاصطلاحي للتو افق: عرف (عبد المجيد، 2002، ص316) التو افق بأنه ثــرة التكيف وهو ليس فقط أن يتغلب الفرد على العقبات أو العو ائق الر اجعة إلى قدرته سو اء بالعجز أو بالزيادة في هذه القدرة فإنه يو اجه عقبات أخرى من نوع برجع أساساً إلى تغيرات ظروف الحياة ومو اقف الفرد ويتعين عليه تخطى هذه العوائق أيضاً. مستويات التوافق: ذكرت (ايناس أحمد، 2007، صويات 19) أن هناك ثناثة مستويات للتو افق هي:

$$
\text { 2. }
$$

أولاً: التو افق على المستوى البيولوجي. 
يشترك كل من لور انس وشوبين في أن الكائنات الحية تميل إلى أن تغير من أوجه نشاطها في استجابتها للظروف المتغيرة في بيئتها ذلك أن تغير الظروف ينبغي أن يقابله تغيير وتعديل في السلوك بمعنى أنه ينبغي على الكائن الحي أن يجد طرقيا جديدة لإثباع رغباته و إلا كان الموت حليفه أي أن التوافق هنا إنما هو عملية تتسم بالمرونة والتو افق المستمر مع الظروف المتغيرة. ثانباً: التو افق على المستوى الاجتماعي. يرى شافر إن الحياة إنما هي سلسلة من عمليات التو افق التي يعدل فيها الفرد سلوكه في سبيل الاستجابة للموقف المركب الذي ينتج عنه حاجاته وقدرته على إنثباع هذه الحاجات ولكي يكون الإنسان سويا ينبغي أن يكون تو افقه مرنا وينبغي أن تكون لديه القدرة على استجابات منو عة تلاءم المو اقف وتنجح في تحقيق دو افعه. ثالثاً: التو افق على المستوى السيكولوجي. تذكر (ايناس أحمد، 2018، ص40) إن الكائنات الحيـة تميل إلى أن تحتفظ بحالـة من الاتزان الداخلي إلا أن الصر اع صفة ملازمة لكل سلوك وترى أن التو افق السوي بأنه اعندال في الإثباع إثباع عام للثخص عامة لا إثباع لدافع واحد شديد على حساب دو افع أخرى و الثخص المتو افق نو افقاً ضعيفا هو الثخص غير الواقعي وغير المشبع بل والثخص المحيط الذي يميل

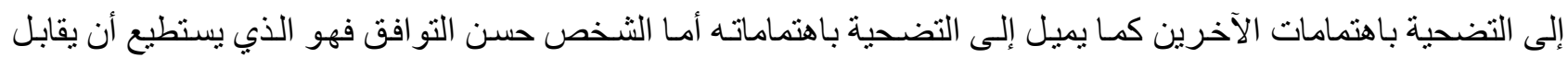
العقبات و الصر اعات بطريقة بناءة تحقق له إثباع حاجاته و لا تعوق قدرته على الإنتاج.(محمد،2018، ص14). معوقات التوافق: الثخص لديه احتياجات ضرورية و إذا لم بشبعها يؤدي به إلى عدم الوصول إلى الأهداف المطلوبة وبالتالي تعتبر من معوقات

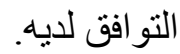
ويرى (الدسوقي، 1985، 34) أن المعوقات لدى الثخص تتمثل في عدم قدرته على القيام بفاعلية التي ينتظر ها الآخرون منـه وتتمل معوقات جسمية و عقلية واجتماعية وهي:

1. معوقات جسمية: في الأعضاء وضعف البنية وشكل وحجم الجسم عدم التوازن في الغدد نقص الاستعداد الرياضي نقص أجهزة الحس(كالسمع) نقص أجهزة الحركة (كصلابة المفاصل) عدم جاذبية الثنكل أو المظهر. 2. معوقات عقلية: انخفاض الذكاء لدرجـة عدم مسايرة في التعليم أو القائم بعمل مهني أو العكس بقدرة مبالغـة فيها كإجبـار الآبـاء للأبنـاء الحصـول على معدل عـال لمـا لدى الفرد باستعداد مـن نقص طبيعي في قدرة معينـة كعدم الاستعداد للرياضيات. 3. معوقـات اجتماعيـة: نقص الصداقة وعدم قدرتـه على كسب الأصدقاء عدم القدرة على صيانة الأنـا في مو اجهة السخرية أو التهم مع الكبار و الأعلى درجة.

المشكلات للأطفال الأيتام: يـذكر (الخو الـدة، 2020، ص18). مشـكلات الأطفــال المحـرومين مـن الرعايـة الأسـرية يعـانون مـن مشـكلات عديـدة

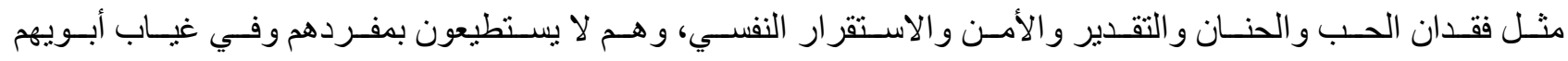

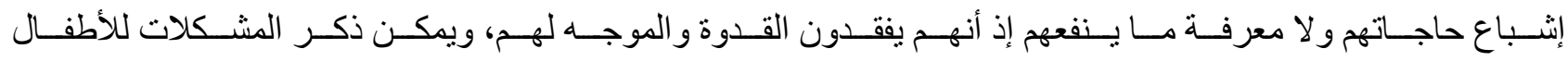
المحرومين من الأسر أو الو الدين في التالي: 


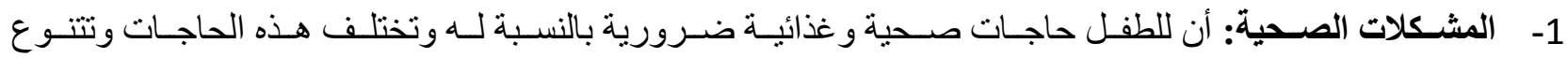

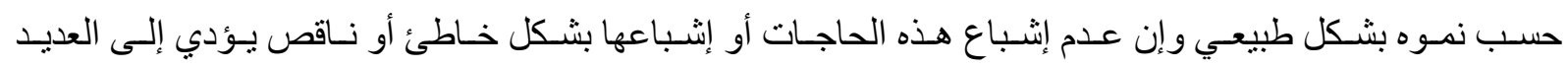

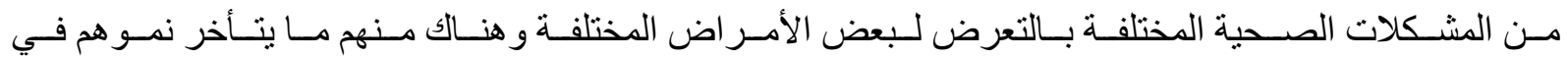
جو انب معينة من الجسم وقد يرجع ذلك إلى أسباب ور اثية أو متعلقة نقص في الرعاية و العناية بالتغذية.

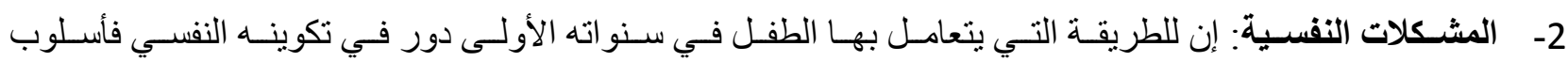

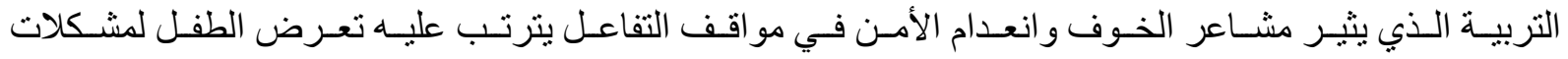

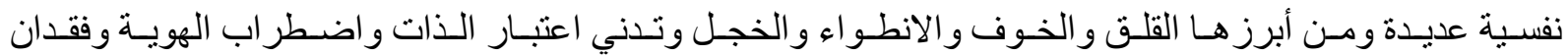

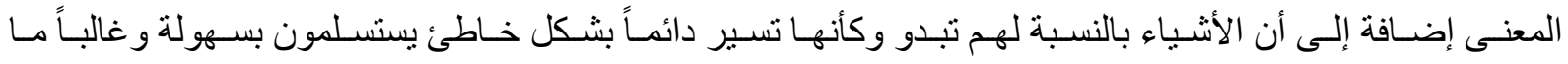
يثــرون بـالخوف ويصـفون أنفسـهم بصـفات منـل سـيء و عـاجز ويتعـاملون مـع مو اقـف الإحبـاط و الغضــب بطريقة غير مناسبة.

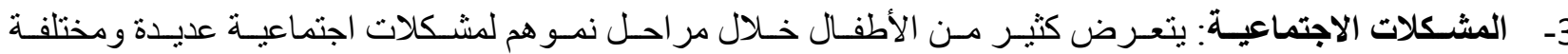

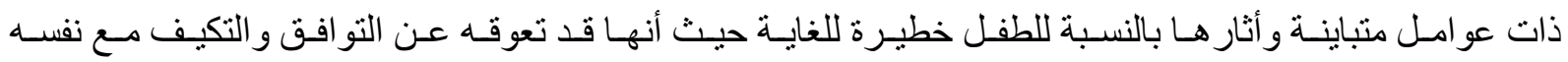
بصفة عامة وأبرز ها العزلة الاجتماعية و عدم المشاركة وضعف العلاقات الاجتماعية.

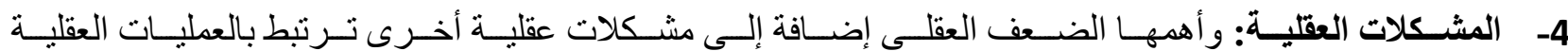
المعروفة كالتخيل و التركيز و التر ابطو التفكير. أساليب التوافق: يعتبر التوفق هـ الأسـاس في الصـحة النفسية بـل إن بعض التعريفـات قد عرفت الصـحة النفسية على أنهـا قدرة الفرد على التو افـق و التكيـف إن الفـرد ككـائن اجتمـاعي عليـه أن يشـبع حاجاتـه ويحـل مشـكلاته بالأسـلوب الـذي يحفـ نـوتره

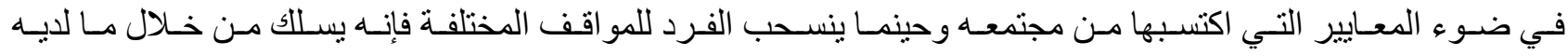

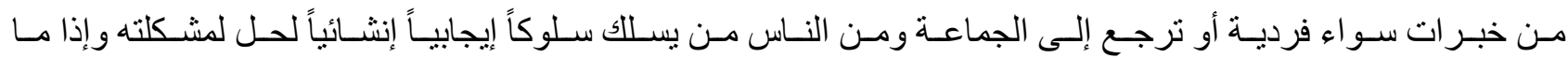

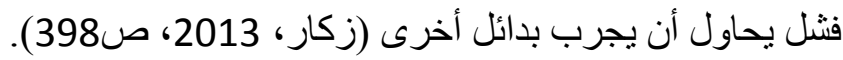
ويذكر (أبو حطب، 1985، 170). ان التوافق ينقسم الى قسمين:

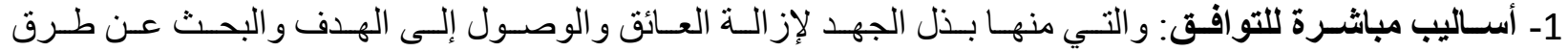
متعددة للوصول إلى الهدف و استبدال الهدف بغيره واستخدام أسلوب حل المشكلة.

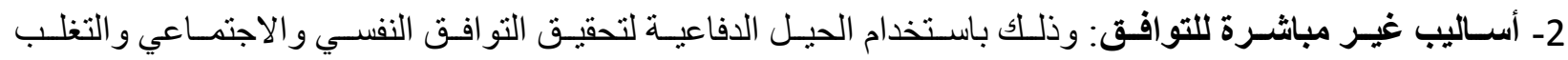

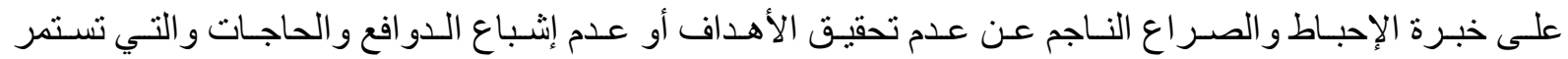
لفترة طويلــة بسـبب عجزه عـن التغلب عليهـا بـالطرق المباشـرة ومـن هـذه الأسـاليب الكبـ، الاسـقاط، التقمص، التوحد، و غير ها من أساليب الحيل الدفاعية. 


\section{نظريات التوافق:}

النظرية التحليلية: أهتم كثير من علماء بدر اسة الثخصية إلى إعطاء التو افق موقفاً واضحاً في در اسـاتهم العلميـة الدقيقة بحيث اعتبر التو افق و الثخصية موضوعين متلازمين ومن العسير التحدث عن أحدها دن الآخر فما من شخصية سليمة إلا وتتسم بالصحة النفسية السليمة و السلوك التو افقي (الخالدي، 2001، صوب9).

- ـ فرويد: اعتقد فرويد أن عملية التو افق الثخصي غالباً مـا تكون لا شـعورية أي أن الأفر اد لا تعني الأسـاليب الحقيقية لكثير من سلوكياتهم ويرى فرويد أن العصاب و الذهان ما هي إلا عبارة على شكل من أثكال سوء التوافق ويقرر أن السمات الأساسية للشخصية المتو افقة و المتمتعة بالصحة النفسية تتمثل في ثلاثة مسميات هي قوة الأنا.

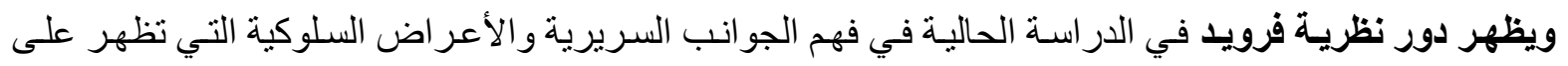
الأطفال للتعرف على أهم المشكلات التي يو اجهها الأطفال وخاصة إن كانت تللك المشكلات ترتبط بالجو انب النفسية، وجاء الباحث للتطرق لنظريـة فرويد في فهم الخصـائص النفسية للطفل وخاصـة في مر احل الطفولـة ودور الكافل للطفل بعد كفالته لتلاشي أهم السلبيات التي يتعرض لهاء الطفل. - يونج: اعتقد يونج أن مفتاح التو افق و الصحة النفسية يمكن في استمر ار النمو الثخصي دون توقف أو تعطل كمـا أكد على أهمية اكتشاف الذات الحقيقية وأهمية التوازن في الثخصية السوية المتو افقة.

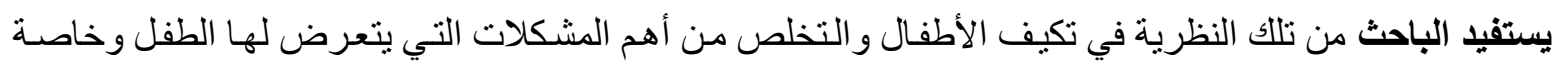
المشكلات الاجتماعية التي يتعرض لها أثنـاء فترة تربية الطفل من الكافل وحتى يمكن اخر اج طفل سوي مو ائم لتغير ات البيئة. - أدلر: اعتقد أن الطبيعة الإنسانية تعد أساساً أنانية وخلال عمليات التربية فإن بعض الأفر اد ينمون ولايهم اهتمـام قوي ينتج عن رؤية الأخرين مستجابين لرغباتهم ومسيطرين على الدافع الأساسي للمناقشة دون مبرر ضد الأخرين طالباً

$$
\text { للسلطة أو السيطرة (محمد، 2004، 24). }
$$

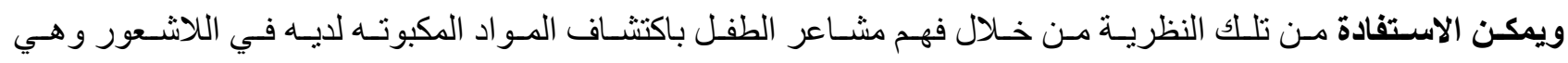

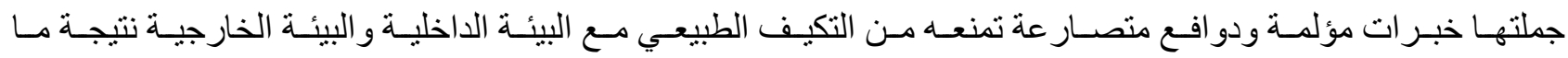
تعرض له الطفل من ذكريات غير سارة في حياته الأولى وتمنعه من التكيف الطبيعي.

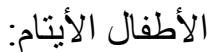

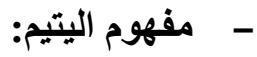 \\ مفهوم اليتيم لغة:}

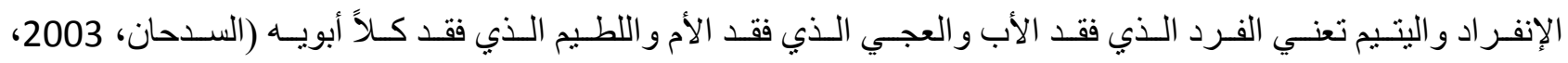

ومفهومه اصطلاحاً:

هو الطفل الذي فقد كلا الآباء أو و الديهم فقط (Tania Boker \& Kate carroll,2003,p2) 


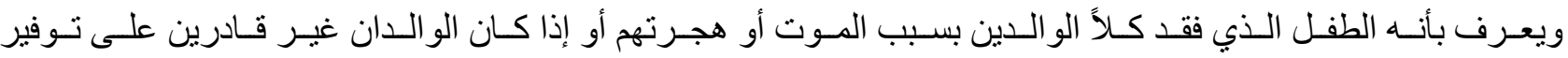
الرعاية أو غير راغبين ويتم تصنيف الطفل يتيما ضمن طيفات الضعفاء (tsheko,2004.p2، Skinner). - - أنواع اليتيم: -

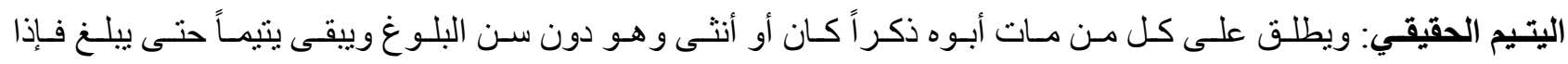
بلغ زال عنه اليتيه.

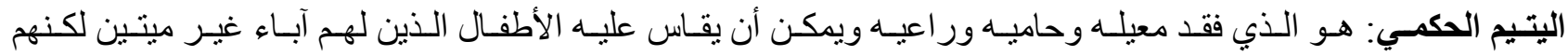
في حكم الأمـوات ويمكن اعتبـار أو لادهـ في حكم الأيتـام وفي المجتمع نمـاذج كثيـرة مـن هــه الأصـناف مـن الناحيـة

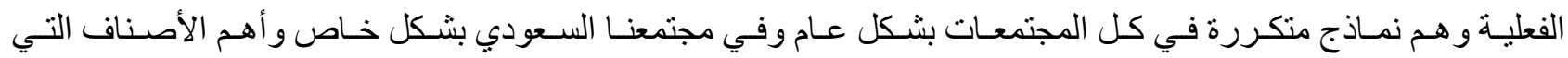

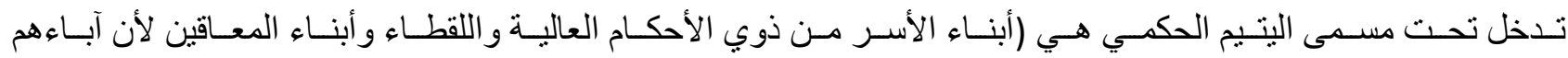

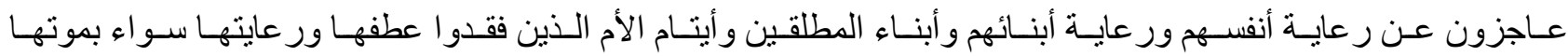

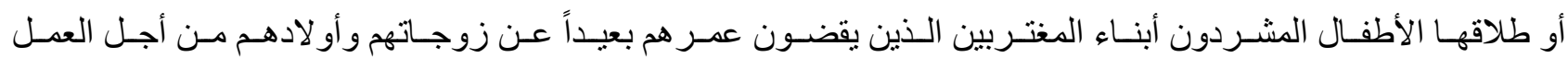
أبناء المفقودين الذين انقطعت أخبار هم فلا يعرف موتهم من حياتهم (كلاب، 2014، 70).

-

1

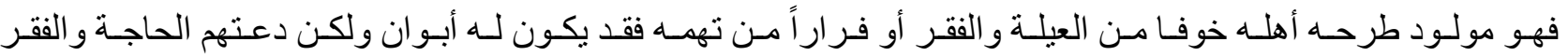

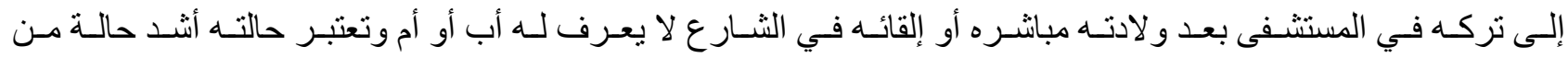

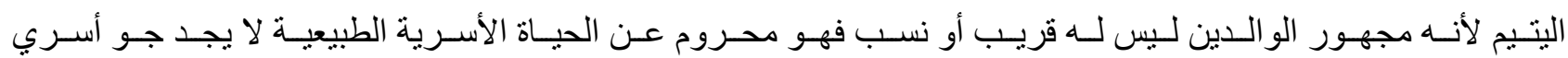

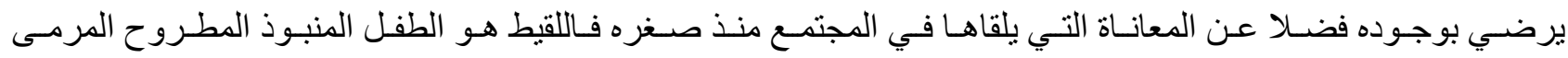
به مجهول الأبوين و النسب (السدحان، 2003، صبوس 11).

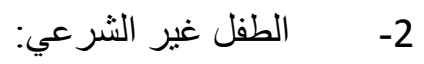

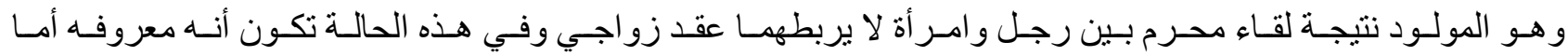
و الده غير معروف (أبو الحسن، 2015، 142).

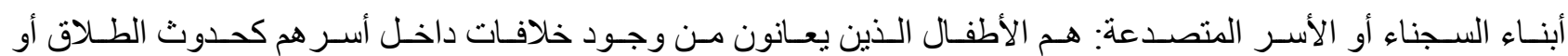

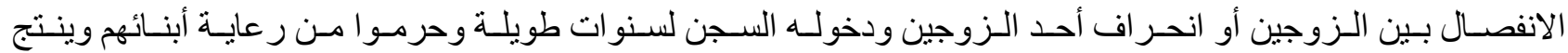
عن ذلك تشرد هؤلاء الأطفال (أبو الحسن، 2015، صنرون 142). تعـد ظــاهرة الأطفـال الأيتـام مـن الظـو اهر الإجتماعيـة التـي ظهـرت و انتشـرت فـي المجتمعـات العربيـة بشـكل ملحـوظ

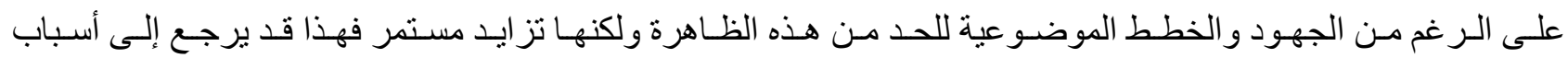

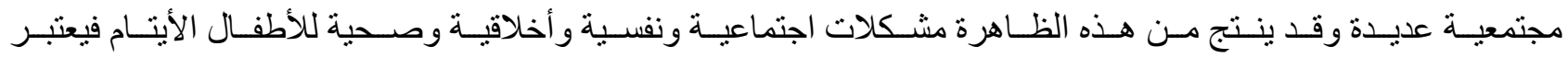

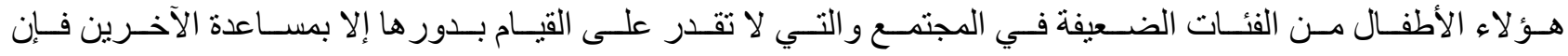




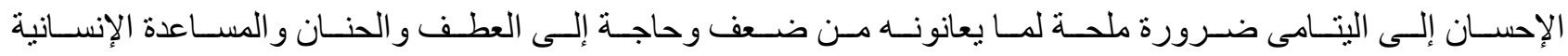

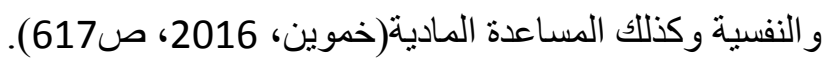

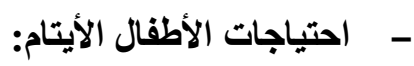

تتعـد احتياجـات الأطفـال الأيتـام فهـي لا تختلـف عـن الاحتياجـات لـدى الأطفـال العـاديين فـي أسـر هم إلا أن الاهتمـام

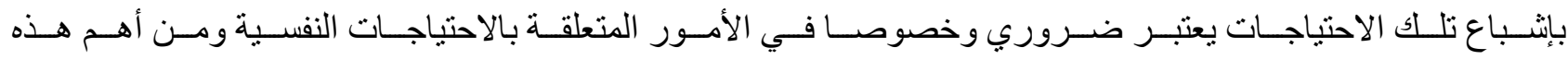

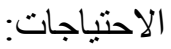

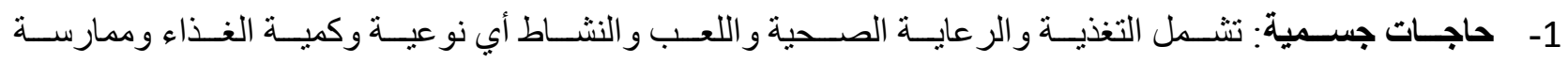

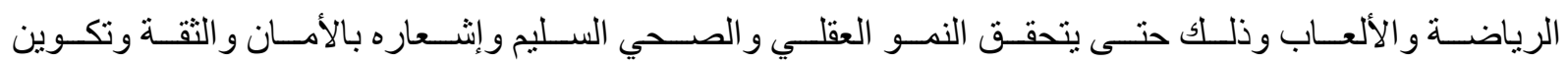
الثخصية المتكاملة وإحداث التفاعلات الاجتماعية بالمجتمع (عامر، 2000، 429).

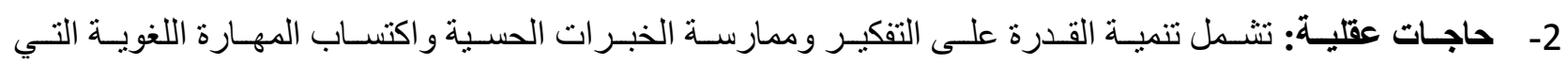
تغذى قدرة الطفل على التفكير و البحث و الاستطلاع و المعرفة (عامر، 2000، 429).

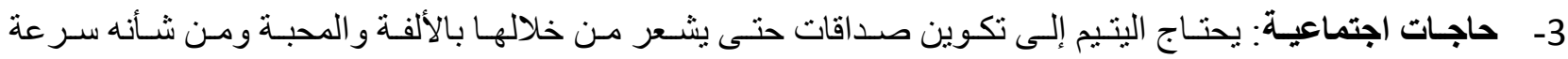

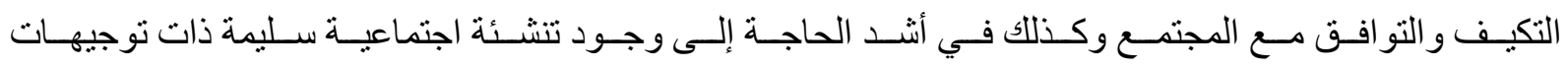

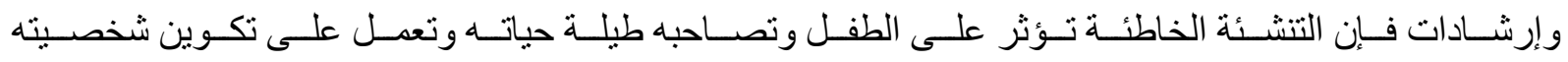

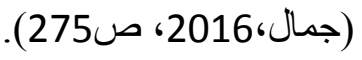

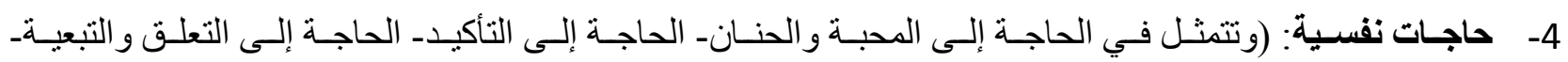
الحاجة إلى المواساة).(عبدالرحمن، 2002، 63).

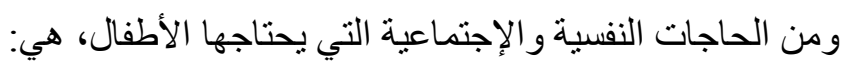

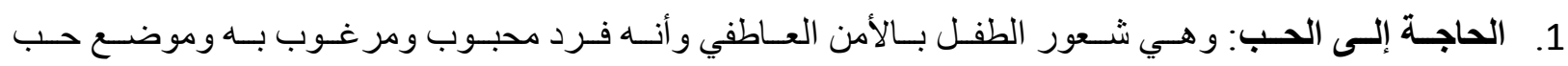
واحتر ام من الآخرين. 2. الحاجة إلى العطف و الرحمة والتقدير والاحترام: حاجة الطفل إلى العطف والإحتر ام من الآخرين.

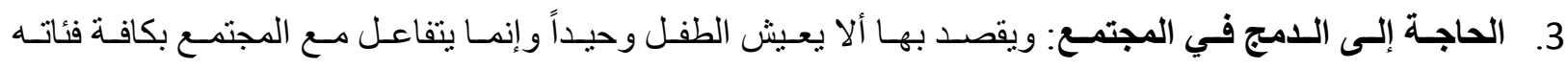
مما يجعله يشعر بالثقة بالنفس.

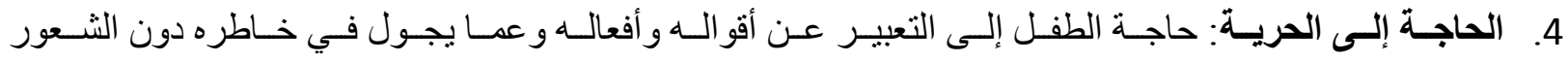

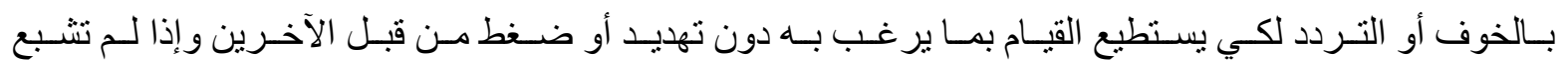

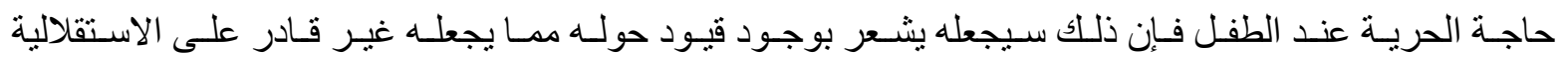

$$
\text { وتحمل المسؤولية (القضاة، 2016). }
$$

ويـرى العـاملون فـي العـلاج النفسـي إن مصـطلح يتهيم يطلـق على كـل مـن فقــ الثـعور بالهويـة الأسـرية و الذاتيـة وعـدم

$$
\text { التقبل الذاتي الداخلي(المشوح،2006). }
$$




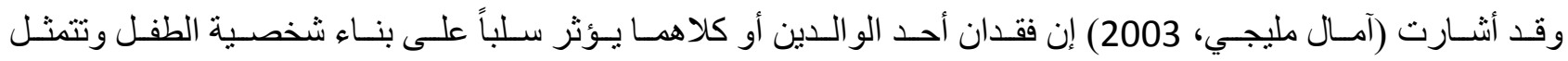
الآثار السلبية بما يلي:

$$
\text { 2- الانطفاض المستوى التحصيل الأكاديمي لاءى الأطفال. }
$$

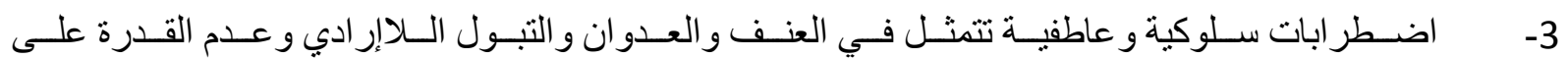

$$
\text { التعامل مع الآخرين. }
$$

$$
\begin{aligned}
& \text { 4- عدم القدرة على التكيف مع المجتمع والبيئة المحيطة. } \\
& \text { 5- - فقدان الثهية و انخفاض مستوى النمو الجسدي. } \\
& \text { 6- المف المهار ات اللغوية السليمة التي تعتمد على تأكيد الذات. }
\end{aligned}
$$

ويشير رونر وتايلور (Rutter and Taylor,2003) الى إن فئة الأيتام المحرومين من الرعايـة والبيئة الأسرية يعانون من

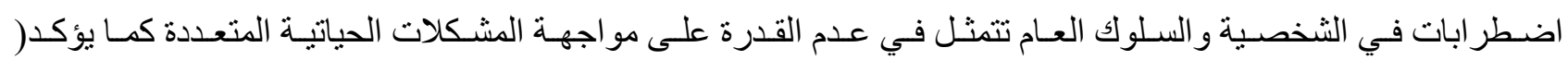
(Carr,2006 أن بناء شخصية الفرد وتحسين مستوى فاعلية الذات لديه يرتكز على السنوات الأولى من عمره ويعتمد على وجود أسرة سوية وأن حدوث أي خلل في العلاقة بين الطفل وأسرته يؤثر على تكامل شخصيته و التو افق عنده.

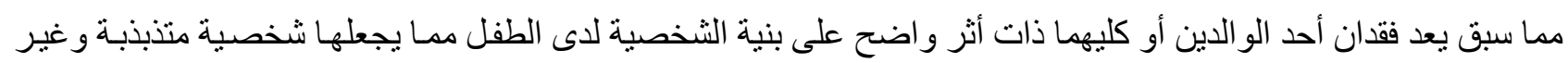
متزنة لديها القابلية لوجود العديد من الاضطر ابات النفسية و السلوكية مقارنة بالأطفال العاديين وبـالر غم ممـا تقدمه المؤسسـات

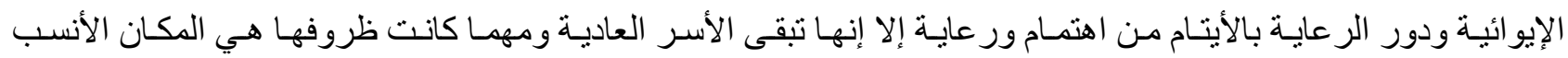

والأفضل لتنشئة الفرد تتشئة سليمة.

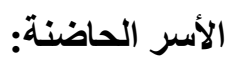

\section{- - تعريف الأسرة الحاضنة:}

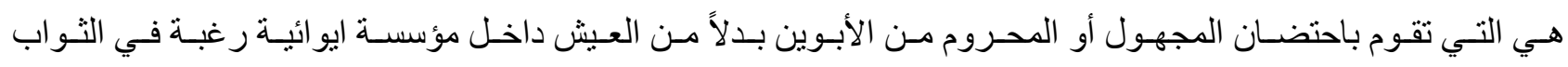

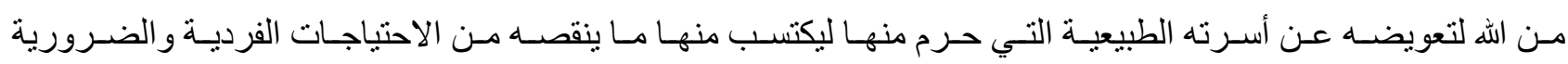

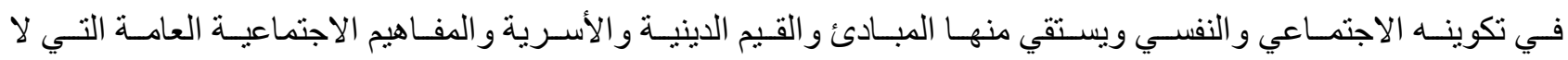

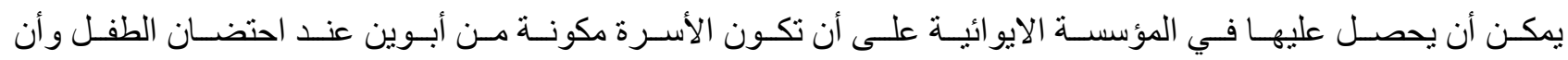
يتوفر لديهم المكان المناسب لتنشئة الطفل غير الثرعي صحية سليمة (الثامي، 2014).

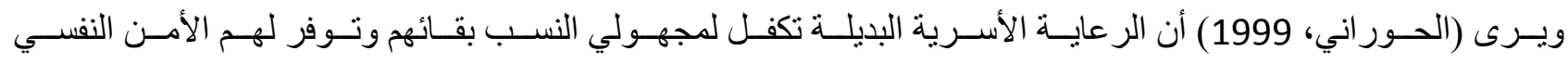
و الجســي و الإجتمـاعي وقـد لجـأ المجتمـع إلـى إتاحـة فـرص مناسـبة لمثنل هـؤل لاء الأطفـال حيـث سـيجدون مـن خلالهـا

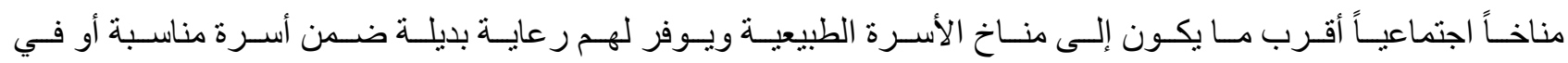
مؤسسة اجتماعية تم إعدادها لمثل هذا الغرض (الثامي، 2014). 
ويعـرف الأسـرة البديلـة فـي قـوانين الأسـرة ور عايـة الطفولـة يتمثنل فـي الأسـرة الحاضـنـة التـي تقـوم باحتضــان الطفـل

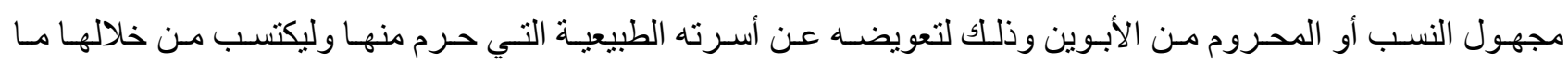

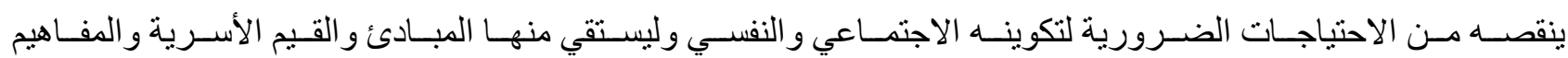
العامة للمجتمع حتى تصبح شخصية مستقرة وصالحة (الأشقر، 2009، 506).

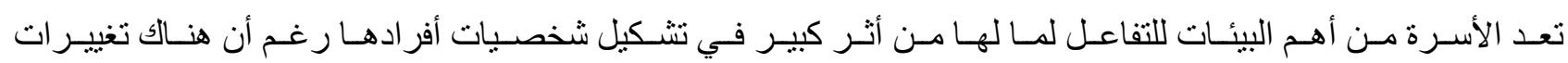

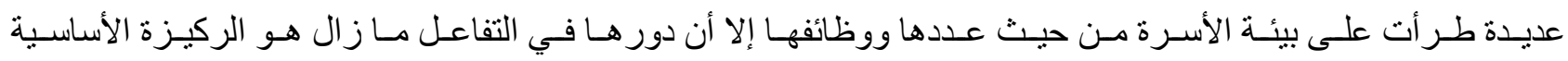

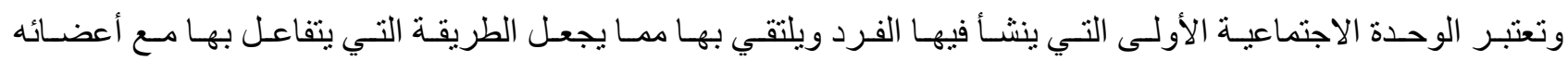

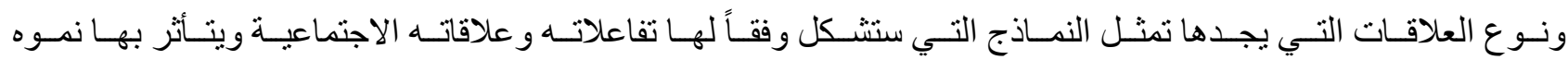
الانفعالي كما أن الأسرة أساسية في تشكيل طبيعة الفرد (عثمان،2005).

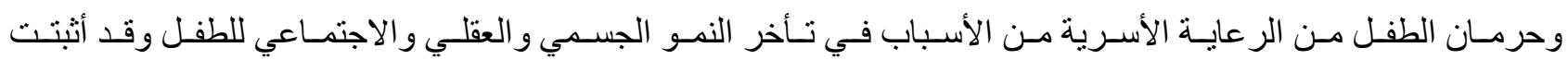

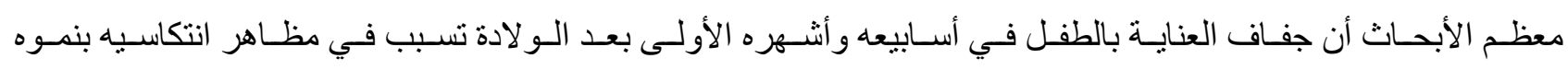

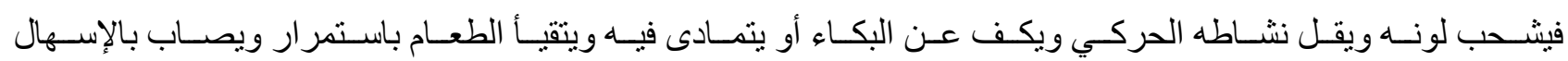

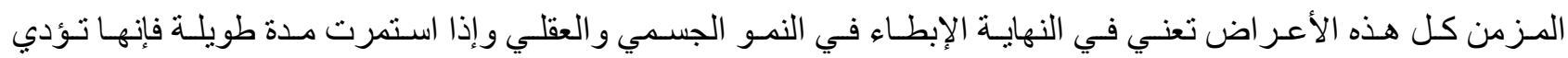

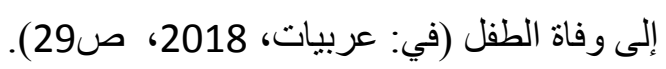

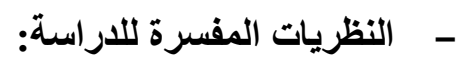

نظرية الأنظمة

إن المحيط الذي يشكل معنى الحياة للأفر اد و الأزواج و الأسرة هو السياق الذي يعيش فيه الفرد نفسه والسياق أو المحيط الذي

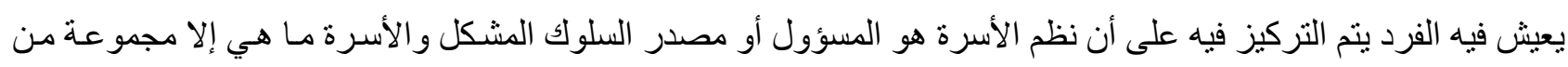
الأنظمة المشكلة وتضدنت المبادئ الأساسية للعديد من النظريات على أن الأسرة هي المشكل الأول للسلوك وتمركزت نظريـة الأنظمة على مبدأ أن أي نظام هو كل منظم وأن الكل هو أكبر من مجموع الأجز اء كما ترتكز على العديد من المبادئ التي هني تسهم في فهم كيفية السلوك الناتج من الطفل وكيفية النظام الذي يخرج بهاب(كفافي، 2010). يمكن الاستفادة من نظرية الأنظمة وتوظيفها في الإطـار النظري من خـلال فهم النظـام الذي يتبعـه الو الدين للطفل ويمارسـه الطفل ناحية والديه في نسق متبادل، فاعتبار الأنظمة هي الهيكل الأساسي لكل أسرة تمـارس التربيـة الجيدة أو التربيـة السوية

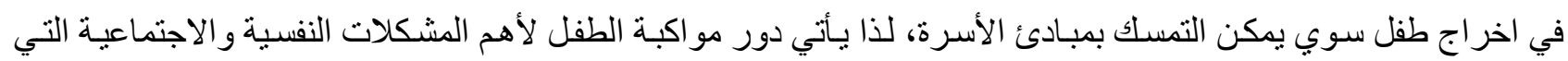
يتعرض لها الطفل في فترة كفالته. نظرية العلاج الأسري البنائي:

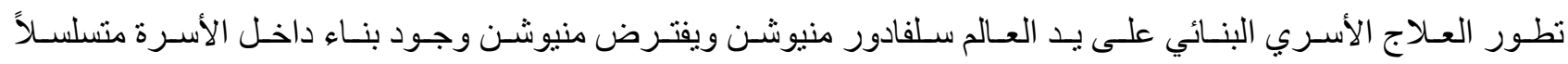

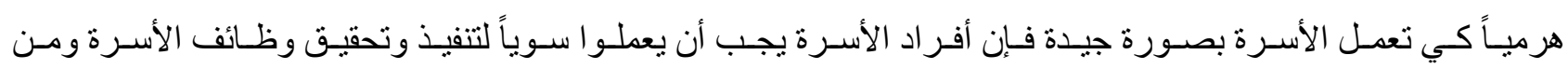
أكثر الأنظمة الفرعية شيو عاً في الأسرة هي الزوج والزوجة والو الدان و الأطفال و الإخوة(Minuchin,1974). 
نظر منيوشن في أواخر عقد الستينات إلى المشكلات من منظور أسري بدلاً من منظور فردي حيث ينظر للمعانـاة الانفعالية

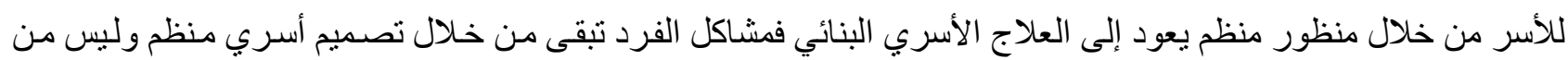
خلال المرض الثخصي وترجع أصول النظريـة البنائية في الإرشـاد الأسري إلى بدايـة الستينات من القرن العشرين والتي ارتبطت بأبحاث سلفادور منيوشن وتقوم هذه النظريـة على أسـاس أن معظم الأعر اض تتنج نتيجـة لفشـل البنـاء داخل النسق التق

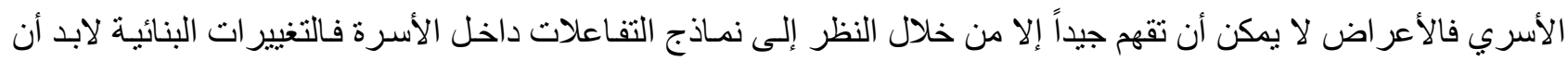
تحدث في الأسرة قبل نماذج التفاعلات داخل الأسرة فالتغييرات البنائية لابد أن تحدث في الأسرة قبل إمكانية تحسين أو خفض لهض الأعر اض الفرديـة فالنظريـة البنائيسة تنظر إلى الفرد صـاحب العرض على أنه بمثابـة مؤشر لبنـاء أسـري يعـاني من خلل

و لإحداث تغيير لدى الفرد ينبغي أن يحدث التغيير ضمن بناء الأسرة(Minuchin,Rosman \& Baker,1978). يمكن الاستفادة من نظرية العلاج الأسري البنائي بأن كل أسرة لها بنـاء هرمي تقوم عليه، من خلاله يقوي الجو انب النفسية و الاجتماعية لدى الطفل وتتحسن العلاقات بين الأبناء والآباء، لذا يأتي دور العلاج الأسري البنائي في تتكيل الأبناء بقو اعد بـد تربوية أساسية تمكن الأسرة من كفاله طفلها. نظرية الدور:

تعتقد النظرية أن سلوك الفرد و علاقاته الاجتماعية إنما تعتمد على الدور أو الأدوار الاجتماعبة التي يشغلها في المجتمع فضـلاً

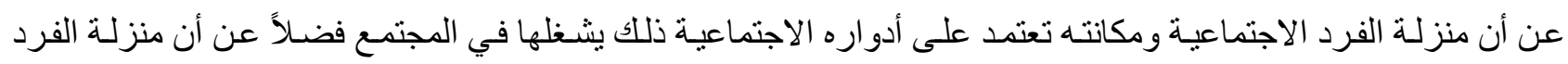
الاجتماعية ومكانته تعتمد على أدواره الاجتماعية ذلك أن الدور الذي يثـله أمـا حقوقه واجبات وحقوق اجتماعيـة فواجبات

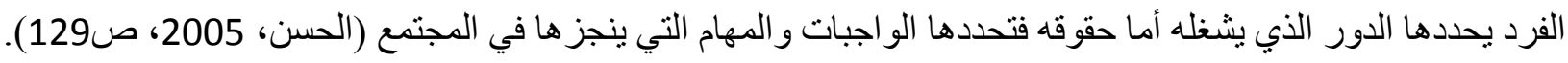
يستفاد من نظرية الدور في فهم دور كل فرد في الأسرة وزرعه ناحية أبنائهم، أما ما يمكن أن يعود على الدراسـة الحالية هو

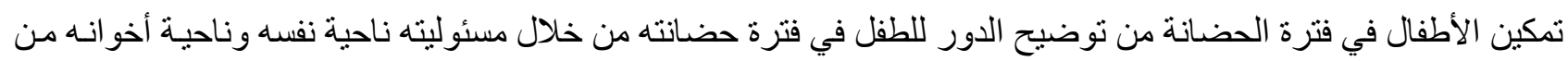
كافليه، لكي يتجنب صدام الجو انب النفسية والعزلة والانطو اء الذي تعرض له من خلال فترة انتكاسته من و الديه الذين جـاءوا به في الدنيا دون شعور بأدنى دور من المسئولية ناحية أبنائهم.

2.2 - 2. 2 الدر اسات السابقة: يتتـاول الباحث مجمو عـة مـن الدر اسـات السـابقة التـي اهتمـت بمتغيرات الدر اسـة، التو افق النفسي و الاجتمـاعي للائتـام ذوي الظروف الخاصة، وكذلك مشاكل الأسر الحاضنة مع هؤلاء الفئة خاصة بعد ما يقومون بر عايتهم لفترة ما هي مشـاكل التو افق التي تو اجه هؤ لاء الأطفال مع أسر هم، ومن هذه الدر اسات التي استطاع أن بتناولها الباحث، التالي: 1. در اسات ترتبط بمشكلات التو افق للاينام. 2. در اسات ترتبط بالأسر الحاضنة لذوي الظروف الخاصة. أولاً المحور الأول: دراسات ترتبط بمشكلات التوافق للايتام. دراسة (العمور، 2015) بعنوان: المشكلات الانفعالية والاجتماعية لاى الأيتام المراهقين في قضاء بئر السبع. هدفت الدر اسـة للتعرف إلى المشكلات الانفعاليـة و الاجتماعية لدى الأيتام المر اهقين في قضـاء بئر السبع في ضـوء متغير ات الجنس و العمر ونوع الرعاية تكونت عينة الدر اسة من (415) مر اهقاً ومر اهقة من المر اهقين الأينام في قضـاء بئر 
السبع في فلسطين للعام الدر اسي 2015 نم اختيار هم بالطريقة العشو ائية الطبقية ولتحقيق أهداف الدر اسـة تم استخدام المنهج

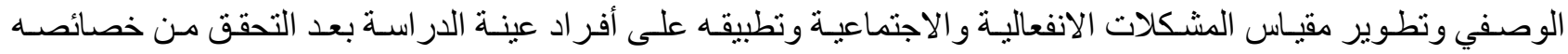
السيكومترية وأظهرت النتائج أن مدى انتشار المشكلات الانفعالية والاجتماعية لدى المر اهقين الأيتام في قضاء بئر السبع جاء ضمن المستوى المتوسط وبمتوسط حسابي بلغ 2.85 وأظهرت النتائج وجود فروق دالة إحصـائيا في مدى انتشـار المشكلات الانفعالية و الاجتماعية بـاختلاف الجنس ولصـالح الذكور ووجود فروق دالة إحصـائيأ في مدى انتشـار المشكلات الانفعالية والاجتماعية بإختلاف العمر. دراسـة (العطـار، 2019) بعنـوان: المشكلات السـلوكية لـى الأطفـال الأيتـام مـن وجهة نظر المشـرفات في ضـوء بعض المتغيرات في مركز رعاية الطفولة بمحافظة مسقط. هدفت الدر اسة إلى التعرف على أكثر من المشكلات السلوكية انتشار اً لدى الأطفال الأيتام من وجهة نظر المشرفات في ضـوء بعض المتغير ات في مركز الطفولـة في محافظـة مسقطو اتبع البحث المنهج الوصفي وقد استخدم الباحث مقيـاس المشكلات السلوكية لدى الأطفال المحرومين من البيئة الأسرية من إعداد هوبوة 2016 وبلغن عدد أفر اد العينة 44 مشرفا ومشرفة وتوصل البحث إلى أن أكثر المشكلات السلوكية انتشار اً لدى الأطفال الأيتام هي مشكلة الكذب بمنوسط 2.16 تم مشكلة فرط الحركة بمتوسط 1.95 تليها مشكلة السلوك العدو اني بمتوسط 1.93 وفي الأخير جاءت مشكلة السرقة بمنوسط 1.75 كم أظهرت النتائج عدم وجود فروق دالة احصـائية بين الذكور والإنـاث في المشكلات السلوكية ولم تظهر فروق في متغير فترة الحرمـان الو الدي وفي ضـوء نتـائج البحث تم تقديم جملـة من التوصيات و المقترحات لتفعيل عـلاج المشكلات السلوكية للأطفال بسلطنة عمان و عموم الدول العربية.

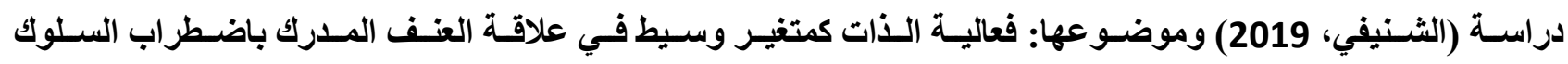
لاى الأيتام ذوي الظروف الخاصة بمدينة الرياض. هدفت الدر اسة لمعرفة دور فعاليـة الذات كتغير وسيط في علاقة العنف المدرك والاضطر ابات السلوكية لدى الأيتام ذوي الظروف الخاصة (مجهولي النسب) في مدينة الرياض، وبلغ عدد العينة (99) يتيمـا ويتيمـة، اختيروا بأسلوب الحصر الثامل و استخدمت الباحثة مقياس فعالية الذات ومقياس العنف المدرك إعداد: المشوح، 2015)، ومقياس اضطر ابات السلوك إعداد: حنورة، 1998، وتتشير أهم نتائج الدر اسة إلى وجود علاقة دالة إحصـائيا بين العنف المدرك و الاضطر ابات السلوكية لدى عينة البحث كما ظهرت فروق دالة إحصـائيا بين أفر اد عينة البحث على مقياس الاضطر ابات السلوكية ونوعها تعزي المتغير ات الديمغر افية والثخصية (الجنس- العمر - المستوى التعليمي)، كما أظهرت النتائج وجود قدرة تنبوئية لكل من فاعلية الذات و العنف المدرك باضطر اب السلوك لاى عينة البحث. دراسة (العتيبي، 2021). وموضوعها: فاعلية برنامج إرشادي انتقائي لتنمية التوافق النفسي والاجتماعي لاى الأيتام ذوي الظروف الخاصة في المرحلة الثانوية.

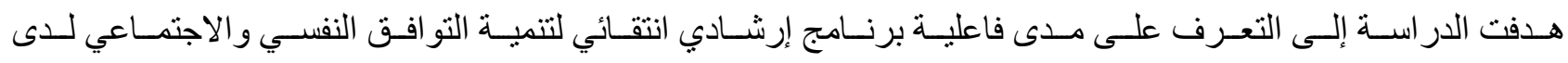

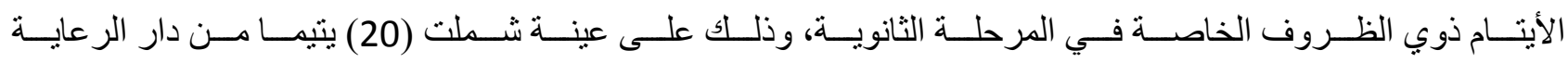
الاجتماعية بجدة ممن حصلو ا على درجات منخفضة على مقياس التو اقق النفسي و الاجتماعي، 


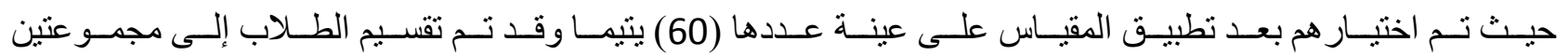

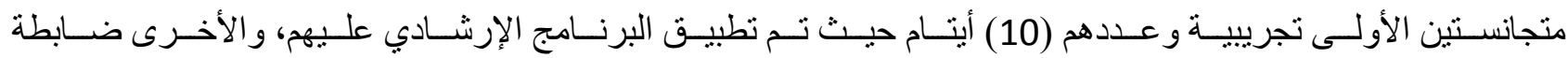

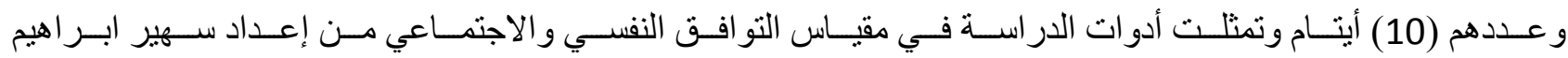
(2004) و البرنــامج الإرشـادي الانتقـائي لتنميـة التو افـق النفسـي و الاجتمـاعي مـن إعـداد الباحـث و الـذي تكـون مـن (9)

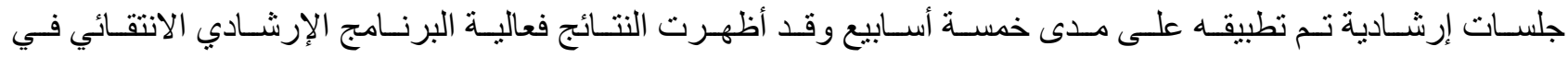

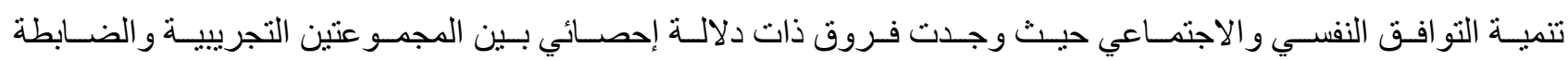
في القياس البعدي لصالح المجموعة التجريبية،

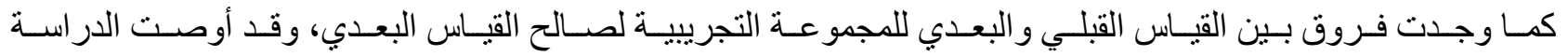

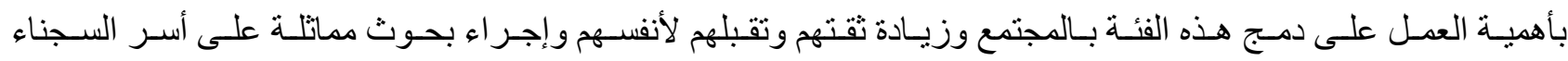
والأحداث الجائحين.

ثانيا المحور الثاني: دراسات ترتبط بالأسر الحاضنة للأيتام ذوي الظروف الخاصة. دراسة (القديري، 2019) بعنوان: العوامل الاجتماعية والاقتصـادية المؤثرة على التكيف الاجتمـاعي لأسر الأيتـام دراسـة ميدانية مطبقة على عينة من أسر الأيتام التابعة للجمعية الخيرية. هدفت الدر اسة إلى الكثف عن أثر العوامل الاجتماعية والاقتصـادية على التكيف الاجتمـاعي لأسر الأيتام واعتمدت

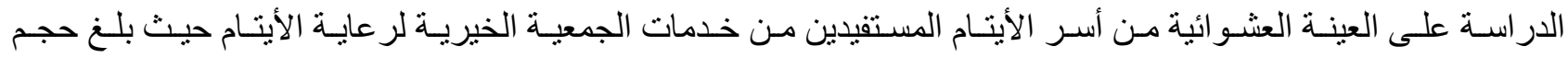
العينة(460) أسرة شاملة لفروع الجمعية الأربعة في مدينة الرياض وتم استخدام مقياس التكيف الاجتمـاعي للكثَف عن مدى التكيف الثخصـي و الأسري و المجتمعي لأسر الأيتام وتو اصلت الدراسـة إلى أن معدل التكيف الاجتمـاعي عند أسر الأيتام بشكل عام جيد وأن تكيف أفراد أسر الأيتام مـع المجتمع أفضل من التكيف الأسري ثم يليه التكيف الثخصسي ثم التكيف مـع الظروف الاقتصادية كما توصلت الدر اسة إلى أن بعض العو امل الاجتماعية وخاصة عمر الأم و الحالة الاجتماعية لها لبس لله علاقة بمعدل التكيف الاجنماعي وأن ضعف الدخل الثهري لأسر الأيتام بضعف مستوى التكيف الاجتماعي عند أفر اد الأسرة

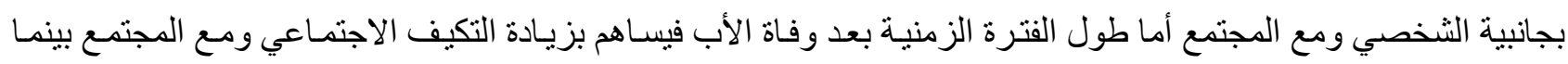

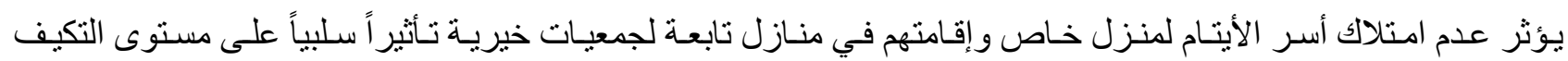

الاجتماعي مع المجنمع.

\section{دراسة (ميخائيل، 2020) بعنوان: دور الجمعيات الأهلية في رعاية الأطفال الأيتام بمصر.}

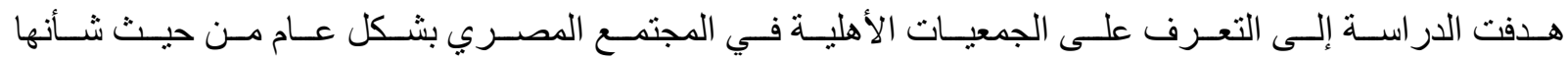

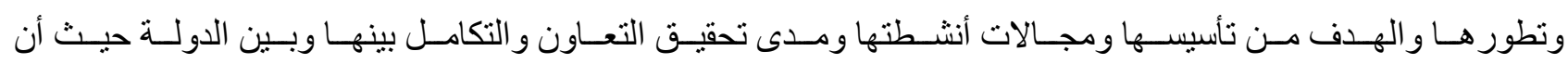

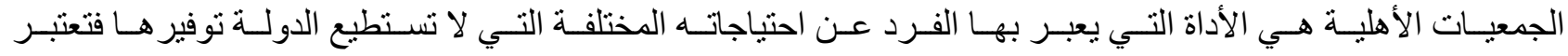

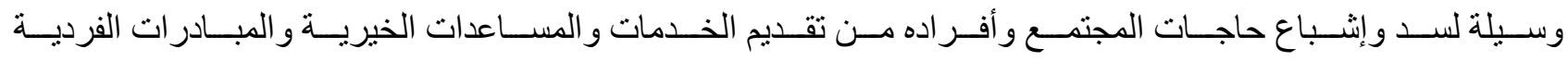

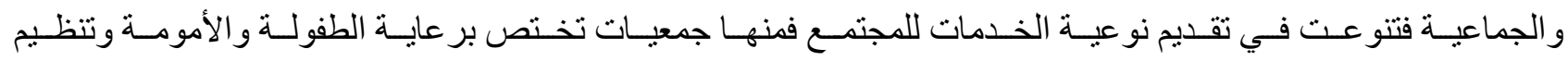

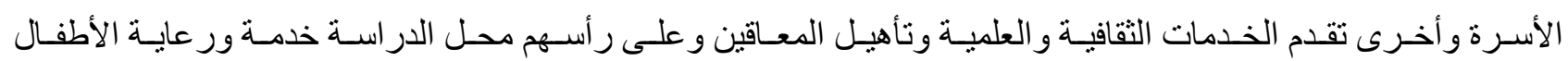




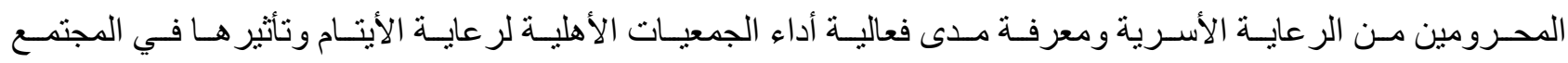

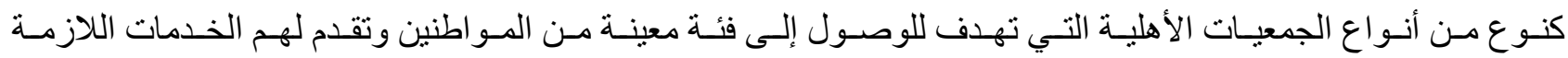
للارتقاء بهم و إثباع الاحتياجات المطلوبة.

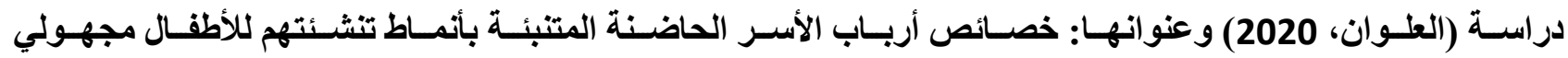
النسب في المجتمع الأردني.

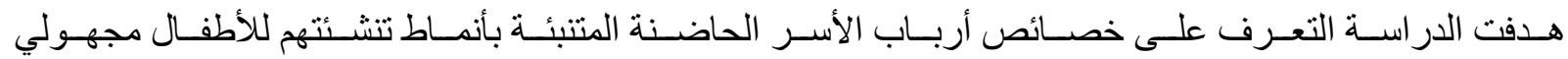

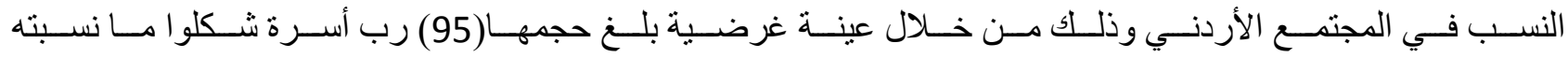

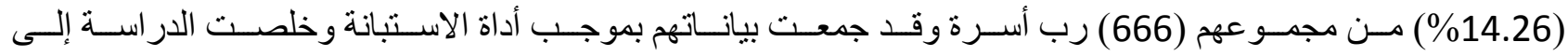

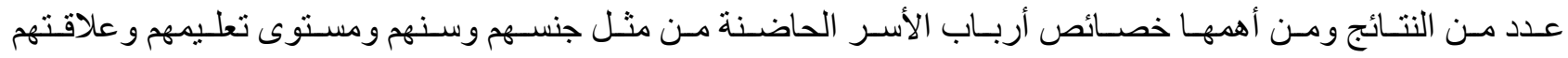

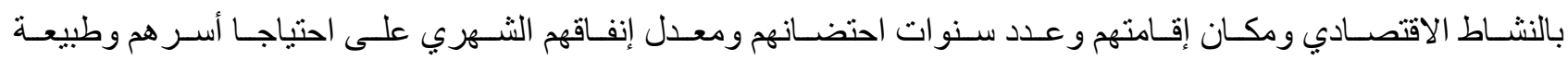

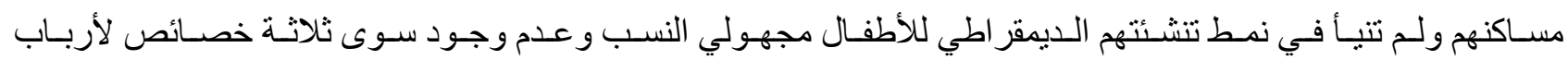

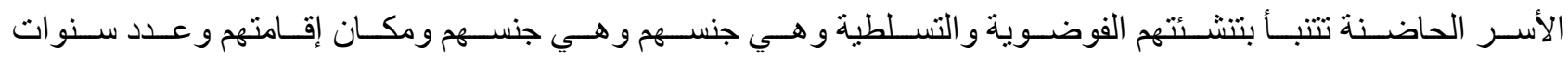

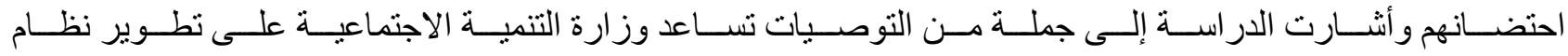

الاحتضنان.

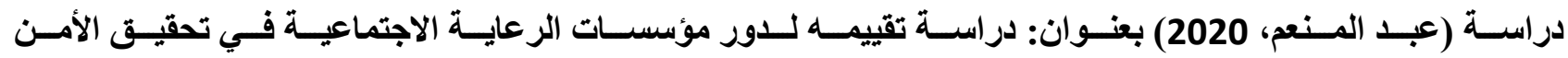
الأسري للايتام المتلحقين بها.

هدفت الدر اسة إلى تقييم دور مؤسسات الرعاية الاجتماعية في تحقيق الأمن الأسري للأيتام الملتحقين بها. وذللك لأهمية الدور الذي تقوم به مؤسسـات الرعايـة في تتشئة عدد كبير من الأطفال وتقديم العديد من الخدمات لهم سواء كانت خدمات صحية أو تعليمية او غذائية او غير ذلك من الخدمات الهامة. إلى جانب ذلك نجد ايضا أهمية دور مؤسسـات الرعايـة في خلق جو أسري للأيتام الملتحقين بها ولذلك من اجل جعلهم اشخاص صـالحون في المجتمع. وبنـاء علي ذلك تم تطبيق استمارة استبيان علي العاملين بمؤسسات الرعاية الاجتماعية بمحافظة الفيوم بعنوان "فعاليـة مؤسسـات الرعايـة الاجتماعيـة في تحقيق الأمسن الاسـري للأيتـام الملتحقين بهـا" المكونـة مـن اربعـة أبعـاد فرعيـة وهي: دور مؤسسـات الرعايـة الاجتماعيـة في توفير الخدمات الأساسية للأيتام- دور مؤسسات الرعاية الاجتماعية في توفير بيئة أسرية بديلة ـ دور مؤسسـات الرعاية الاجتماعية

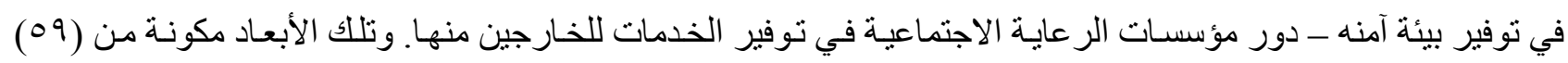
عبارة إلى جانب عمل مقابلة مع الأيتام الملتحقين بالمؤسسات الرعاية الاجتماعية وذلك من أجل معرفة دور مؤسسات الرعاية الاجتماعية في توفير الأمن الأسري لهم. التعقيب على الار اسات السابقة: بعد استعر اض الدر اسات السـابقة يمكن القول أن هنـاك تبايناً في نتائج الدر اسـات التي تناولت مشكلات التو افق للائتام ذوي الظروف الخاصة مع الأسر الحاضنة، يمكن القول أيضـاً أن الدراسـات التي أجريت حول هذا الموضـوع كانت قليلة وتتميز الدر اسة الحالية عن الدراسات السابقة في الآتي: 
اتفقت الدر اسة الحالية مع جميع الدراسات السابقة في استخدامها للمنهج الوصفي المسحي لتحقيق أهداف الدر اسة.

$$
\text { من حيث الأدوات المستخدمة: }
$$

اتفقت الدر اسة الحالية مع جميع الدراسات السابقة في استخدامها لأداة من أدوات الدراسة ألا و هي تصميم استبانة لتحقيق هدف الدراسة، ويمكن تلخيص أوجه الثبة والاختلاف و الاتفاق بين الدر اسة الحالية و الدر اسات السابقة في الآتي: أولاً: أوجه الاتفاق بين الدراسة الحالية والدراسات السابقة:

- التأكيد على توفير الاحتياجات النفسية و الاجتماعية للأطفال بسبب المشكلات اللا نو افقية التي يمكن التعرض لها. - الاشتر الك في إعداد أداة للتعرف على مشكلات التو افق من وجهة نظر الأسر الحاضنة للأطفال الأيتام ذوي

$$
\text { - استخدام المنهج الوصفي المسحي. }
$$

- أهمية استخدام الاستر اتيجيات الحديثة المتعلقة بالايتام مع روئية المملكة العربية السعودية. ثانياً: أوجه الاختلاف بين الاراسة الحالية والاراسات السابقة:

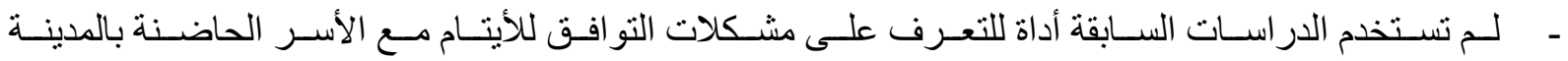
المنورة.

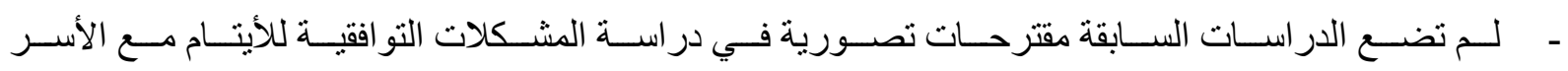

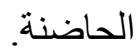
- لم تتطرق الدر اسات السابقة إلى ربط الأسر الحاضنة بالأيتام. ثالثثاً: أوجه الاستفادة من الاراسات السابقة: - شملت بعض الدراسات السابقة على مفهوم التو افق و الأيتام و الأسر الحاضنة. ـ استخدمت الدر اسات السابقة أداة الاستبانة في جمع البيانات ممـا قد يسـاعد على جمع المعلومـات حول المشكلات الخاصة بالأيتام سواء النفسية أو الاجتماعية.

- استخدمت بعض الدراسات السابقة المنهج الوصفي المسحي ممـا سيعطي الدر اسـة الحالية رؤيـة شـاملة عن كيفية استخدام هذا المنهج بصورة أفضل. - استخدمت الدر اسـات السـابقة أسـاليب إحصـائية متنوعـة ممـا يثري الدراسـة الحاليـة في سبل استخدام الأسـالبب الإحصائية المناسبة. ما يميز هذه الاراسة عن الدراسات السابقة:

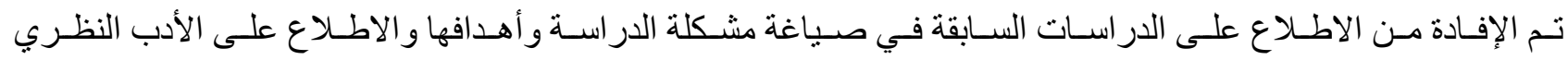

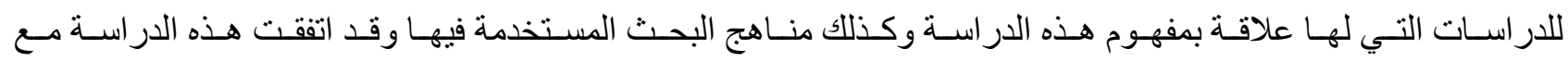

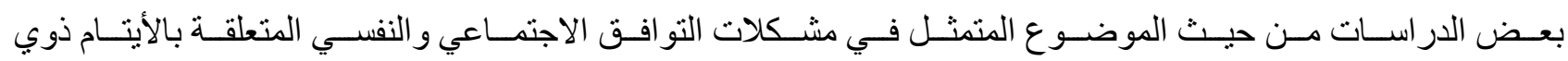




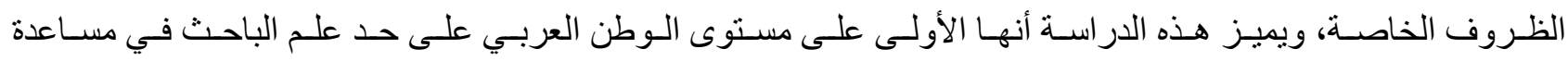
تحديد المشكلات التو افقية للأيتام ذوي الظروف الخاصة بالمدينة المنورة.

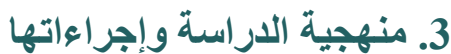

يعرض الباحث الجزء المنهجي الخاصـة بـأدوات الدراسـة التي استخدمت في التطبيق الميداني، حيث يتم عرض المنهج المستخدم ومجتمع الدر اسة و العينة المأخوذة من المجتمع مع شرح الخصـائص للعينـة الأساسية وصدق وثبـات أداة الاستبانة التي قام الباحث باعدادها في ضوء الدر اسات السابقة والإطار النظري.

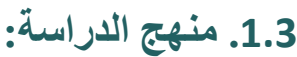

بما أن هذه الدر اسة استهدفت الكثف عن "مشكلات توافق الأيتام ذوي الظروف الخاصة مع الأسر الحاضنة: دراسة مطبقة على الأسر الحاضنة في المدينة المنورة"، استخدم الباحث لتحقيق اهداف الدراسة المنهج الوصفي المسحي من اجل الكثف عن مشكلات نو افق الأيتام ذوي الظروف الخاصة مع الأسر الحاضنة، من وجهة نظر الأسر الكافلة.

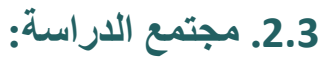

يتكون مجتمع الدر اسة من جميع الأسر الكافلة بالمدينة المنورة والبالغ عددهم (600) أسرة خلال الفصل الثاني من العام

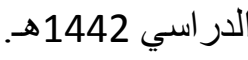

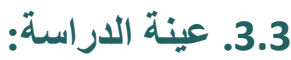

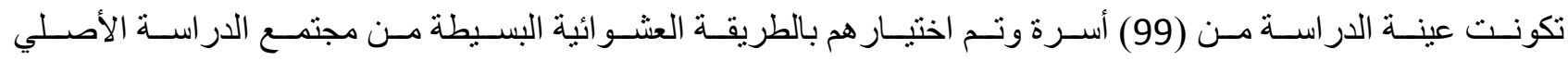
وبلغت نسبتهم (16.5\%) ويوضح الجدول (1) خصائص أفراد عينة الدراسة.

$$
\text { - مصف الاستبانه: }
$$

تكون الاستبانه من مجمو عة من العبار ات و عددها (30) عبارة تشمل محورين مشكلات التو افق النفسي والاجتماعي للأيتام ذوي الظروف الخاصة من وجهة نظر الأسر الكافلة بالمدينة المنورة. - - تصحيح الأداة:

تم تصحيح أداة الدر اسة من خلال استجابات الدر اسة حيث تتكون بدائل الاستبيان من (مو افق بثدة- مو افق- غير متأكد- غير مو افق- غير مو افق بشدة) ودرجاته بالترنيب كالتالي(5-4-3-2-1) حيث تأخذ نتائج البدائل الدرجة لكل استجابة وينم تجميع الاستجابات للمفحوص لتكون درجة كل أسرة من الأسر الكافلة والدرجة الكلية=150 عدد مفردات(30) في حاصل ضرب الدرجة الكبرى لاستجابة العبار ات. 


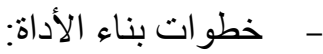

بناء أداة الدر اسة بالرجوع إلى الأدبيات و الدراسات السابقة ذات العلاقة بموضوع الدراسة حيث تكونت الاستبانة الموجهة إلى عينة من الأسر الكافلة التابعيين لإدارة الأسر الكافلة لذوي الظروف الخاصة بالمدينة المنورة في العام الدراسي 1442هـ وتكونت صورتها المبدئية من (30) عبارة، وبعد تحكيم الاستبانة وإضافة وتعديل بعض العبار ات بناء على إجماع نفس النسبة على ذللك، إلى أن بلغت عبار ات الاستبانة في صورتها النهائية (30) عبارة مقسمة إلى جز أين: الجزء الأول: تتاول البيانات الأولية الخاصة بأفراد عينة الدراسة مثل:

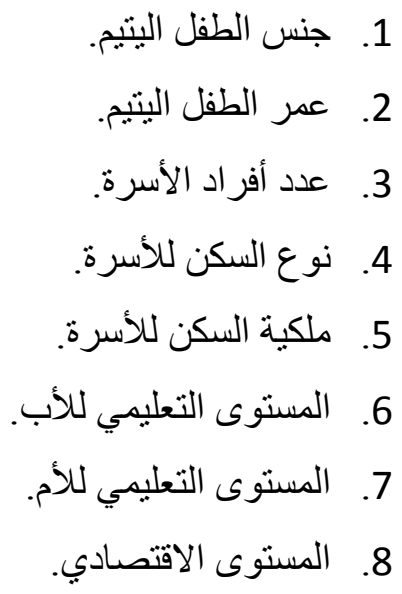

الجزء الثاني: وتكون من (30) عبارة مقسمة على محورين رئيسين كما يلي:

أو لاً: مشكلات التو افق النفسي للأيتام ذوي الظروف الخاصة، وتككن من (15) عبارة. ثانياً: مشكلات التو افق الاجتماعي للايتام ذوي الظروف الخاصة، وتكون من (15) عبارة. صدق أداة الدراسة: صدق الاستبانة يعني التأكد من أنها سوف تقيس ما أُعدت لقياسه ولقد قام الباحث بالتأكد من صدق الاستبانة من خلال ما يلي:

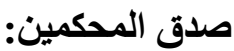

طُلب من المحكمين إبداء الر أي حول مدى وضوح العبار ات ومدى ملاءمتها لما وضعت لأجله، ومدى مناسبة العبار ات للمحور الذي تتنمي إليه، مع وضع التعديلات والاقتر احات التي يمكن من خلالها تطوير الاستبانة، وتم المو افقة على عبار ات الاستبانه و أخذ بها كاستبانه صالحه لقياس متغير ات الدراسة، مشكلات التو افق النفسي و الاجتماعي لذوي الظروف الخاصة بالمدينة المنورة. الاتساق الاخلي: بعد التأكد من الصدق الظاهري لأداة الدر اسة قام الباحث بنطبيقها ميدانيًا على عينة الدارسة، ثم قامت الباحثة بحساب معامل الارتباط بيرسون لمعرفة الصدق الداخلي للاستبانة، حيث تم حساب معامل الارنباط بين درجة كل عبارة من عبار ات الاستبانة بالدرجة الكلية للاستبانه، كما توضح ذلك الجداول التالية. 
جدول (1) معاملات ارتباط بيرسون لعبارات المحور الأول بالدرجة الكلية

\begin{tabular}{|c|c|c|c|}
\hline الارجة الكلية للمحور & رقم العبارة & الدرجة الكلية للمحور & رقم العبارة \\
\hline$* 0,189$ & 11 & $* 0144$ & 1 \\
\hline$* * 0,561$ & 12 & $* * 0,477$ & 2 \\
\hline$* * 0,491$ & 13 & $* * 0,457$ & 3 \\
\hline$* * 0,406$ & 14 & $* * 0,555$ & 4 \\
\hline$* * 0,311$ & 15 & $* 0,137$ & 5 \\
\hline & & $* * 0,445$ & 6 \\
\hline & & $* * 0,508$ & 7 \\
\hline & & $* 0,130$ & 8 \\
\hline & & $* * 0491$ & 9 \\
\hline & & $* * 0406$ & 10 \\
\hline
\end{tabular}

يلاحظ *** دال عند مستوى الدالة 0,01 فَأقّل

جدول (2) معاملات ارتباط بيرسون لعبارات المحور الثاني بالدرجة الكلية

\begin{tabular}{|c|c|c|c|}
\hline الارجة الكلية للمحور & رقم العبارة & الارجة الكلية للمحور & رقم العبارة \\
\hline$* 0,595$ & 11 & $* 0133$ & 1 \\
\hline$* * 0,543$ & 12 & $* * 0,644$ & 2 \\
\hline$* * 0,623$ & 13 & $* * 0,281$ & 3 \\
\hline$* * 0,543$ & 14 & $* * 0,313$ & 4 \\
\hline$* * 0,258$ & 15 & $* 0,255$ & 5 \\
\hline & & $* * 0,412$ & 6 \\
\hline & & $* * 0,623$ & 7 \\
\hline & & $* 0,725$ & 8 \\
\hline & & $* * 0634$ & 9 \\
\hline & & $* * 0714$ & 10 \\
\hline
\end{tabular}

يلاحظ ** دال عند مستوى الدالة 0,01 فَأقّل 
جدول (3) معاملات ارتباط بيرسون لعبارات المحورين بالدرجة الكلية

\begin{tabular}{|c|c|c|c|}
\hline اللارجة الكلية & الارجة الكلية للمحور & الارجة الكلية للمحور & المحاور \\
\hline$* * 0902$ & $* * 0693$ & 1 & الارجة الكلية للمحور الأول \\
\hline$* * 0932$ & 1 & $* * 0683$ & اللارجة الكلية للمحور الثاني \\
\hline 11 & $* * 0932$ & $* * 0902$ & الارجة الكلية للمحورين \\
\hline
\end{tabular}

يلاحظ ** دال عند مستوى الدلالة 0,01 فأقّل

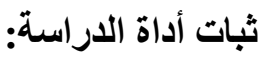

\section{- - مريقة معامل ألفا كرونباخ:}

قام الباحث بحسـاب ثبات الاستبيان باستخدام معامل ألفا كرونباخ للمقياس وجاءت النتائج قيمـة معامل ألفا كرونباخ للمقياس ككل (0.848) و هذا يعني أن الاستبيان يتمتع بدرجة جيدة من الثبات.

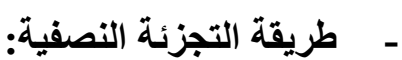

قام الباحث بتجزئة فقر ات المقياس إلى نصفين؛ الفقرات الفرديـة في مقابل الفقرات الزوجيـة، وتم استخدام معامل ارتبـاط "بيرسون" (Pearson's coefficient) في حسـاب مـدى الإرتبـاط بين درجـات النصفين الأول والثناني، وجرى لئه تصحيح الطول باستخدام معادلة "سبيرمان وبر اون" (Spearman-Brown)، وكانت قيمة معامل الثبات بهذه الطريقة (0.811) و هي قيمة تؤكد على أن استبيان مشكلات التو افق لذوي الظروف الخاصـة يتمتع بدرجة مرتفعة من الثبات يصلح معها استخدامه كأداة لجمع البيانات في الدر اسة الحالية. خطوات تطبيق الار اسة: يمكن للباحث أن يعرض باختصار مـا قام بـه أثناء فترة البحث العلمي بدايـة من الإطلاع وحتى استخلاص النتائج

$$
\text { و التوصيات و المقترحات: }
$$

1- الاطلاع على مزيد من الكتب و الدر اسات السابقة و الاستفادة منها وتلخيص بعض الأجز اء ثم تدوينها لعدل الإطـار

$$
\text { النظري و الدر اسات السابقة. }
$$

2- قر اءة المزيد من المناهج وخاصة منهج الدر اسة (المنهج الوصفي)، ثم تحديد مجتمع الدر اسـة و عينتها التـي يمكن

التطبيق عليها.

3- إعداد استبانه يشتمل على محورين مشكلات التو افق النفسي و الاجتماعي لذوي الظروف الخاصة. 4- تطبيق الاستبانه على عينة الدر اسة بالمدينة المنورة. 5- تفريغ تللك البيانات وترميز ها ثم رفعها على برنامج المعالجات الاحصائية 6- استخلاص تلك النتائج وتفسير ها ومناقتنها و عرض النتائج النهائية. 7- استخر اج التوصيات و المقترحات المناسبة وفقاً لنتائج الدراسة وموضو وعها. 


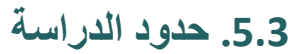

• الحدود الموضوعية: مشكلات تو افق الأيتام ذوي الظروف الخاصة مع الأسر الكافلة بالمدينة المنورة.

$$
\text { • الحدود الزمنية: تم تطبيق الدراسة في عام 1442ه. }
$$

• الحدود البشرية: تم اختيار العينة من الأسر الكافلة للأطفال الأيتام التابعين لإدارة الأسرة الكافلة بالمدينة المنورة.

• الحدود المكانية: طبقت الدر اسة مع الأسر التابعين لإدارة الأسر الكافلة بالمدينة المنورة.

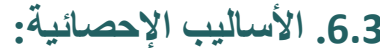

لتحقيق أهداف الدر اسة وتحليل البيانات التي تم جمعها، فقد نم استخدام العديد من الأساليب الإحصائية المناسبة باستخدام الحزم الإحصائية للعلوم الاجتماعية Statistical Package for Social Sciences و التي يرمز لها اختصـارًا بالرمز (SPS).

وذللك بعد أن تم ترميز و إذخال البيانات إلى الحاسب الآلي، ولتحديد طول خلايا المقياس الخماسي (الحدود الدنبا والعليا) المستخدم في محاور الدر اسة، تم حساب المدى (5-1=4)، ثم تقسيمه على عدد خلايا المقياس للحصول على طول الخلية الصحيح أي (5/4= 0,80)، بعد ذلك تم إضافة هذه القيمة إلى أقل قيمة في المقياس (أو بداية المقياس و هي الواحد الصحيح) وذلك لتحديد الحد الأعلى لهذه الخلية، و هكذا أصبح طول الخلابيا كما يأتي:

ـ من 1 إلى أقل من 1,80 يمثل درجة (غير مو افق بشدة) نحو كل عبارة باختلاف المحور المر اد قياسه.

ـ من 1,80 إلى أقل من 2,60 يمثل درجة (غير مو افق) نحو كل عبارة باختلاف المحور المر اد قياسه.

ـ من 2,60 إلى أقل من3,40 يمثل درجة (محايد) نحو كل عبارة باختلاف المحور المر اد قياسه.

ـ من 3,40 إلى أقل من4,20 يمثل درجة مو افقة (أو افق) نحو كل عبارة باختلاف المحور المر اد قياسا.

ـ ـن 4,20 إلى 5,0 يمثل درجة مو افقة (أو افق بشدة) نحو كل عبارة باختلاف المحور المر اد قياسه.

\section{وبعد ذلك تم حساب المقاييس الإحصائية التالية:}

$$
\text { 1. حساب المنوسطات و الانحر افات المعيارية لعبار ات الاستبيان. }
$$

2. معامل ارتباط بيرسون (Pearson Correlation Coefficient): للتحقق من صدق أداة الدر اسـة، وذلك بإيجاد

العلاقة بين الدرجة الكلية للمحور الذي تنتمي إليه العبار ات.

3. معامل ألفا كرونباخ (Cronbach's alpha): للتحقق من ثبات أداة الدر اسة.

4. تم استخدام اختبار كروسكال والاس (Kruskal Wallis): للتعرف على الفروق بين متوسطات استجابات أفر اد عينة

الدر اسة وفقًا لمتغيرات عمر ولي الأمر، مستوى الدخل، المستوى التعليمي، جنس الطفل. 
4. الاراسة الميدانية ومناقشته وتفسير النتائج.

يتتاول هذا الفصل عرضًا لخصائص أفر اد الدر اسة والنتائج للار اسة الميدانية ومناقتتها، من خلال إجابات أفر اد عينة الدراسة عن أسئلة الدر اسة من خلال العرض لاستجاباتهم على محاور ها بصفة مجملة وذللك على النحو التالي:

خصائص أفراد عينة الدراسة:

أولاً: الخصائص للطقل اليتيم:

اتصفت أفر اد عينة الدر اسة بعدد من الخصائص في ضوء متغير ات الدر اسة يمكن توضيحها فيما يلي:

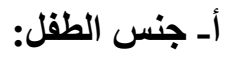

جدول (4) توزيع أفراد عينة الدراسة وفقًًا لمتفير جنس الطقل.

\begin{tabular}{|c|c|c|}
\hline النسبة المئوية & التكرارات & جنس الطقل \\
\hline$\% 48.5$ & 48 & ذكر \\
\hline$\% 51.5$ & 51 & أنثى \\
\hline$\% 100$ & 99 & الإجمالي \\
\hline
\end{tabular}

يتضح من الجدول المبين أعلاه أن جنس الطفل اليتيم (ذكور / إناث) بلغ عدد الذكور= 48.5 بنسبة 40\% من العينة الكلية بينما بلغ عدد الإناث 51 بنسبة 51.5٪ وهذا يعني أن نسبة الإناث المشتركين في الاستجابات على الاستبيان أكثر من الذكور.

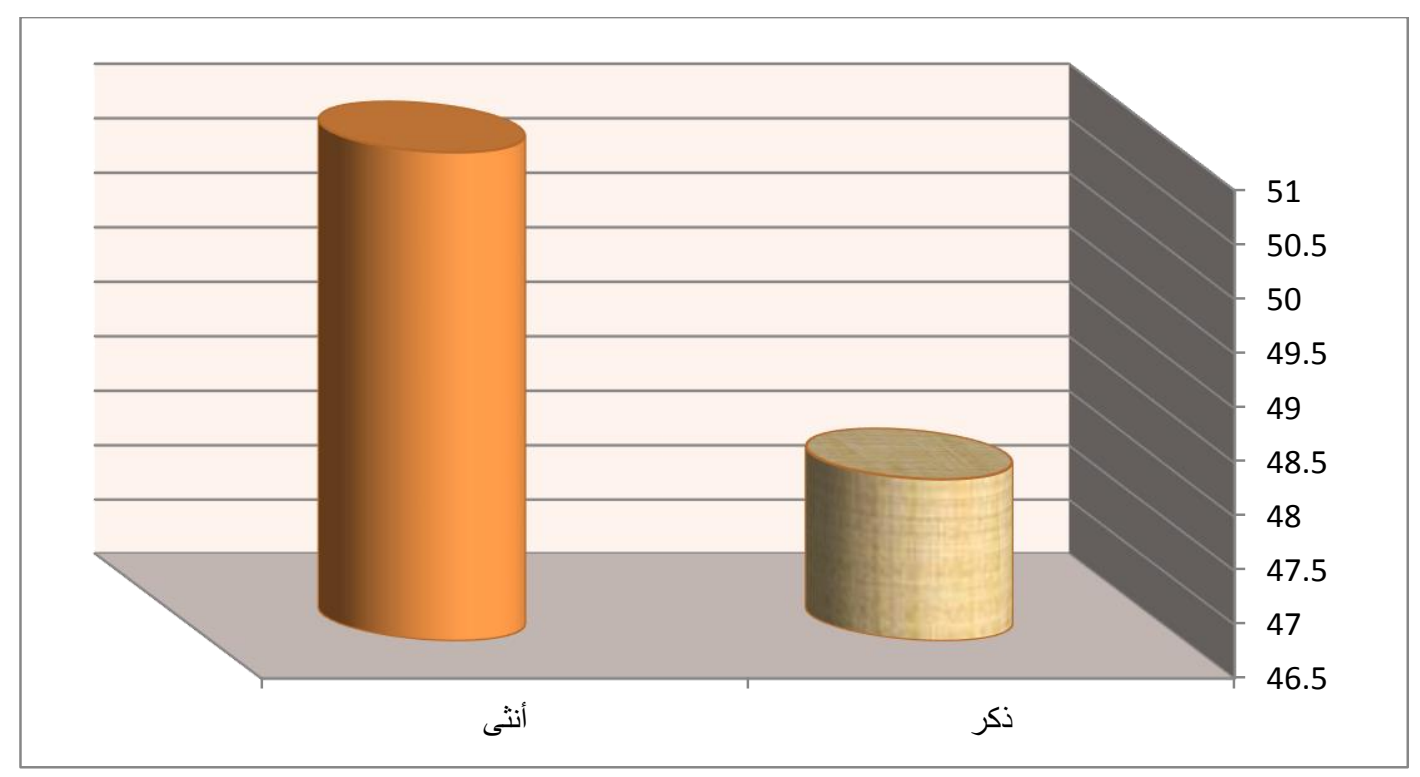

شكل (1) يبين نسب توزيع عينة الدراسة وفقًا لمتغير الجنس للطقل اليتيم.

يتضح من الثكل السابق أن نسبة الإنـاث أعلى من نسب الذكور، حيث بلغت نسبة الإنـاث 51.5٪ بينما بلغت نسبة الذكور 
بـ عمر الطفل اليتيم:

اتصفت أفر اد عينة الدر اسة بعدد من الخصائص في ضوء متغير ات الدر اسة يمكن توضيحها فيما يلي: جدول (5) توزيع أفراد عينة الدراسة للطفل اليتيم وفقاً لمتفير عمر الطقل.

\begin{tabular}{|c|c|c|}
\hline النسبة المئوية & التكرارات & عمر الطقل \\
\hline$\% 20$ & 24 & من 3- 6 سنو ات \\
\hline$\% 9.2$ & 11 & من 6- 8 سنوات \\
\hline$\% 17.5$ & 21 & من 8- 10 سنوات \\
\hline$\% 35.8$ & 43 & من 10 -12 سنة \\
\hline$\% 100$ & 99 & الإجمالي \\
\hline
\end{tabular}

يتضح من الجدول السابق أن عمر الطفل اليتيم الذي تراوح أعماره من 3- 12 سنة حيث كان الأطفال الأيتام الذين بلغو ا من 3 - 6 سنو ات عددهم =24 بنسبة 20٪ بينما بلغ عدد الأطفال الذين يبلغ أعمار هم من 6-8 سنوات = 11 طفل بنسبة 9.2\% وجاء الأطفال الذين أعمار هم من 8- 10 سنو ات=21 بنسبة 17.5٪ و أخيراً الأطفال الذين ييلغ أعماره من 10- 12 سنة = 43 بنسبة 35.8\%

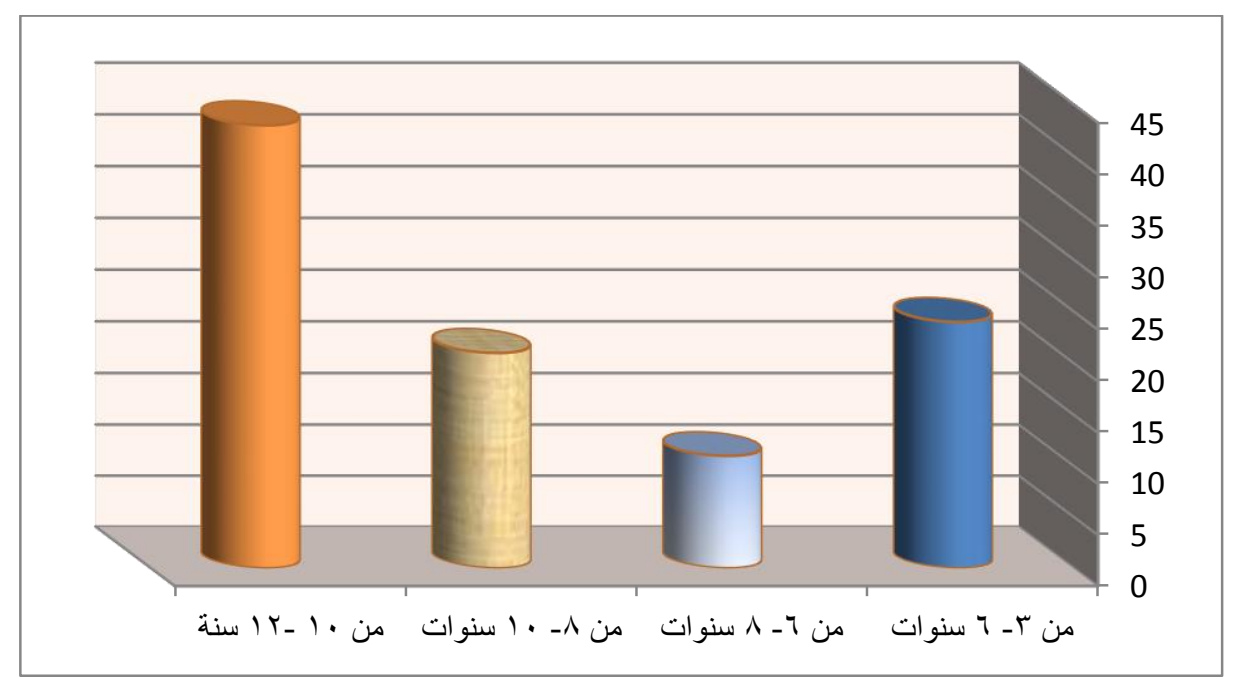

شكل (2) يبين نسب توزيع عينة الدراسة وفقًا لمتغير العمر الحالي للطقل اليتيم.

يتضح من الثكل السابق أن عدد الأعمار من 10-12 سنة هم أكبر نسبة تم مشاركتهم في الدراسة من خلال استجاباتهم حيث كانت نسبتهم 35.8\% بينما عدد الأطفال الذين بلغو ا أعمار هم من 3-6 سنوات هم أقل نسبة نم اشتر اكها في العينة. 
ثانياً: الخصائص للأسرة:

أ ـ ـ عدد أفراد الأسرة:

جدول (6) توزيع أفراد عينة الدراسة وفقًا لمتغير عدد أفراد الأسرة

\begin{tabular}{|c|c|c|}
\hline النسبة المئوية & التكرارات & عدد أفراد الأسرة \\
\hline$\% 45.8$ & 55 & من 1 إلى 3 أفراد \\
\hline$\% 24.2$ & 29 & من 4 إلى 6 أفراد \\
\hline$\% 12.5$ & 15 & 7 أفر اد فأكثر \\
\hline$\% 100$ & 99 & الإجمالي \\
\hline
\end{tabular}

بينما وفي عدد أفر اد الأسرة الكافلة كان عدد الذين اشتركوا في العينـة وييلّغ عددهم من 1- 3 أفر اد= 55 بنسبة 45.8٪ بينما عدد الأفر اد الأسرة الذين يبلغ عدد أفر ادها من 4- 6 أفر اد=29 بنسبة 24.2٪ و عدد أفر اد الأسرة الذين بلغ أفر ادها أكثر من 7 أفر ادها =15 بنسبة 12.5\%

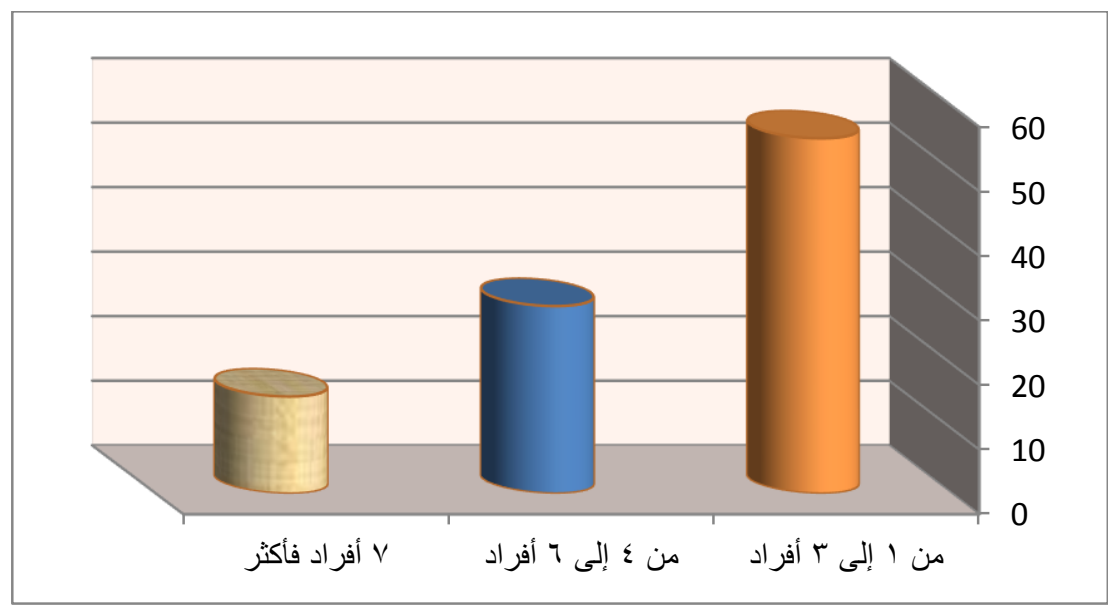

شكل (3) يبين نسب توزيع عينة الدراسة وفقًا لمتفير عدد أفراد الأسرة.

يتضح من الثكل السابق أن عدد أفر اد الأسر من 1-3 يبلغ عدده55 حيث يعد هم الأكثر عدد في عينة الدراسـة للأسـر الكافلـة بينما الأسر التي تزيد عن 7 أفر اد فأكثر هم أقل الأسر الكافلة للأطفال الأيتام.

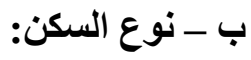

جدول (7) توزيع أفراد عينة الدراسة وفقًا لمتغير نوع السكن.

\begin{tabular}{|c|c|c|}
\hline النسبة المئوية & التكرارات & نوع السكن \\
\hline$\% 55$ & 66 & ملك ملك \\
\hline \%13.3 & 16 & أيجار \\
\hline$\% 100$ & 99 & الإجمالي \\
\hline
\end{tabular}


وفي نوع السكن للأسر الكافلة كان الذين يملكون سكناً (ملك) عددهم=66 بنسبة 55٪ بينما كانوا الذين يعيشون في إيجار عددهم= 16 بنسبة 13.3\%، و هذا يعني أن نسبة الكافلين الذين يملكون سكناً ملك هم النسبة الأكبر.

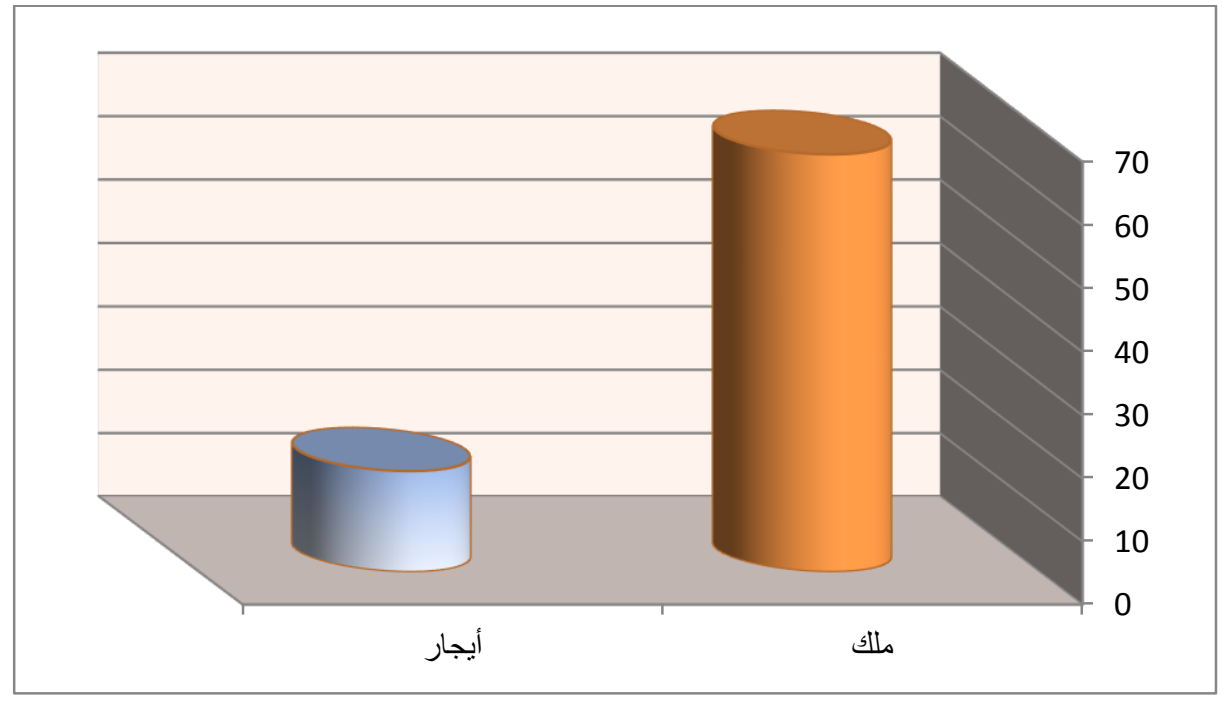

شكل (4) يبين نسب توزيع عينة الاراسة وفقًا لمتفير نوع السكن.

يتضح من الثكل السابق أن الأسر الكافلة للطفل اليتيم نسبة الذين يملكون منازل أكبر من الذين يعيشون بالإيجار. ج - مستوى التعليم للأب:

جدول (8) توزيع أفراد عينة الاراسة وفقًا لمتغير المستوى التعليمي للأب او الحاضن

\begin{tabular}{|c|c|c|}
\hline النسبة المئوية & التكرارات & المستوى التعليمي للأب \\
\hline$\% 5.8$ & 7 & لا يقر أ ولا يكتب \\
\hline$\% 11.7$ & 14 & ابتدائي \\
\hline$\% 12.5$ & 15 & متوسط \\
\hline$\% 31.7$ & 38 & ثانوي \\
\hline$\% 20.8$ & 25 & جامعي وما فوق \\
\hline$\% 100$ & 99 & الإجمالي \\
\hline
\end{tabular}

يتضح من الجدول السـابق المستوى التعليمي للأب للأسـر الكافلـة كـان الآبـاء الذين لا يقر أو لا يكتب = 7 بنسبة 5. 5. بينمـا الحاصلين على ابتدائي= 14 بنسبة 11.7٪ و الحاصلين على تعليم متوسط عددهم= 15 بنسبة 12.5٪ و الحاصلين على تعليم ثانوي=38 بنسبة 31.7٪ و الذين حصلو ا على تعليم جامعي وما فوق=25 بنسبة 20.8٪. 


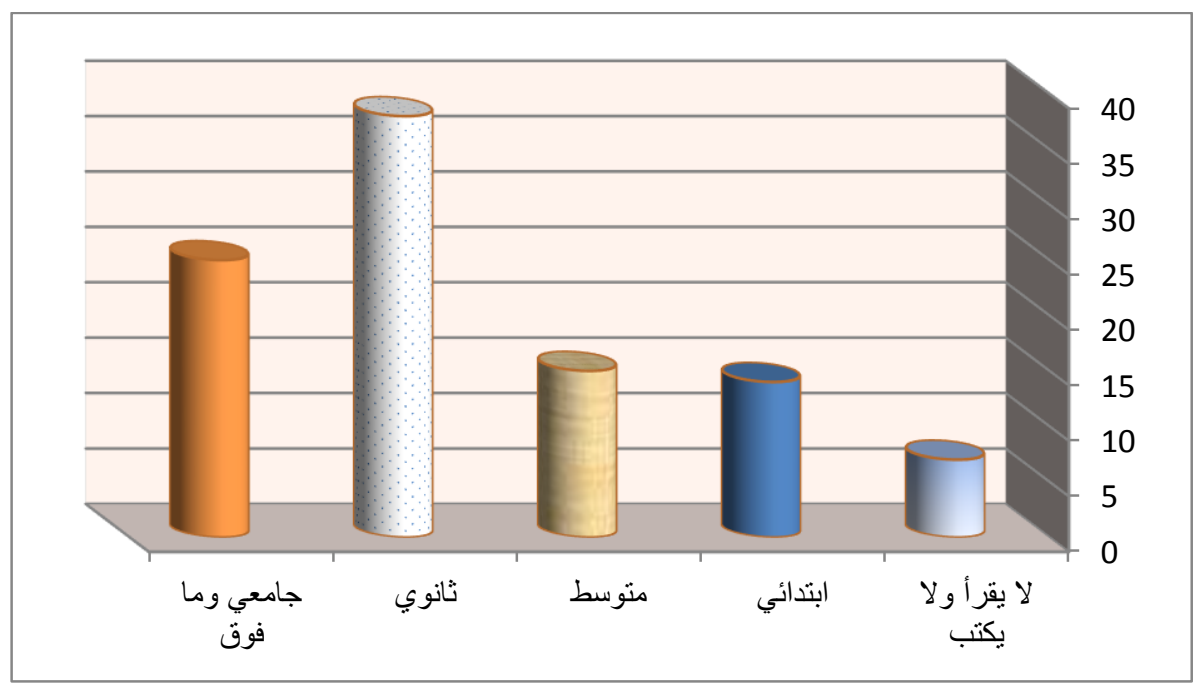

شكل (5) يبين نسب توزيع عينة الاراسة وفقًا لمتغير مستوى تعليم الأب.

يتضـح مـن الثــكل السـابق أن الآبـاء الحاصـلين علـى الثانويـة العامـة يثـغلون نسـبة كبيـرة 31.7٪ مـن عينـة الدر اســة بينما النسبة الأقل من الذين لا يجيدون القر اءة والكتابة فهي قليلة حيث بلغت 5.8٪.

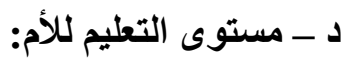

جدول (9) توزيع أفراد عينة الدراسة وفقًا لمتفير المستوى التعليمي للام او الحاضنة

\begin{tabular}{|c|c|c|}
\hline النسبة المئوية & التكرارات & المستوى التعليمي للأم \\
\hline$\% 5$ & 6 & لا يقر أ ولا يكتب \\
\hline$\% 9.2$ & 11 & ابتدائي \\
\hline$\% 15.8$ & 19 & متوسط \\
\hline$\% 24.2$ & 29 & ثانوي \\
\hline$\% 28.3$ & 34 & جامعي وما فوق \\
\hline$\% 100$ & 99 & الإجمالي \\
\hline
\end{tabular}

يتضح من الجدول السابق أن مستوى تعليم الأم الكافلة اللائي لا يقرؤون و لا يكتبون عددهم=6 بنسبة 5\% بينما كان الحاصلات على ابتدائي =11 بنسبة 9.2٪ و الحاصـلات على تعليم متوسط عددهم = 19 بنسبة 15.8٪ و اللائي حصلو ا على تعليم ثنانوي= 29 بنسبة 24.2٪ بينما اللائي حصلو ا على تعليم جامعي وما فوق= 34 بنسبة 28.3٪. 
الهجلة الدولية لنشر البحوث والدراسات

International Journal of Research and Studies Publishing ISSN: 2709-7064
الهجلد الثالث - الإصدار الثامن والعشرون تأريخ الإصدار: 20 فبراير 2022 م

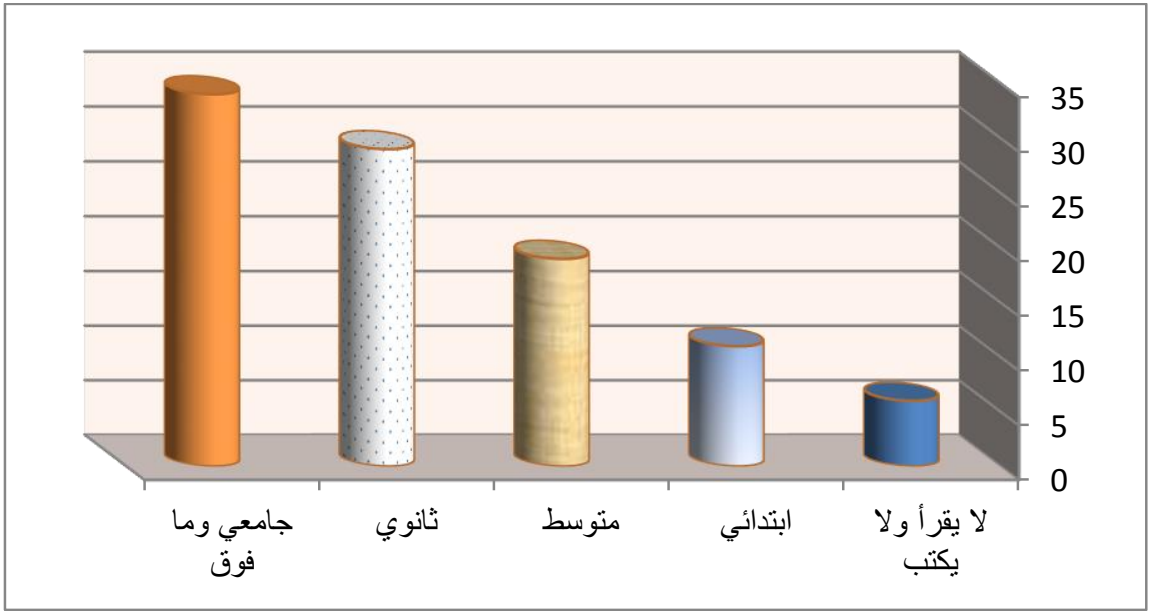

شكل (6) يبين نسب توزيع عينة الدراسة وفقًا لمتغير التعليم للأم.

يظهر من الثكل السابق أن الأمهات الحاصلات على مستوى تعليم جامعي وما فوق هم الأكثر عدداً في عينة الدراسـة عكس مستوى تعليم الآبـاء كان أكثر من الحاصلين على الثانويـة العامـة بينمـا يظهر الأمهات اللائي لا يجيدون القراءة و الكتابـة هن الأقل في الاستجابات. ه - مستوى الاخل للأسرة:

جدول (10) توزيع أفراد عينة الاراسة وفقًا لمتغير مستوى دخل الأسرة.

\begin{tabular}{|c|c|c|}
\hline النسبة المئوية & التكرارات & مستوى دخل الأسرة \\
\hline$\% 28.3$ & 34 & أقل من 5000 ربال \\
\hline$\% 29.2$ & 35 & من 5000 ربال إلى 10000 ريال \\
\hline$\% 15$ & 18 & من 10000 ربال إلى 15000 ربال \\
\hline$\% 10$ & 12 & أكثر من 15000 ربال \\
\hline$\% 100$ & 99 & الإجمالي \\
\hline
\end{tabular}

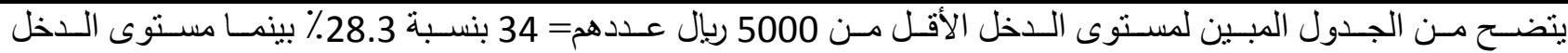
مـن 5000 إلـى 10000 ربال كــان عـددهم 35 بنسـبة 29.2٪ وفـي مسـتوى الــخل مـن 10000 إلـى 15000 ربال عددهم 18 بنسبة 15\% و الأكثر من 15000 ربال عددهم 12 بنسبة 10٪. 


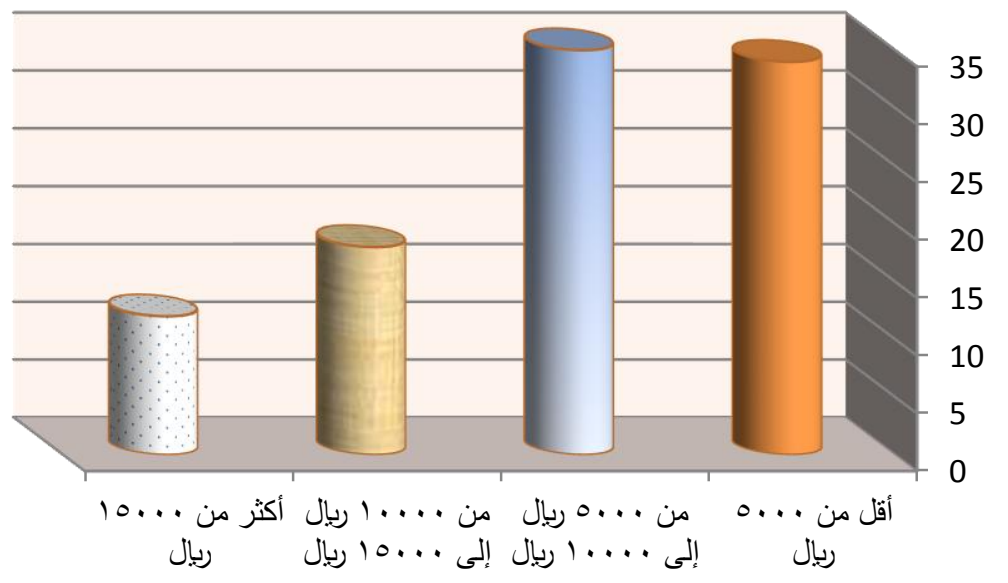

شكل (7) يبين نسب توزيع عينة الدراسة وفقًا لمتغير مستوى الاخل للأسرة.

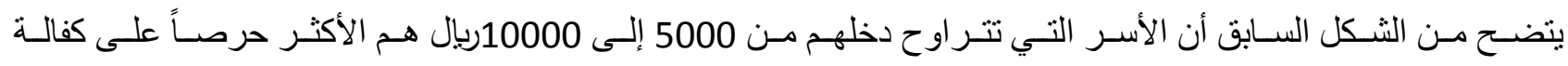

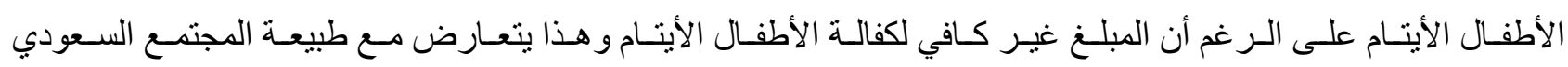

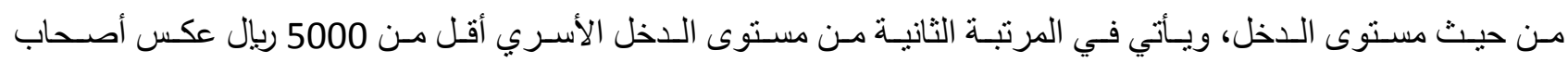
الاخل المرتفع 15000 هم الأقل في كفالة الأطفال الأيتام. نتائج الار استة وتثسير ها:

نتائج السؤال الأول ومناقشتها وتفسيرها: ما مستوى التوافق النفسي والاجتماعي لاى الأيتام ذوي الظروف الخاصة من

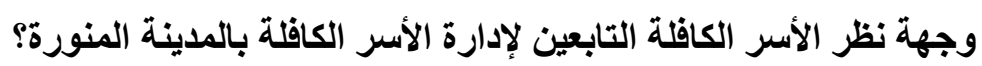

للإجابة عن السؤال السابق قام الباحث بحساب المتوسطات الحسابية و الانحر اف المعياري لإجابات أفر اد عينة الدراسة نحو

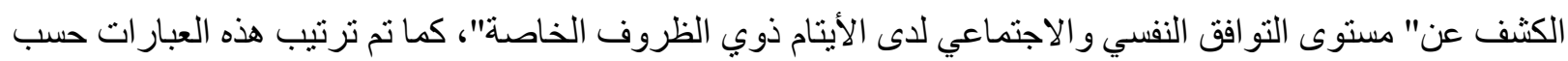
المنوسط الحسابي لكلٍ منها، وذللك كما يلي: جدول (11) التكرارات والنسب المئوية والمتوسطات الحسابية والاتحراف المعياري لإجابات عينة الدراسة على: مستوى التوافق النفسي لاى الأيتام ذوي الظروف الخاصة من وجهة نظر الأسر الكافلة ن=99

\begin{tabular}{|c|c|c|c|c|c|c|c|c|c|c|c|}
\hline \multicolumn{9}{|c|}{ درجة المو افقة و المتوسطات و الانحر افات و الترتيب } & ك & \multirow[b]{2}{*}{ 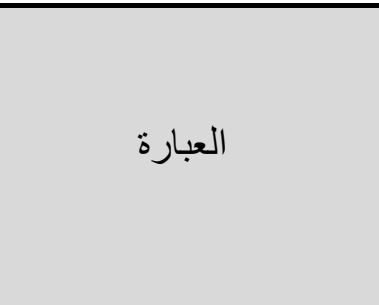 } & \multirow[b]{2}{*}{ r } \\
\hline$\frac{3}{\frac{1}{3}}$ & :7: & $\frac{\overline{7}}{\overline{7}} \overline{3}$ & $\bar{s} \overline{3}$ & 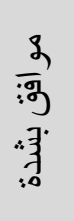 & $\frac{3}{: 3}$ & 先: & $\begin{array}{l}\text { 先; } \\
\frac{3}{3} \\
\text { :3 }\end{array}$ & 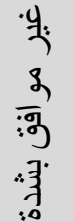 & $\&$ & & \\
\hline 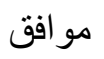 & \multirow{2}{*}{3} & \multirow{2}{*}{1.312} & \multirow{2}{*}{4.161} & 42 & 38 & 15 & 1 & 3 & ك & \multirow{2}{*}{ الأخرين مع مر اعاة شعور } & \multirow{2}{*}{1} \\
\hline بشدة & & & & 35 & 31.7 & 12.5 & 0.8 & 2.5 & $\%$ & & \\
\hline
\end{tabular}


المجلة الدولية لنشر البحوث والدراسات

International Journal of Research and Studies Publishing

ISSN: 2709-7064
المحلد الثالث - الإصدار الثامن والعشرون تأريخ الإصدار: 20 فبراير 2022 م

\begin{tabular}{|c|c|c|c|c|c|c|c|c|c|c|c|}
\hline & & & & & & & & & & الأخرين & \\
\hline \multirow{2}{*}{ 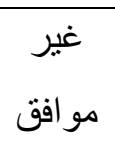 } & \multirow{2}{*}{11} & \multirow{2}{*}{0.825} & \multirow{2}{*}{2.599} & 11 & 20 & 13 & 28 & 27 & ك5 & \multirow{2}{*}{ لا يتكيف داخل المنزل } & \multirow{2}{*}{2} \\
\hline & & & & 9.2 & 16.7 & 10.8 & 23.3 & 22.5 & $\%$ & & \\
\hline \multirow{2}{*}{ 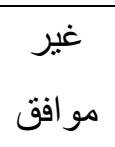 } & \multirow{2}{*}{12} & \multirow{2}{*}{1.269} & \multirow{2}{*}{2.505} & 10 & 17 & 11 & 36 & 25 & 5 & \multirow{2}{*}{ تناول الطعام لفتر ات طعدم الرغبة في } & \multirow{2}{*}{3} \\
\hline & & & & 8.3 & 14.2 & 9.2 & 30 & 20.8 & $\%$ & & \\
\hline \multirow{2}{*}{ أو افق } & \multirow{2}{*}{13} & \multirow{2}{*}{1.353} & \multirow{2}{*}{2.474} & 25 & 50 & 14 & 8 & 2 & ك5 & \multirow{2}{*}{ يميل إلى الانطو ائية و البعد } & \multirow{2}{*}{4} \\
\hline & & & & 20.8 & 41.7 & 11.7 & 6.7 & 1.7 & $\%$ & & \\
\hline \multirow{2}{*}{ أو اقق } & \multirow{2}{*}{5} & \multirow{2}{*}{0.946} & \multirow{2}{*}{3.888} & 25 & 50 & 14 & 8 & 2 & ك5 & \multirow{2}{*}{ القدرة على فهم مشاعر } & \multirow{2}{*}{5} \\
\hline & & & & 20.8 & 41.7 & 11.7 & 6.7 & 1.7 & $\%$ & & \\
\hline \multirow{2}{*}{ 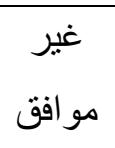 } & \multirow{2}{*}{10} & \multirow{2}{*}{0.783} & \multirow{2}{*}{2.818} & 13 & 23 & 12 & 35 & 16 & 5) & \multirow{2}{*}{ تصدر أساليب عدو انية عند } & \multirow{2}{*}{6} \\
\hline & & & & 10.8 & 19.2 & 10 & 29.2 & 13.3 & $\%$ & & \\
\hline غير غ & 0 & 1200 & 2010 & 12 & 28 & 14 & 30 & 15 & ك5 & يبدو عليه في بعض & 7 \\
\hline مو افق & J & טכנ.1 & 2.517 & 10 & 23.3 & 11.7 & 25 & 12.5 & $\%$ & المو اقف فئة الثقة بالنفس & 7 \\
\hline 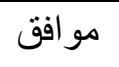 & 2 & 1260 & רח 1 & 56 & 24 & 13 & 4 & 2 & 5 & ثقته كبيره بأفر اد الأسرة. & \\
\hline 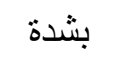 & 2 & כטك. & 4.252 & 46.7 & 20 & 10.8 & 3.3 & 1.7 & $\%$ & & 0 \\
\hline مالفت & 6 & 1210 & & 24 & 35 & 9 & 17 & 14 & 5) & يحتاج للمزيد من الأمن & \\
\hline مو اتق & 0 & 1.319 & 3.383 & 20 & 29.2 & 7.5 & 14.2 & 11.7 & $\%$ & النفسي داخل الأسرة & J \\
\hline & & & & 57 & 29 & 12 & 0 & 1 & ك5 & يشعر بالدفء و الحماية & \\
\hline & 1 & 0.933 & 4.424 & 47.5 & 24.2 & 10 & 0 & 0.8 & $\%$ & و والانتماء معنا & 10 \\
\hline & & & & 36 & 47 & 12 & 3 & 1 & 5 & يصدر مشاعر مقبولة ناحية & \\
\hline مو الق & 4 & 1.500 & 4.1J2 & 30 & 39.2 & 10 & 2.5 & 0.8 & $\%$ & إخو انه داخل المنزل & $1 \perp$ \\
\hline 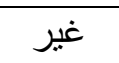 & & & & 8 & 13 & 20 & 28 & 30 & ك5 & لايه احساس بالشعور & \\
\hline مو افق & 14 & 1.252 & 2.404 & 6.7 & 10.8 & 16.7 & 23.3 & 25 & $\%$ & بالتهديد المستمر & 12 \\
\hline 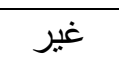 & & & & 6 & 21 & 8 & 23 & 41 & 5) & يحس بالنبذ و عدم رغبة & \\
\hline مبثدة & 15 & 1.232 & 2.272 & 5 & 17.5 & 6.7 & 19.2 & 34.2 & $\%$ & الأخرين به & 13 \\
\hline مو افق & 8 & 0.982 & 3.232 & 13 & 41 & 12 & 22 & 11 & ك5 & يحتاج إلى المزيد من & 14 \\
\hline
\end{tabular}




\begin{tabular}{|c|c|c|c|c|c|c|c|c|c|c|c|}
\hline & & & & 10.8 & 34.2 & 10 & 18.3 & 9.2 & $\%$ & الشعور بذاته & \\
\hline \multirow[t]{2}{*}{ موافق } & \multirow[b]{2}{*}{7} & \multirow[b]{2}{*}{1.298} & \multirow[b]{2}{*}{3.363} & 18 & 35 & 21 & 15 & 10 & ك5 & \multirow{2}{*}{ جماعة تربطه بهم بأنه عضو فيل مشالح } & \multirow[b]{2}{*}{15} \\
\hline & & & & 15 & 29.2 & 17.5 & 12.5 & 8.3 & $\%$ & & \\
\hline \multicolumn{3}{|c|}{7.544} & 48.090 & & & & & & & الارجة الكلية & \\
\hline
\end{tabular}

يتضح من الجدول (11) ما يلي:

-جاءت العبارة رقم (10) في استنيان مشكلات التو افق النفسي للأطفال الأيتام ذوي الظروف الخاصـة: في المرنبـة الأولى ومحتو اهـا (يثـعر بالدفه و الحمايـة و الانتمـاء معنـا) بمتوسط حسـابي (4.424)درجـة، و انحر اف معيـاري (0.933)، حيث وقعت في الفئة الخامسة من المقياس الخماسي و التي تتر اوح ما بين 4.20 إلى أقل من 5.00؛ بدرجة مو افق بشدة. - جاءت العبارة رقم (8) من وجهة نظر عينة الدر اسة في المرتبة الثانية ومحتو اها (ثقته كبيره بأفراد الأسرة) بمتوسط حسابي (4.292) درجة، و انحر اف معياري (1.369)، حيث وقعت في الفئة الخامسة من المقياس الخماسي و التي تتر اوح مـا بين 4.20 إلى أقل من 5.00، بدرجة مو افق بثدة. - جاءت العبارة رقم (1) من وجهة نظر عينة الدر اسة في المرنبة الثالثة ومحتو اها (ويتمتع بالثقة في النفس مـع الأخرين مـع مر اعاة شعور الأخرين) بمنوسط حسـابي (4.161) درجة، وانحر اف معياري (1.312)، حيث وقعت في الفئة الرابعة من المقياس الخماسي و التي تتر اوح ما بين 3.40 إلى أقل من 4.20، بدرجة مو افق. - جاءت العبارة رقم (11) من وجهة نظر عينة الدراسـة في المرتبـة الرابعة ومحتو اهـا (يصدر مشـاعر مقبولنة ناحية إخوانه داخل المنزل) بمتوسط حسـي (4.152) درجـة، وانحر اف معيـاري (1.380)، حيث وقعت في الفئة الرابعة من المقيساس الخماسي و التي تتر اوح ما بين 3.40 إلى أقل من 4.20، بدرجة مو افق بشدة. - جـاءت العبارة رقم (5) من وجهة نظر عينة الدر اسـة في المرتبـة الخامسـة ومحتو اهـا (القدرة على فهم مشـاعر الآخرين تجاهه) بمنوسط حسابي (3.888) درجة، و انحر اف معياري (0.946)، حيث وقعت في الفئة الر ابعة من المقياس الخماسي و التي تتر اوح ما بين 3.40 إلى أقل من 4.20، بدرجة مو افق بشدة. - جاءت العبارة رقم (6) من وجهة نظر عينة الدراسة في المرتبة السادسة ومحتو اهـا (يحتاج للمزيد من الأمن النفسي داخل الأسرة) بمنوسط حسابي (3.383) درجة، وانحر اف معياري (1.319)، حيث وقعت في الفئة الر ابعة من المقياس الخماسي و التي تتر اوح ما بين 3.40 إلى أقل من 4.20، بدرجة مو افق. 
- جاءت العبارة رقم (15) من وجهة نظر عينة الدراسة في المرتبـة السـابعة ومحتو اهـا (بشـعر بأنه عضو في جماعـة تربطه بهم مصـالح مشـركة) بمتوسط حسـابي (3.363) درجـة، وانحر اف معيـاري (1.298)، حيث وقعت في الفئة الر ابعـة مـن المقياس الخماسي و التي تتر اوح ما بين 3.40 إلى أقل من 4.20، بدرجة مو افق.

- جاءت العبارة رقم (14) من وجهة نظر عينة الدراسة في المرنبـة الثامنـة ومحتو اهـا (يحتاج إلى المزيد من الثـعور بذاته) بمتوسط حسابي (3.232) درجة، و انحر اف معياري (0.982)، حيث وقعت في الفئة الر ابعـة من المقياس الخماسي و التي تتر اوح ما بين 3.40 إلى أقل من 4.20، بدرجة مو افق. - جاءت العبارة رقم (7) من وجهة نظر عينة الدراسة في المرتبة التاسعة ومحتو اها (يبدو عليه في بعض المو اقف فئة الثقة بالنفس) بمنوسط حسابي (2.919) درجة، و انحر اف معياري (1.390)، حيث وقعت في الفئة الثالثة من المقياس الخماسي و التي تتر اوح ما بين 3.40 إلى أقل من 4.20، بدرجة غير متأكد. - جـاءت العبارة رقم (6) من وجهة نظر عينـة الدراسـة في المرتبـة الحاديـة عثر ومحتو اهـا (بصدر أسـاليب عدو انيـة عند تعرضـه للإيذاء) متوسط حسـي (2.818) درجـة، و انحر اف معياري (0.783)، حيث وقعت في الفئة الثالثة من المقياس الخماسي و التي تتراوح ما بين 3.40 إلى أقل من 4.20، بدرجة غير متأكد. - جاءت العبارة رقم (1) من وجهة نظر عينة الدراسـة في المرتبـة الثنانية عشر ومحتو اهـا (تقديم الخدمات الانتقالية للطلاب ذوي صعوبات التعلم من خلال فريق متخصص) منوسط حسابي (1.565) درجة، و انحر اف معياري (0.688)، حيث وقعت في الفئة الأولى من المقياس الثناثي والتي تتر اوح ما بين 1 إلى أقل من 1,80، بدرجة غير موافق بشدة.

- جـاءت العبارة رقم (2) من وجهة نظر عينة الدر اسـة في المرتبـة الثالثة عشر ومحتو اهـا (لا يتكيف داخل المنزل بشكل مستمر ) متوسط حسابي (2.599) درجـة، و انحر اف معياري (0.825)، حيث وقعت في الفئة الثالثة من المقباس الخماسي و التي تتر اوح ما بين 2.60 إلى أقل من 3.40، بدرجة غير متأكد. - جاءت العبارة رقم (3) من وجهة نظر عينـة الدر اسـة في المرتبـة الرابعة عثر ومحتو اهـا (يثـعر بعدم الرغبة في تنـاول الطعـام لفتر ات طويلـة) متوسط حسـبي (2.505) درجـة، و انحر اف معيـاري (1.269)، حيث وقعـت في الفئسة الثانيـة مـن المقياس الخماسي و التي تتر اوح ما بين 2.60 إلى أقل من 3.40؛ بدرجة غير منأكد. - جاءت العبارة رقم (4) من وجهة نظر عينة الدراسة في المرتبة الخامسة عشر ومحتو اهـا (يميل إلى الانطو ائية و البعد عن الأخرين) متوسط حسابي (2.474) درجة، و انحر اف معياري (1.353)، حيث وقعت في الفئة الثانية من المقياس الخماسي و التي تتر اوح ما بين 2.60 إلى أقل من 3.40، بدرجة غير متأكد. 
- جاءت العبارة رقم (12) من وجهة نظر عينة الدر اسة في المرتبة الخامسة عشر ومحتو اهـا (لديه احسـاس بالثعور بالتهديد المستمر ) متوسط حسابي (2.404) درجة، و انحر اف معياري (1.252)، حيث وقعت في الفئة الثانيـة من المقياس الخماسي و التي تتر اوح ما بين 1.80 إلى أقل من 2.60، بدرجة غير منو افق.

- جـاءت العبارة رقم (13) من وجهة نظر عينـة الدر اسـة في المرتبـة الخامسـة عثـر ومحتو اهـا (يحس بالنبذ و عدم رغبـة الأخرين به) متوسط حسابي (2.272) درجة، و انحر اف معياري (1.232)، حيث وقعت في الفئة الثانبة من المقياس الخماسي والتي تتراوح ما بين 2.60 إلى أقل من 3.40، بدرجة غير متأكد.

ويمكن استشهاد نتائج الدر اسة من خلال أدبيات الدر اسة و الدر اسات السابقة، حيث نجد أن على سبيل المثال المعوقات الجسمية للدى الأطفال تكون عائقاً وتوجد من المشكلات النفسية لدى الاسـر الكافلة من خـلال معانـاتهم في فترة التربيـة أو كفالتهم للأطفال، كذلك من المعوقات الاجتماعبة نقص الصداقة وعدم قدرة الأطفال على كسب الأصدقاء في مواجهة السخرية أو

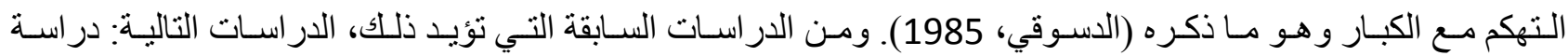
العمور (2015) حيث هدفت الدر اسة إلى المشكلات الانفعالية و الاجتماعية لاى الأيتام المر اهقين وتوصلت الدراسة إلى وجود فروق دالة احصائيا في مدى انتشار المشكلات الانفعالية والاجتماعية باختلاف الجنس ولصالح الذكور. جدول (12) التكرارات والنسب المئوية والمتوسطات الحسابية والانحراف المعياري لإجابات عينة الدراسة على: مستوى التوافق الاجتماعي لاى الأيتام ذوي الظروف الخاصة من وجهة نظر الأسر الكافلة ن=99

\begin{tabular}{|c|c|c|c|c|c|c|c|c|c|c|c|}
\hline \multicolumn{9}{|c|}{ درجة المو افقة و المتوسطات و الانحر افات و الترتبب } & 5 & \multirow[b]{2}{*}{ 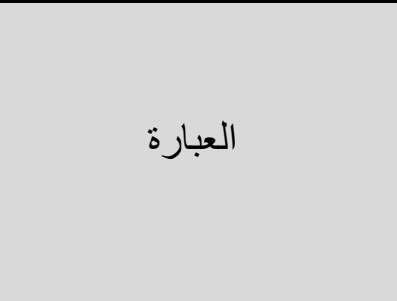 } & \multirow[b]{2}{*}{ s } \\
\hline$\frac{3}{\frac{1}{3}}$ & 司: & $\begin{array}{ll}\bar{x} & \overline{3} \\
\bar{y} & \bar{y}:\end{array}$ & $\overline{7} \frac{7}{3}$ & 高 & $\frac{3}{3}$ & 势 & $\frac{4}{3}$ & 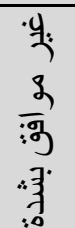 & $\begin{array}{l}\& \\
\%\end{array}$ & & \\
\hline \multirow{2}{*}{ 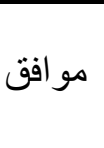 } & \multirow{2}{*}{7} & \multirow{2}{*}{1.124} & \multirow{2}{*}{3.414} & 17 & 37 & 18 & 24 & 3 & ك & \multirow{2}{*}{ يشبع احتياجاته دون أن } & \multirow{2}{*}{1} \\
\hline & & & & 14.2 & 30.8 & 15 & 20 & 2.5 & $\%$ & & \\
\hline \multirow{2}{*}{ بثير } & \multirow[b]{2}{*}{10} & \multirow[b]{2}{*}{1.429} & \multirow[b]{2}{*}{2.565} & 14 & 16 & 12 & 27 & 30 & ك & \multirow{2}{*}{ يخيل إلى الانسحاب عندما } & \multirow[b]{2}{*}{2} \\
\hline & & & & 11.7 & 13.3 & 10 & 22.5 & 25 & $\%$ & & \\
\hline \multirow{2}{*}{ 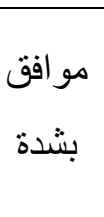 } & \multirow[b]{2}{*}{4} & \multirow[b]{2}{*}{1.170} & \multirow[b]{2}{*}{3.909} & 40 & 28 & 18 & 8 & 5 & ك & \multirow{2}{*}{$\begin{array}{c}\text { يكون صداقات تفاعلية مع الآخرين ويخلق جواً من } \\
\text { المرح. }\end{array}$} & \multirow[b]{2}{*}{3} \\
\hline & & & & 33.3 & 23.3 & 15 & 6.7 & 4.2 & $\%$ & & \\
\hline \multirow{2}{*}{ مو افق } & \multirow{2}{*}{6} & \multirow{2}{*}{1.100} & \multirow{2}{*}{3.494} & 15 & 48 & 10 & 23 & 3 & ك & \multirow{2}{*}{ يشعر بجو من التفاهم خارج } & \multirow{2}{*}{4} \\
\hline & & & & 12.5 & 40 & 8.3 & 19.2 & 2.5 & $\%$ & & \\
\hline
\end{tabular}


المجلة الدولية لنشر البحوث والدراسات

International Journal of Research and Studies Publishing

ISSN: 2709-7064
المجلد الثالث - الإصدار الثامن والعشرون تأريخ الإصدار: 20 فبراير 2022 م

\begin{tabular}{|c|c|c|c|c|c|c|c|c|c|c|c|}
\hline \multirow[b]{2}{*}{ مو افق ل } & \multirow[b]{2}{*}{5} & \multirow[b]{2}{*}{1.010} & \multirow[b]{2}{*}{3.858} & 29 & 40 & 19 & 9 & 2 & ك5 & \multirow{2}{*}{ يمتلأك قدرة عالية على فهم } & \multirow[b]{2}{*}{5} \\
\hline & & & & 24.2 & 33.3 & 15.8 & 7.5 & 1.7 & $\%$ & & \\
\hline \multirow[b]{2}{*}{ مو افق } & \multirow[b]{2}{*}{3} & \multirow[b]{2}{*}{0.896} & \multirow[b]{2}{*}{4.050} & 34 & 44 & 13 & 8 & 0 & 5 & \multirow{2}{*}{ ينجذب إلى المشاركة مع الأه من الأبناء في } & \multirow[b]{2}{*}{6} \\
\hline & & & & 28.3 & 36.7 & 10.8 & 6.7 & 0 & $\%$ & & \\
\hline \multirow{2}{*}{ مو افق } & \multirow{2}{*}{2} & \multirow{2}{*}{0.899} & \multirow{2}{*}{4.080} & 36 & 43 & 12 & 8 & 0 & ك & \multirow{2}{*}{ متكيف داخل المنزل و لا } & \multirow{2}{*}{7} \\
\hline & & & & 30 & 35.8 & 10 & 6.7 & 0 & $\%$ & & \\
\hline \multirow{2}{*}{ مو افق ل } & \multirow{2}{*}{1} & \multirow{2}{*}{0.760} & \multirow{2}{*}{4.252} & 40 & 48 & 7 & 4 & 0 & ك & \multirow{2}{*}{ يتميز باكتساب مهار ات من } & \multirow{2}{*}{8} \\
\hline & & & & 33.3 & 40 & 5.8 & 3.3 & 0 & $\%$ & & \\
\hline \multirow{2}{*}{ غو افق } & \multirow{2}{*}{9} & \multirow{2}{*}{1.171} & \multirow{2}{*}{2.299} & 7 & 33 & 15 & 34 & 10 & ك & \multirow{2}{*}{ بصعب عليه الاستقلالية في } & \multirow{2}{*}{9} \\
\hline & & & & 5.8 & 27.5 & 12.5 & 28.3 & 8.3 & $\%$ & & \\
\hline \multirow{2}{*}{ 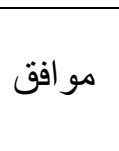 } & \multirow{2}{*}{ 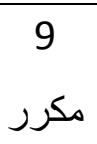 } & 1260 & חמת ? & 13 & 30 & 12 & 25 & 19 & ك & يحتاج إلى المزيد من الأمن & 10 \\
\hline & & דים & 2.800 & 10.8 & 25 & 10 & 20.8 & 15.8 & $\%$ & الاجتماعي داخل المنزل & \\
\hline 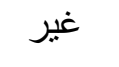 & & & & 5 & 10 & 18 & 32 & 34 & ك & الكذر & \\
\hline 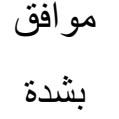 & 12 & 1.166 & 2.191 & 4.2 & 8.3 & 15 & 26.7 & 28.3 & $\%$ & جميع أقو اله & 11 \\
\hline غير & & & & 6 & 3 & 11 & 30 & 49 & ك & & \\
\hline 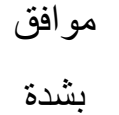 & 13 & 1.124 & 1.858 & 5 & 2.5 & 9.2 & 25 & 40.8 & $\%$ & & 12 \\
\hline غير & 111 & 1186 & 2411 & 5 & 18 & 14 & 38 & 24 & ك5 & يظهر عليه العناد و التمرد & 12 \\
\hline مو افق & & & & 4.2 & 15 & 11.7 & 31.7 & 20 & $\%$ & عندما يطلب منه شيء & \\
\hline & 8 & 120 & חרת & 12 & 38 & 13 & 17 & 19 & ك] & ييكي الطفل عندما يعلو & 1 \\
\hline 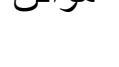 & مكرر - & נדט.1 & ש & 10 & 31.7 & 10.8 & 14.2 & 15.8 & $\%$ & الصوت في وجها & \\
\hline & 00 & 1201 & חרת ב & 21 & 21 & 16 & 26 & 15 & ك] & يميل في التفاعل للإناث & 15 \\
\hline a & 00 & דבנ.1 & . & 17.5 & 17.5 & 13.3 & 21.7 & 12.5 & $\%$ & أكثر من الذكور & J \\
\hline & 3.983 & & 48.88 & & & & & & & الارجة الكلية & \\
\hline
\end{tabular}

يتضح من الجدول (12) ما يلي: 
- جاءت العبارة رقم (8) في استبيان مشكلات التو افق الاجتماعي للأطفال الأيتام ذوي الظروف الخاصـة: في المرتبـة الأولى ومحتو اها (يتميز باكتساب مهار ات من أقر انه) بمتوسط حسـي (4.252)درجة، و انحر اف معياري (2.929)، حيث وقعت في الفئة الخامسة من المقياس الخماسي و التي تتر اوح ما بين 4.20 إلى أقل من 5.0، بدرجة مو افق بشدة.

- جاءت العبارة رقم (7) من وجهة نظر عينة الدر اسة في المرتبـة الثانيـة ومحتو اهـا (متكيف داخل المنزل و لا يقوم بأسـاليب عدو انية) بمنوسط حسابي (4.080) درجة، و انحر اف معياري (1.369)، حيث وقعت في الفئة الخامسة من المقياس الخماسي و التي تتر اوح ما بين 4.20 إلى أقل من 5.0، بدرجة مو افق بشدة.

- جاءت العبارة رقم (6) من وجهة نظر عينة الدر اسـة في المرتبـة الثالثة ومحتو اهـا (ينجذب إلى المشـاركة هـع إخو انهه من الأبناء في الأعمال المنزلية) بمتوسط حسابي (4.050) درجة، وانحر اف معياري (0.896)، حيث وقعت في الفئة الخامسـة من المقياس الخماسي و التي نتراوح ما بين 4.20 إلى أقل من 5.0، بدرجة مو افق بثدة.

- جاءت العبارة رقم (3) من وجهة نظر عينة الدر اسة في المرتبـة الر ابعة ومحتو اها (يكون صداقات تفاعلية مع الآخرين ويخلق جو اً مـن المـرح) بمنوسط حسـي (3.909) درجـة، وانحر اف معياري (1.170)، حيث وقعت في الفئة الرابعـة مـن المقيـاس الخماسي والتي تتر اوح ما بين 3.40 إلى أقل من 4.20، بدرجة مو افق.

- جاءت العبارة رقم (5) من وجهة نظر عينة الدر اسة في المرتبة الخامسة ومحتو اهـا (يمتلك قدرة عالية على فهم الأخرين داخل المنزل وخارجـه) بمنوسط حسـي (3.858) درجة، و انحر اف معياري (1.010)، حيث وقعت في الفئة الر ابعـة من المقياس الخماسي و التي تتر اوح ما بين 3.40 إلى أقل من 4.20، بدرجة مو افق.

- جـاءت العبارة رقم (4) من وجهة نظر عينة الدر اسـة في المرنبـة السادسة ومحتو اهـا (يثـعر بجو من التفاهم خـار ج المنزل) بمتوسط حسـبي (3.494) درجـة، و انحر اف معياري (1.100)، حيث وقعت في الفئة الر ابعـة مـن المقيساس الخماسـي والتي تتر اوح ما بين 3.40 إلى أقل من 4.20، بدرجة.

- جاءت العبارة رقم (1) من وجهة نظر عينـة الدراسـة في المرتبة السابعة ومحتو اهـا (يشبع احتياجاته دون أن يطلبها) بمتوسط حسابي (3.414) درجة، و انحر اف معياري (1.124)، حيث وقعت في الفئة الرابعة من المقياس الخماسي و التي تتر اوح مـا بين 3.40 إلى أقل من 4.20، بدرجة أو افق.

- جاءت العبارة رقم (15) من وجهة نظر عينة الدر اسة في المرتبـة الثامنـة ومحتو اهـا (يميل في التفاعل للإنـاث أكثر من الذكور ) بمتوسط حسابي (3.070) درجة، و انحر اف معياري (1.394)، حيث وقعت في الفئة الثالثة من المقياس الخماسي و التي تتر اوح ما بين 2.60 إلى أقل من 3.40، بدرجة غير متأكد. 
- جاءت العبارة رقم (14) من وجهة نظر عينـة الدراسـة في المرتبـة التاسعةة ومحتو اهـا (يبكي الطفل عندما يعلو الصـوت في وجهه) بمتو سط حسابي (3.070) درجة، و انحر اف معياري (1.349)، حيث وقعت في الفئة الثالثة من المقياس الخماسي و التي تتر اوح ما بين 2.60 إلى أقل من 3.40؛ بدرجة غير متأكد. - جاءت العبارة رقم (9) من وجهة نظر عينة الدراسة في المرتبة الحاديـة عشر ومحتو اهـا (يصعب عليه الاستقلالية في أر ائه مـع الآخرين) متوسط حسـي (2.299) درجـة، وانحر اف معياري (1.171)، حيث وقعت في الفئة الثالثة من المقياس الخماسي والتي تتر اوح ما بين 2.60 إلى أقل من 3.40، بدرجة غير متأكد.

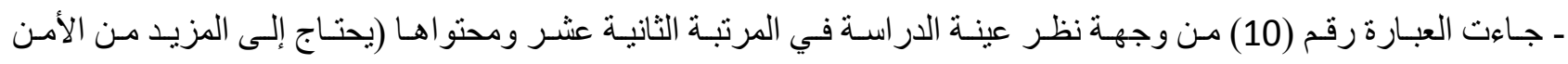

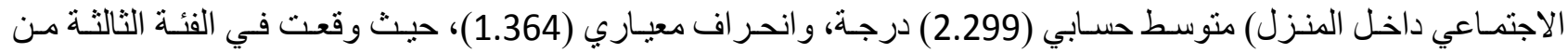
المقياس الخماسي و التي تتر اوح ما بين 2.60 إلى أقل من 3.40؛ بدرجة غير متأكد. - جاءت العبارة رقم (2) من وجهة نظر عينة الدراسـة في المرتبـة الثالثة عثر ومحتو اهـا (يميل إلى الانسحاب عندما يخرج مـع اخو انـه في الحدائق العامـة) منوسط حسـابي (2.565) درجـة، وانحر اف معيـاري (1.429)، حيث وقعت في الفئة الثالثة مـن المقياس الخماسي و التي تتر اوح ما بين 2.60 إلى أقل من 3.40؛ بدرجة غير متأكد.

- جاءت العبارة رقم (13) من وجهة نظر عينـة الدراسـة في المرتبـة الرابعة عشر ومحتو اهـا (يظهر عليه العنـاد والتمرد عندما يطلب منـه شـيء) متوسط حسـابي (2.414) درجـة، و انحر اف معيـاري (186)، حيث وقعت في الفئة الثالثـة مـن المقيـاس الخماسي و التي تتراوح ما بين 2.60 إلى أقل من 3.40، بدرجة غير متأكد.

- جـاءت العبـارة رقم (11) من وجهة نظر عينـة الدراسـة في المرتبـة الخامسـة عشر ومحتو اهـا (الكذب سمة أساسية في جميع أقو اله) متوسط حسابي (2.191) درجة، و انحر اف معياري (1.166)، حيث وقعت في الفئة الثالثة من المقياس الخماسي و التي تتراوح ما بين 2.60 إلى أقل من 3.40، بدرجة غير متأكد.

- جاءت العبارة رقم (12) من وجهة نظر عينة الدراسـة في المرتبـة الخامسة عشر ومحتو اهـا (يقوم الطفل بسرقة زملائه داخل الفصـل الدر اسـي) متوسط حسـي (1.858) درجـة، و انحر اف معيـاري (1.124)، حيث وقعت في الفئة الثانيـة مـن المقيـاس الخماسي والتي تتراوح ما بين 1.80 إلى أقل من 2.60، بدرجة غير مو افق.

ويؤكد العبار ات كما جاء في در اسة العطار (2019) أن أكثر المشكلات هي المشكلات السلوكية انتشـار اً لدى الأطفال الأيتام حيث توصلت الدراسة إلى إظهار عدم وجود فروق دالة احصـائية بين الذكور و الإنـاث في المشكلات السلوكية ولم تظهر فروق في متغير الحرمان، وفي دراسة العتيبي (2021) هدفت إلى التعرف على مدى فاعلية برنـامج إرشـادي انتقائي لتنمية النت افق النفسي و الإجتماعي لدى الايتام ونوصلت الدراسة إلى تنمية التو افق النفسي و الاجتماعي حيث وجدت فروق ذات دلالة

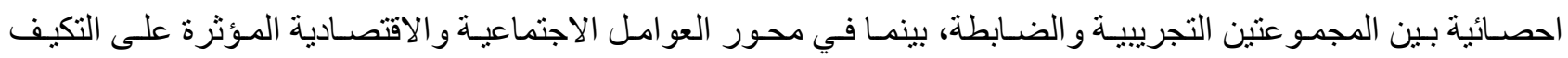


أظهرت در اسـة القديري(2019) الكثـف عن أثر العو امل الاجتماعيـة والاقتصـادية على التكيف الاجتمـاعي لأسـر الأيتـام و اعتمدت الدر اسـة على العينـة العشـوائية وتوصلت الدر اسـة إلى أن بعض العو امل الاجتماعيـة وخاصـة عمر الأم و الحالـة الاجتماعية لها لبس له علاقة بمعدل التكيف الاجتماعي. 1-1 نتائج السؤال الثاني ومناقثتها وتفسيرها: هل يختلف مستوى التوافق النفسي والاجتمـاعي للأيتام ذوي الظروف الخاصة من وجهة نظر الأسر الكافلة لهم تعزي للنوع (ذكور- إناث)؟

لمعرفة ما إذا كانت هنالك فروق ذات دلالة إحصائية بين وجهات نظر عينة الدر اسة في تحديد مستوى التو افق النفسي و الاجتماعي للأيتام ذوي الظروف الخاصة تبعًا لاختلاف متغير الجنس. تم استخدام اختبار (ت) (T-Test)، كما ينضح في

$$
\text { الجدولين التاليين رقم (4)، (5): }
$$

جدول (13) نتائج اختبار ت (T-Test) للفروق بين متوسطات استجابات أفراد عينة الاراسة نحو مستوى التوافق النفسي

$$
\text { للأيتام تعزي لمتغير الجنس ن=99 }
$$

\begin{tabular}{|c|c|c|c|c|c|c|c|}
\hline \multicolumn{2}{|c|}{ مستوى الدلالة } & قيمة & الالمر اف المياري & المستوسط & العدد & الجنس & محور \\
\hline \multirow{2}{*}{ 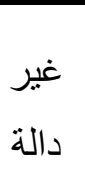 } & \multirow[b]{2}{*}{0.258} & \multirow[t]{2}{*}{0.214} & 0.795 & 4.352 & 51 & أنثى & \multirow{2}{*}{ يتمتع بالثقة في النفس مع الأخرين مع } \\
\hline & & & 1.30 & 3.958 & 48 & ذكر & \\
\hline \multirow{2}{*}{ 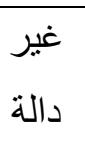 } & \multirow{2}{*}{0.978} & \multirow[t]{2}{*}{0.136} & 1.374 & 2.431 & 51 & أنثى & \multirow[t]{2}{*}{ لا يتكيف داخل المنزل بشكل مستمر. } \\
\hline & & & 1.354 & 2.770 & 48 & ذكر & \\
\hline \multirow[b]{2}{*}{ 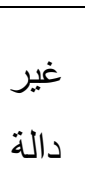 } & \multirow[b]{2}{*}{0.915} & \multirow[t]{2}{*}{1.191} & 1339 & 2.352 & 51 & أنثى & \multirow{2}{*}{ يشعر بعدم الرغبة في تناول الطعام } \\
\hline & & & 1.277 & 2.666 & 48 & ذكر & \\
\hline \multirow{2}{*}{ 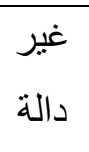 } & \multirow{2}{*}{0.229} & \multirow[t]{2}{*}{2.263} & 1.337 & 2.176 & 51 & أنثى & \multirow[t]{2}{*}{ يميل إلى الانطو ائية و البعد عن الأخرين. } \\
\hline & & & 1.369 & 2.291 & 48 & ذكر & \\
\hline \multirow{2}{*}{ 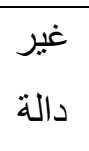 } & \multirow{2}{*}{0.799} & \multirow[t]{2}{*}{0.282} & 0.938 & 3.862 & 51 & أنثى & \multirow[t]{2}{*}{ القرة على فهم مشاعر الأخرين تجاهه. } \\
\hline & & & 0.963 & 3.916 & 48 & ذكر & \\
\hline \multirow{2}{*}{ 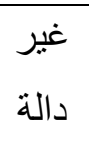 } & \multirow{2}{*}{0.255} & \multirow[t]{2}{*}{3.495} & 2.217 & 2.392 & 51 & أنثى & \multirow{2}{*}{ يصدر أساليب عدو انية عند تعرضه } \\
\hline & & & 1.283 & 3.270 & 48 & ذكر & \\
\hline \multirow{2}{*}{ 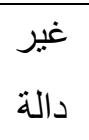 } & \multirow{2}{*}{0.742} & \multirow[t]{2}{*}{1.066} & 1.300 & 2.784 & 51 & أنثى & \multirow{2}{*}{ يبدو عليه في بعض المو اقف قلة الثقة } \\
\hline & & & 1.294 & 3.062 & 48 & ذكر & \\
\hline
\end{tabular}




\begin{tabular}{|c|c|c|c|c|c|c|c|}
\hline \multicolumn{2}{|c|}{ 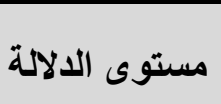 } & قيمة & الانحر اف & المتوسط & العدد & الجنس & محور \\
\hline \multirow{2}{*}{ غير } & \multirow{2}{*}{0.971} & \multirow[t]{2}{*}{0.830} & 1.019 & 4.372 & 51 & أنثى & \multirow{2}{*}{ تقته كبيرة بأفر اد الأسرة. } \\
\hline & & & 0.944 & 4.208 & 48 & ذكر & \\
\hline \multirow{2}{*}{ 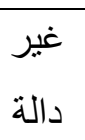 } & \multirow{2}{*}{0.148} & \multirow[t]{2}{*}{2.778} & 1.378 & 3.019 & 51 & أنثى & \multirow{2}{*}{ يحتاج للمزيد من الأمن النفسي داخل } \\
\hline & & & 1.308 & 3.770 & 48 & ذكر & \\
\hline \multirow{2}{*}{ 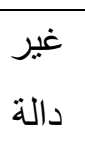 } & \multirow{2}{*}{0.128} & \multirow[t]{2}{*}{1.121} & 1.378 & 4.509 & 51 & أنثى & \multirow[t]{2}{*}{ يشعر بالدفء و الحماية و الانتماء معنا. } \\
\hline & & & 1.308 & 4.333 & 48 & ذكر & \\
\hline \multirow{2}{*}{ 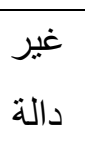 } & \multirow{2}{*}{0.834} & \multirow[t]{2}{*}{0.066} & 0.880 & 4.156 & 51 & أنثى & \multirow{2}{*}{ يصدر مشاعر مقبولة ناحية إخوانه داخل } \\
\hline & & & 0.771 & 4.145 & 48 & ذكر & \\
\hline \multirow{2}{*}{ غير } & \multirow{2}{*}{0.565} & \multirow[t]{2}{*}{0.96} & 1.266 & 2.392 & 51 & أنثى & \multirow[t]{2}{*}{ لديه إحساس بالثعور بالتهديد المستمر . } \\
\hline & & & 1.285 & 2.416 & 48 & ذكر & \\
\hline \multirow{2}{*}{ غير } & \multirow{2}{*}{0.317} & \multirow[t]{2}{*}{1.643} & 1.3347 & 2.058 & 51 & أنثى & \multirow[t]{2}{*}{ يحس بالنبذ وعدم رغبة الآخرين به. } \\
\hline & & & 1.336 & 2.500 & 48 & ذكر & \\
\hline \multirow{2}{*}{ دالة } & \multirow{2}{*}{0.747} & \multirow[t]{2}{*}{0.616} & 1.270 & 3.156 & 51 & أنثى & \multirow[t]{2}{*}{ يحتاج إلى المزيد من الشعور بذاته. } \\
\hline & & & 1.240 & 3.312 & 48 & ذكر & \\
\hline \multirow{2}{*}{ 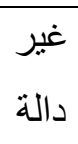 } & \multirow{2}{*}{0.758} & \multirow[t]{2}{*}{0399} & 1.251 & 3.411 & 51 & أنثى & \multirow{2}{*}{ يشُعر بأنه عضو في جماعة تربطه بهم } \\
\hline & & & 1.223 & 3.312 & 48 & ذكر & \\
\hline \multirow{2}{*}{ غير } & \multirow{2}{*}{0.575} & \multirow[t]{2}{*}{2.069} & 7.957 & 49.588 & 51 & أنثى & \\
\hline & & & 6.782 & 46.500 & 48 & ذكر & \\
\hline
\end{tabular}

يتضح من الجدول (13) يظهر في عبار ات المحور الأول (مشكلات التو افق النفسي عدم وجود فروق ذات دلالة احصائية بين عبار ات المحور والدرجة الكلية من حيث متغير الذكور و الإناث، وتظهر كالتالي:

لا يوجد فروق دالـة احصـائية بين الفقرة رقم (1) ومحتو اهـا " يتمتع بالثقة في النفس مـع الأخرين مـع مر اعـاة شـعور الأخرين." بين الذكور و الإناث من الأسر الكافلة في استجاباتهم لهذه العبارة. لا يوجد فروق دالة احصائية بين الفقرة رقم (2) و محتو اها " لا يتكيف داخل المنزل بشكل مستمر" بين الذكور و الإنـاث من الأسر الكافلة في استجاباتهم لهذه العبارة. لا يوجد فروق دالة احصائية بين الفقرة رقم (3) ومحتو اها " يشعر بعدم الرغبة في تنـاول الطعام لفتر ات طويلـة." بين الذكور و الإناث من الأسر الكافلة في استجاباتهم لهذه العبارة. 
لا يوجد فروق دالة احصـائية بين الفقرة رقم (3) ومحتو اهـا " يميل إلى الانطو ائية و البعد عن الأخرين" بين الذكور و الإناث من الأسر الكافلة في استجاباتهم لهذه العبارة. لا يوجد فروق دالة احصـائية بين الفقرة رقم (3) ومحتو اهـا " القدرة على فهم مشـاعر الأخرين تجاهـه." بين الذكور و الإناث من الأسر الكافلة في استجاباتهم لهذه العبارة. هكذا يتضـح في جميع العبار ات لا يوجد فروق ذات دلالة احصـائية وبـاقي العبار ات للمحور الأول (التو افق النفسي) وكذللك الدرجة الكلية. جدول (14) نتائج اختبار ت (T-Test) للفروق بين متوسطات استجابات أفراد عينة الدراسة نحو مستوى التوافق الاجتماعي للأيتام تعزي لمتغير الجنس ن=99

\begin{tabular}{|c|c|c|c|c|c|c|c|}
\hline \multicolumn{2}{|c|}{ مستوى الدلالة } & قيمة & الانحراف & المتوسط & 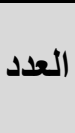 & 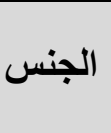 & 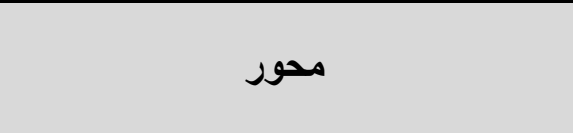 \\
\hline \multirow{2}{*}{ 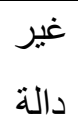 } & \multirow{2}{*}{0.654} & 0.735 & 1.160 & 3.333 & 51 & أنثى & \multirow{2}{*}{ يشبع احتباجاته دون أن يطلبها. } \\
\hline & & & 1.091 & 3.500 & 48 & ذكر & \\
\hline \multirow{2}{*}{ 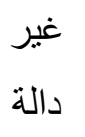 } & \multirow{2}{*}{0.513} & \multirow[t]{2}{*}{0.963} & 1.473 & 2.431 & 51 & أنثى & \multirow{2}{*}{ 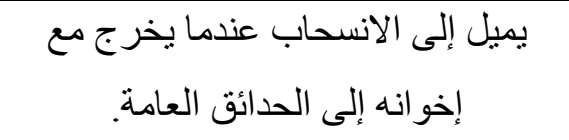 } \\
\hline & & & 1.383 & 2.708 & 48 & 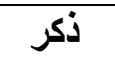 & \\
\hline \multirow{2}{*}{ 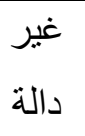 } & \multirow{2}{*}{0.018} & \multirow[t]{2}{*}{2.971} & 0.971 & 4.235 & 51 & أنثى & \multirow{2}{*}{ يكون صداقات تفاعلية مع الآخرين ويخلق } \\
\hline & & & 1.270 & 3.562 & 48 & ذكر & \\
\hline \multirow{2}{*}{ 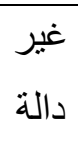 } & \multirow{2}{*}{0.014} & \multirow[t]{2}{*}{2.279} & 0.996 & 3.745 & 51 & أنثى & \multirow{2}{*}{ يشعر بجو من التفاهم خارج المنزل. } \\
\hline & & & 1.152 & 3.229 & 48 & 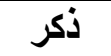 & \\
\hline \multirow{2}{*}{ 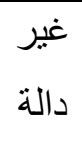 } & \multirow{2}{*}{0.095} & \multirow[t]{2}{*}{2.153} & 0.890 & 4.078 & 51 & أنثى & \multirow{2}{*}{ يمتللك قدرة عالية على فهم الأخرين داخل } \\
\hline & & & 1.84 & 3.625 & 48 & 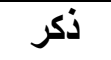 & \\
\hline \multirow{2}{*}{ 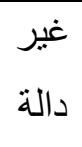 } & \multirow{2}{*}{0.248} & \multirow[t]{2}{*}{1.091} & 0.763 & 4.235 & 51 & أنثى & \multirow{2}{*}{ يتجنب إلى المشاركة مع إخوانه مع الأبناء } \\
\hline & & & 0.989 & 3.854 & 48 & ذكر & \\
\hline \multirow{2}{*}{ 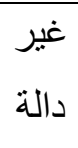 } & \multirow{2}{*}{0.662} & \multirow[t]{2}{*}{1.188} & 0.841 & 4.176 & 51 & أنثى & \multirow{2}{*}{ متكيف داخل المنزل و لا يقوم بأساليب } \\
\hline & & & 0.956 & 3.979 & 48 & ذكر & \\
\hline \multirow{2}{*}{ 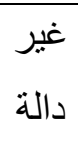 } & \multirow{2}{*}{0.968} & \multirow[t]{2}{*}{2.188} & 0.638 & 4.411 & 51 & أنثى & \multirow{2}{*}{ يتميز باكتساب مهار ات من أقرانه. } \\
\hline & & & 0.846 & 4.083 & 48 & 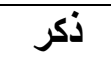 & \\
\hline \multirow{2}{*}{ 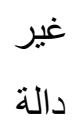 } & \multirow{2}{*}{0.778} & \multirow[b]{2}{*}{0.446} & 1.191 & 2.980 & 51 & أنثى & \multirow{2}{*}{ يصعب عليه الاستقلالية في أرائه مع } \\
\hline & & & 1.160 & 2.875 & 48 & 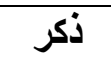 & \\
\hline
\end{tabular}




\begin{tabular}{|c|c|c|c|c|c|c|c|}
\hline \multicolumn{2}{|c|}{ مستوى الدلالة } & قيمة & الانحر اف & المتوسط المسبي & 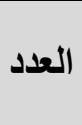 & الجنس & 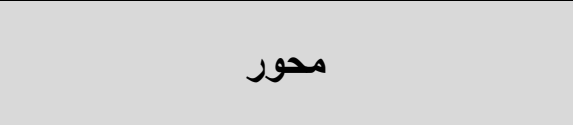 \\
\hline \multirow{2}{*}{ 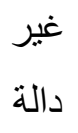 } & \multirow{2}{*}{0.696} & \multirow[t]{2}{*}{0.353} & 1.336 & 2.882 & 51 & أنثى & \multirow{2}{*}{ يحتاج إلى المزيد من الأمن الاجتماعي } \\
\hline & & & 1.406 & 2.979 & 48 & 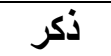 & \\
\hline \multirow{2}{*}{ غير } & \multirow{2}{*}{0.214} & \multirow[t]{2}{*}{0.724} & 1.250 & 2.274 & 51 & أنثى & \multirow{2}{*}{ الكذب سمة أساسية في جميع أقو اله. } \\
\hline & & & 1.076 & 2.104 & 48 & ذكر & \\
\hline \multirow{2}{*}{ 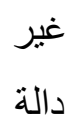 } & \multirow{2}{*}{0.086} & \multirow[t]{2}{*}{0.572} & 1.246 & 1.921 & 51 & أنثى & \multirow{2}{*}{ يقوم الطفل بسرقة زملائه داخل الفصل } \\
\hline & & & 0.988 & 1.791 & 48 & ذكر & \\
\hline \multirow{2}{*}{ غير } & \multirow{2}{*}{0.438} & \multirow[t]{2}{*}{0.148} & 1.253 & 2.431 & 51 & أنثى & \multirow{2}{*}{ يظهر عليه العناد والتمرد عندما بطلب } \\
\hline & & & 1.124 & 2.395 & 48 & 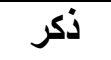 & \\
\hline \multirow{2}{*}{ 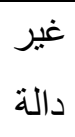 } & \multirow{2}{*}{0.085} & \multirow[t]{2}{*}{0.987} & 1.447 & 2.941 & 51 & أنثى & \multirow{2}{*}{ يبكي الطفل عندما يعلو الصوت في وجهه } \\
\hline & & & 1.236 & 3.208 & 48 & ذكر & \\
\hline \multirow{2}{*}{ غيز } & \multirow{2}{*}{0.766} & \multirow[t]{2}{*}{3.400} & 1,347 & 3.509 & 51 & أنثى & \multirow{2}{*}{ يميل في التفاعل للإناث أكثر من الذكور. } \\
\hline & & & 1.300 & 2.604 & 48 & 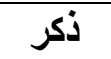 & \\
\hline \multirow{2}{*}{ غير } & \multirow{2}{*}{0.627} & \multirow[t]{2}{*}{1.679} & 9.671 & 47.431 & 51 & أنثى & \multirow{2}{*}{ الارجة الكلية } \\
\hline & & & 8.002 & 50.437 & 48 & ذكر & \\
\hline
\end{tabular}

يتضح من الجدول (14) يظهر في عبار ات المحور الأول (مشكلات التو افق الاجتماعي عدم وجود فروق ذات دلالة احصائية بين عبار ات المحور و الدرجة الكلية من حيث متغير الذكور و الإناث، وتظهر كالتالي:

- ـ ل ايوجد فروق دالة احصائية بين الفقرة رقم (1) ومحتو اها " يميل إلى الانسحاب عندما يخرج مـع إخو انه إلى الحدائق العامة" بين الذكور والإناث من الأسر الكافلة في استجاباتهم لهذه العبارة. لا يوجد فروق دالة احصائية بين الفقرة رقم (2) ومحتو اها " يكون صداقات تفاعلية مع الآخرين ويخلق جواً من المرح" بين الذكور والإناث من الأسر الكافلة في استجاباتهم لهذه العبارة.

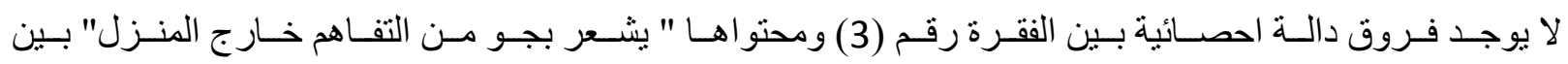
الذكور والإناث من الأسر الكافلة في استجاباتهم لهذه العبارة.

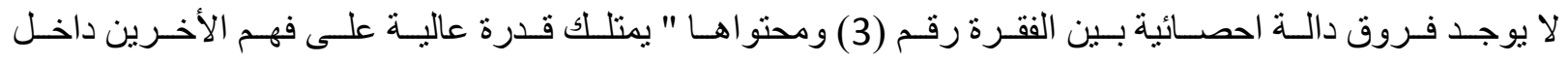
المنزل وخارجه" بين الذكور والإناث من الأسر الكافلة في استجاباتهم لهذه العبارة.

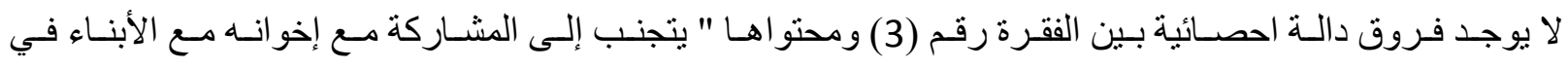
الأعمال المنزلية" بين الذكور و الإناث من الأسر الكافلة في استجاباتهم لهذه العبارة. 
هكذا يتضـح فـي جميـع العبـار ات لا يوجــــــروق ذات دلالـة احصـائية وبـاقي العبـار ات للمحـور الأول (التوافـق

النفس) وكذلك الدرجة الكلية.

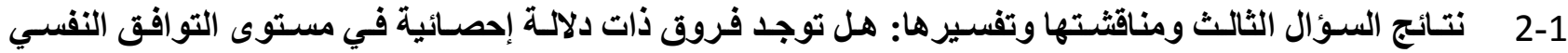

والاجتماعي لاى الأيتام ذوي الظروف الخاصة من وجهة نظر الأسر الكافلة تعزي لمستوى الدخل الأسري؟

لمعرفة ما إذا كانت هنالك فروق ذات دلالة إحصـائية بين وجهات نظر عينـة الدراسـة في تحديد الفروق في مستوى التو افق النفسي و الاجتماعي لدى الأيتام ذوي الظروف الخاصـة. تم استخدام اختبار كروسكال و الاس (Kruskal Wallis) بديلاً عن اختبار تحليل التباين الأحادي One Way Anova)، وذلك لعدم التكافؤ بين فئات متغير الدر اسـة كما يتضـح في الجدول رقم

جدول (15) نتائج اختبار كروسكال والاس (Kruskal Wallis) للفروق بين متوسطات استجابات أفراد عينة الدراسة نحو الفروق في مستوى التوافق النفسي والاجتماعي لاى الأيتام تعزي لمستوى الاخل الأسري ن=99

\begin{tabular}{|c|c|c|c|c|c|}
\hline \multicolumn{2}{|c|}{ مستوى الدلالة } & متوسط & العدد العد & مستوى الاخل الأسري & محور - \\
\hline \multirow{4}{*}{ 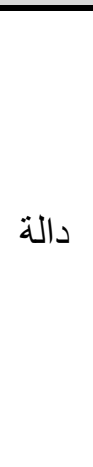 } & \multirow{4}{*}{0.000} & 53.94 & 34 & أقل من 5000 ربال & \multirow{4}{*}{ التوافق التفسي للأيتام ذوي الظروف } \\
\hline & & 56.90 & 35 & من 5000 ربال إلى 10000 & \\
\hline & & 41.33 & 18 & من 10000 ريال إلى 15000 & \\
\hline & & 31.71 & 12 & أكثر دن 15000 ربال & \\
\hline \multirow{4}{*}{ 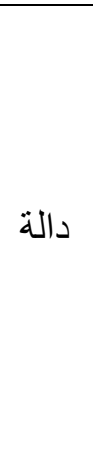 } & \multirow{4}{*}{0.000} & 56.32 & 34 & أقل من 5000 ربال & \multirow{4}{*}{ التوافق الاجتماعي للأيتام ذوي الظروف } \\
\hline & & 53.86 & 35 & من 5000 ربال إلى 10000 & \\
\hline & & 43.36 & 18 & من 10000 ريال إلى 15000 & \\
\hline & & 30.79 & 12 & أكثر من 15000 ربال & \\
\hline \multirow{3}{*}{ دالة ل } & \multirow{3}{*}{0.000} & 56.22 & 34 & أقل من 5000 ربال & \multirow{3}{*}{ الارجة الكلية } \\
\hline & & 56.03 & 35 & من 5000 ربال إلى 10000 & \\
\hline & & 40.94 & 18 & من 10000 ربال إلى 15000 & \\
\hline
\end{tabular}




\begin{tabular}{|c|c|c|c|c|}
\hline مستوى الدلالة & متوسط & 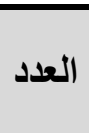 & مستوى الدخل الأسري & محور \\
\hline & & & ربال & \\
\hline & 28.38 & 12 & أكثر من 15000 ربال & \\
\hline
\end{tabular}

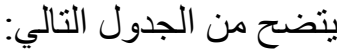
أو لاً في المحور الأول: مشكلات التو افق النفسي للأيتام ذوي الظروف الخاصـة يتضـح وجود فروق ذات دلالة احصـائية بين الأسر من حيث مستوى الدخل الأسري حيث تباينت الأسر السعودية في مستوى الدخل الأسري فمنهم من تراوح دخله أقل من 5000 وشغلت النسبة الأكبر في مشكلات التو افق النفسي ومن أكثر من ذلك في مستوى الدخل للأسر الكافلـة لكي تكون سبباً في مشكلات التو افق النفسي للأطفال الأيتام عن الأسر الكافلة لهم بسبب عدم قدرتهم على كفالتهم مادياً. وجاء المحور الثاني: مشكلات التو اقق الاجتماعي للأطفال الأينام ذات فروق بين الأسر من حيث مستوى الدخل الأسري من حيث الزيادة و النقصان على حسب ما ظهر في متغير مستوى الدخل المادي للأسرة وكذللك الدرجة الكلية جاءت ذات دلالة إحصائية بين الأسر الكافلة

للطفل اليتيم ذوي الظروف الخاصة. ويمكن استشهاد نتائج الدر اسة من خلال أدبيات الدر اسة و الدر اسات السابقة، حيث نجد أن على سبيل المثال المعوقات الجسمية للدى الأطفال تكون عائقاً وتوجد مـن المشكلات النفسية لدى الاسـر الكافلة مـن خـلال معانـاتهم في فترة التربيـة أو كفالتهم للأطفال، كذلك من المعوقات الاجتماعيـة نقص الصداقة وعدم قدرة الأطفال على كسب الأصدقاء في مواجهة السخرية أو التهكم مع الكبار وهو ما ذكره (الدسوقي، 1985). كما وضح (الخو الدة، 2020) بعض من المشكلات للأطفال المحرومين من الرعاية الأسرية يعانون من مشكلات عديدة مثل فقدان الحب و الحنان و التقدير و الأمن والاستقر ار النفسي، ومن هذه المشكلات التالي: المشكلات الصحية وتمثل في حاجات الطفل و غذائه المناسب وتختلف من حيث الحاجات و التنوع حسب نموه بشكل طبيعي و إن عدم إثباع هذه الحاجات أو إثباعها بشكل خاطئ أو نقص يؤدي إلى العديد من المشكلات الصحية المختلفة بالتعرض لبعض الأمر اض المختلفة، المشكلات النفسية وتتمثل في الطريقة التي يتعامل بها الطفل في سنو اته الأولى وهي دوره وتكوينه النفسي فاسلوب التربية الذي يثير مشاعر الخوف و انعدام الأمن في مواقف التفاعل يترتب عليه تعرض الطفل لمشكلات نفسية عديدة ومن أبرز ها القلق و الخوف و الانطو اءو الخجل، بالإضافة إلى المشكلات الاجنماعيـة تعرض الكثير من الأطفال خلال مر احل نمو هم لمشكلات اجنماعية عديدة ومختلفة ذات عو امل متباينة و آثار ها بالنسبة للطفل. ومن الدر اسات السابقة التي تؤيد ذلك، الدر اسات التالية: در اسة العمور(2015) حيث هدفت الدر اسة إلى المشكلات الانفعالية و الاجتماعية لدى الأيتـام المر اهقين وتوصلت الدراسـة إلى وجود فروق دالة احصائيا في مدى انتشـار المشكلات الانفعالية والاجتماعية بـاختلاف الجنس ولصـالح الذكور، ودر اسـة العطار (2019) هدفت للتعرف على أكثر من المشكلات السلوكية انتشار اً لدى الأطفال الأيتام حيث توصلت الدراسـة إلى إظهار عدم وجود فروق دالة احصائية بين الذكور والإناث في المشكلات السلوكية ولم تظهر فروق في متغير الحرمـان، وفي در اسة العتيبي (2021) هدفت إلى التعرف على مدى فاعلية برنامج إرشادي انتقائي لتتمية التو افق النفسي و الإجتمـاعي لدى 
الايتـام وتوصلت الدر اسـة إلى تنميـة التو افق النفسي والاجتمـاعي حيث وجدت فروق ذات دلالة احصـائية بين المجمو عنين التجريبية و الضابطة، بينما في محور العو امل الاجتماعية والاقتصادية المؤثرة على التكيف أظهرت در اسـة القديري(2019) الكثف عن أثر العو امل الاجتماعية والاقتصادية على التكيف الاجتماعي لأسر الأيتام واعتمدت الدراسة على العينة العثوائية وتوصلت الدر اسة إلى أن بعض العو امل الاجتماعية وخاصة عمر الأم والحالة الاجتماعية لها ليس لله علاقة بمعدل التكيف لهـي

الاجتماعي.

5. النتائج والتوصيات والمقترحات.

تمهيد:

تتاول هذا الفصل أهم نتائجها وتوصياتها ومقترحاتها التي تم التوصل إليها في ضوء تساؤلات الدر اسة و أهدافها.

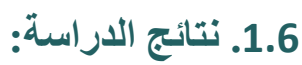
تم فبه تحليل البيانات ونتائج الدر اسة، ومناقتنتها وتفسير ها. حيث تمت الإجابة على أسئلة الدر اسة من خلال العرض التفصيلي لكل مجال من مجالاتها على حدة، وعرض النتائج مدعمة بالجداول الإحصائية مع التعليق على نتائج البيانات ومحاولة تفسير ها وربطها بالدر اسات السابقة. يمكن عرض مناقثنة نتائج الدر اسة من خلال ما تم الحصول عليه من نتائج حيث نجد السؤال الأول ونص على التعرف على " مـا مستوى التو افق النفسي والاجتمـاعي للى الأيتام ذوي الظروف الخاصـة من وجهة نظر الأسر الكافلـة التابعين لإدارة الأسر الكافلة بالمدينة المنورة"، توصلت النتائج: - - ارتفاع المتوسطات لعدد من العبار ات للمحور الأول (التو افق النفسي) و التي تمثلت على الترتيب كالتالي: 1- 1 - شعور الطفل بالدفء والحماية والانتماء. 2- الثقة بالنفس كبيرة و عالية بأفر اد الأسرة. 3- مر اعاة لمشاعر الأخرين. 4- صدوره لمشاعر مقبولة ناحية إخو انه داخل المنزل. 5- قدرته على فهم مشاعر الأخرين تجاهه. 6- حاجته للمزيد من الأمن النفسي داخل الأسرة. أما عن العبارات التي حازت على انخفاض في المحور الأول، التالي: 1. صدوره لأساليب عدو انية داخل المنزل بشكل مستمر. 2. شعوره بعدم الرغبة في تناول الطعام لفترات طويلة. 3. ميله إلى الانطو ائية والبعد عن الأخرين. 4. ل لديه الثعور بالتهديد المستمر. 5. احساسه بالنبذ و عدم رغبة الأخرين به. بينما جاء المحور الثاني (التو افق الاجتماعي) عبار اته المتمنلة في الارتفاع، كالتالي: 1- - تميز الطفل باكتسابه لمهار ات مع أقر انه.

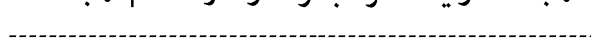


2- قدرته على التكيف داخل المنزل و لا يقوم بأساليب عدو انية. 3- جاذبيته إلى المشاركة مع إخو انه من الأبناء في الأعمال المنزلية. 4- تكوينه صداقات تفاعلية مع الأخرين وخلقه جواً من المرح. 5- شعوره بجو من التفاهم خارج المنزل. أما عن العبارات التي حازت على انخفاض في المحور الثاني، التالي: 1- بكاءه عندما يعلو الصوت في وجهه. 2- صعوبة الاستقلالية في أر ائه مع الآخرين. 3- حاجته إلى المزيد من الأمن الاجنماعي. 4- ميله إلى الانسحاب عندما يخرج مع اخوانه في الحدائق.

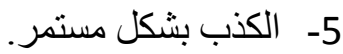
6- - قبامه لسرقه زملائه داخل الفصل الدراسي. كما يمكن عرض مناقثة نتائج السؤال الثاني من خـلال مـا تم الحصول عليه من نتائج حيث نجد السؤ ال الثناني نص على التعرف على " اختلاف مستوى التوافق النفسي والاجنماعي للأيتام ذوي الظروف الخاصة من وجهة نظر الأسر الكافلة لهم تعزي للنوع (ذكور - إناث)"، توصلت النتائج : عدم وجود فروق دالة احصائية بين عبار ات المحورين (التو افق النفسي والاجتماعي) لمشكلات الأطفال الأيتام ذوي الظروف الخاصة من وجهة نظر الأسر الكافلة لهم تعزي للنوع (ذكور - إناث) ويرجع ذللك إلى أن الأسر الكافلة سواء كانو ا يكفلون أطفال ذكور أو إناث لا يؤثر على طبيعة المشاكل نتيجة لأن المشكلة التي يمر بها الطفل في تللك المرحلة لا تختلف تبعاً للنوع و هو ما ذكرته العديد من الدر اسات السابقة.

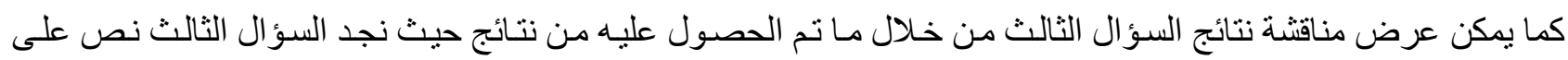
التعرف على " وجود فروق ذات دلالة احصائية في مستوى التو افق النفسي والاجتمـاعي لدى الأيتام ذوي الظروف الخاصـة من وجهة نظر الأسر الكافلة تعزي للمستوى الاقتصادي"، توصلت النتائج: وجود فروق دالة احصائية بين محوري الدر اسة (مشكلات التو افق النفسي و الاجتماعي) وفقا لمتغير مسنوى الدخل الأسري ويمكن تحليل الباحث لذلك بأن الدخل المادي لله عامل أساسي في تلبية الاحتياجات البيولوجية وتحقيق الأمن كمـا أثـار ماسلو بأن الأمن يمكن تحقيقه من خـلال تحقيق الذات واشباع الاحتياجـات البيولوجية و الأساسية للطفل، وهذا يظهر بـأن معدلات الدخل المنخفضة تزداد لدى الأسر الكافلة حيث تر اوح أقل من 5000 ربال وهذا يكون سبباً في تواجد الكثير من المشكلات النفسية والاجتماعية للأسرة التي تؤثر على الطفل وتربيته.

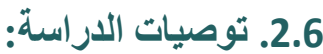

بناء على نتائج الاراسة توصل الباحث إلى عدد من التوصيات: 1. تنمية شعور الطفل بالدفء و الحماية والانتماء. 2. تنمية الثقة بالنفس للطفل اليتيم داخل الأسر الكافلة. 3. تتمية حاجته للمزيد من الأمن النفسي داخل الأسرة. 


\section{4. صدوره لأساليب عدو انية داخل المنزل بشكل مستمر. 5. مشاركته في مزيد من الأنشطة لخفض حدة الانطو ائية و البعد عن الأخرين.

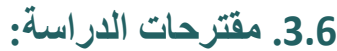 \\ 1. أثر خفض مشكلات التوافق النفسي على الصحة النفسية لاى الأطفال الأيتام ذوي الظروف الخاصـة. 2. الخدمات الانتقالية للأطفال الأيتام بإدارة الاسر الكافلة بالمدينة المنورة: دراسة تحليلية. 3. تقييم المشكلات النفسية والاجتماعية لدى الأطفال الأبتام ذوي الظروف الخاصة بالمملكة العربية السعودية. 4. در اسة تقويمية للأثار النفسية والاجتماعية الناتجة عن كفالة الطفل اليتيم بالمدينة المنورة. 5. الطلاق و أثاره النفسية والاجتماعية للأطفال الأيتام بالمدينة المنورة.}

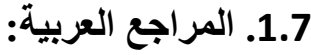

أبو الحسن، نبيل محمد (2015). المعوقات التي تواجه الأخصائيين الاجتمـاعيين في الدمج الاجتمـاعي للأينام ذوي الظروف الخاصـة: در اسـة مطبقـة على الأخصـائيين الاجتمـاعبين بمؤسسـات رعايـة الأيتـام بمكـة المكرمـة، مجلـة الخدمـة

$$
\text { الاجتماعية، الجمعية المصرية للأخصائيين الاجتماعيين، 54، مصر. }
$$

أحمد، ايناس جابر (2011). حقوق الطفل في القانون الدولي، مجلـة البحوث القانونية والاقتصادية، 34 (20)، كلية الحقوق جامعة المنوفية، مصر.

الأشقر، اسامة عمر (2009). حقوق الطفل اللقيط من المنظور الفقهي. مجلة الثربعة والدراسات الإسلامبة، (77). الحسن، إحسان (2005). النظريات الاجتماعية الدتقدمة، دار و ائل للنشر ، عمان، الأردن. حموين، فاطمة الز هر اء (2016). الحرمان العاطفي عند الطفل اليتيم، مجلة العلوم الإنسانية والاجتماعية، عدد27، الجزائر. الخالدي، أديب (2001). الصحة النفسية، الدار العربية للنشر والتوزيع، المكتبة الجامعية، غريانـ للييا. الخالدي، عطا الله (2009). صحة نفسية وعلاقتها بالتكيف والتو (فق. ط1، دار صفاء للنشر و التوزيع، عمان. الخو الدة، صالح سالم (2020). فاعلية برنامج إرشادي يستند إلى الاتجاه الإنساني في خفض أزمة الهوية وتحسين المعنى لاى الأيتام في الأردن، رسالة دكتوراه، جامعة العلوم الإسلامية العالمية. السدحان، عبدا ناصر (2003). أطفال بلا أسر، مكتبة العبيكان، الرياض. عامر ، محمد السيد (2000). التـخل المهني للخدمة الاجتماعية لمو اجهة بعض مشكلات الأطفال في المؤسسـات الإيوائية، بحث منشور ، المؤتعر العلمي الحادي عشر، كلية الخدمة الاجتماعية، جامعة القاهرة. عبد الرحمن، فاطمة الزهر اء (2018). دور الإخصائي الاجتماعية لتنمية القيم لدى جماعات الأطفال الأيتام، رسالة ماجستبر، كلية الخدمة الاجتماعية، جامعة أسيوط. عبد الــعم، إيمـان محمد (2020). در اسـة تقييميـة لدور مؤسسـات الرعايـة الاجتماعيـة في تحقيق الأمـن الأسـري للأيتـام الملتحقين بها، مجلة دراسات في الخدمة الاجتماعية والعلوم الانسانية، 52 (1)، 230-268. 
عثمان، فاروق السيد (2005). القلق وإدارة الضنوط النفسية، ط1، دار الفكر العربي، القاهرة. العطار، يوسف محمد (2019). المشكلات السلوكية لاى الأطفال الأيتام من وجهة نظر المشرفات في ضوء بعض المتغيرات في مركز رعاية الطفولة بمحافظة مسقط، مجلة العلوم التربوية والنفسية، 6 (3)، 165-179. العلوان، خالد حسين (2020). خصائص أرباب الأسر الحاضنة المتنبئة بأنماط تنشئتهم للأطفال مجهولي النسب في المجتمع الأردني، دراسات العلوم الإنسانبة والاجتماعية، 1 (47)، 740-754.

العمور ، أحمد زايد (2015). المشكلات الانفعالية و الاجتماعية لدى الأيتام المر اهقين في قضـاء بئر السبع، رسالة ماجستبر، كلية العلوم التربوية و النفسية.

القديري، أملـ بنت حمـاد (2019). العو امل الاجتماعيـة والاقتصـادية المؤثرة على التكيف الاجتمـاعي لأسـر الأيتـام دراسـة ميدانية مطبقة على عينة من أسر الأيتام التابعة للجمعية الخيرة لرعاية الأينام، مجلة العلوم العربية والإنسانية، 13 $.1005-961 ،(2)$

كفافي، علاء الدين (2010). الصحة النفسية،ط2، القاهرة. كـلاب، نسـرين (2014). اثـباع الحاجـات النفسية و علاقتهـا بقلق المستقبل لدى المـر اهقين الأيتـام المقيمسين في المؤسسـات الإيو ائية و غير الإيو ائية بمحافظات غزة، رسالة ماجستبر ، الجامعة الإسلامية، غزة.

محمد، عرفه محمد (2018). التو افق النفسي و التحصيل الدر اسي وعلاقتهما ببعض المتغير ات لدى الأيتام في مرحلة الطفولة الوسطى (6-9 سـوات): در اسـة على عينـة مـن الأيتـام بمرحلـة الأسـاس بمدينـة وضـواحي الرصيرص، رسـالة

$$
\text { ماجستير ، جامعة أم درمان الاسلامية. }
$$

محمد، محمد جاسم (2004). مشكلات الصحة النفسية أمراضها - وعلاجها، دار الثقافة، عمان، الأردن.

مليجي، أمال عبد السميع باظه (2003). الأطفال و المر/هقون المعرضون للخطر، القاهرة، مكتبة الأنجلو المصرية.

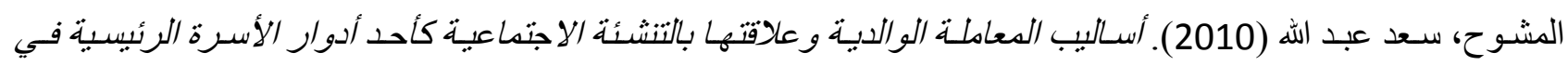

$$
\text { المجتمع السعودي، جامعة الملك سعود، الرياض. }
$$

المشيخي، غالب بن محمد (2009). قلق المستقبل و علاقته بكل من فاعلية الذات ومستوى الطموح، رسالة دكتوراه غير

$$
\text { منشورة جامعة أم القرى. }
$$

ميخائيل، نيفين ميخائيل (2020). دور الجدعيات الألية في رعاية الأطفال الأبتام بدصر، جامعة عين شمس، (28)، 209276.

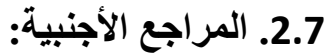

Carr ‘A. (2009). "The effectiveness of family therapy and systemic interventions for adult focused problems." Journal of family therapy 31(1): 46-74.

Minuchin ‘R. ،et al. (1974). "The use of structural family therapy in the treatment of intractable asthma." American Journal of Psychiatry 131(5): 535-540. 
المجلة الدولية لنشر البحوث والدراسات

International Journal of Research and Studies Publishing ISSN: 2709-7064
المجلد الثالث - الإصدار الثامن والعشرون تأريخ الإصدار: 20 فبراير 2022 م

Minuchin ‘S. ret al. (2013). Psychosomatic families ،Harvard University Press.

Rutter D. R . and. Jessop ‘D. C (2003). "Adherence to asthma medication: the role of illness representations." Psychology and Health 18(5): 595-612.

Skinner ‘D. cet al. (2004). "Defining orphaned and vulnerable children (Social Aspects Of HIV/AIDS And Health Research Programme rOccasional Paper 2)." Cape Town: HSRC Publishers.

Tania 'T. and K. Carroll (2003). Addressing the educational needs of orphans and vulnerable children ‘Save the Children rand ActionAid International.

Doi: doi.org/10.52133/ijrsp.v3.28.14 